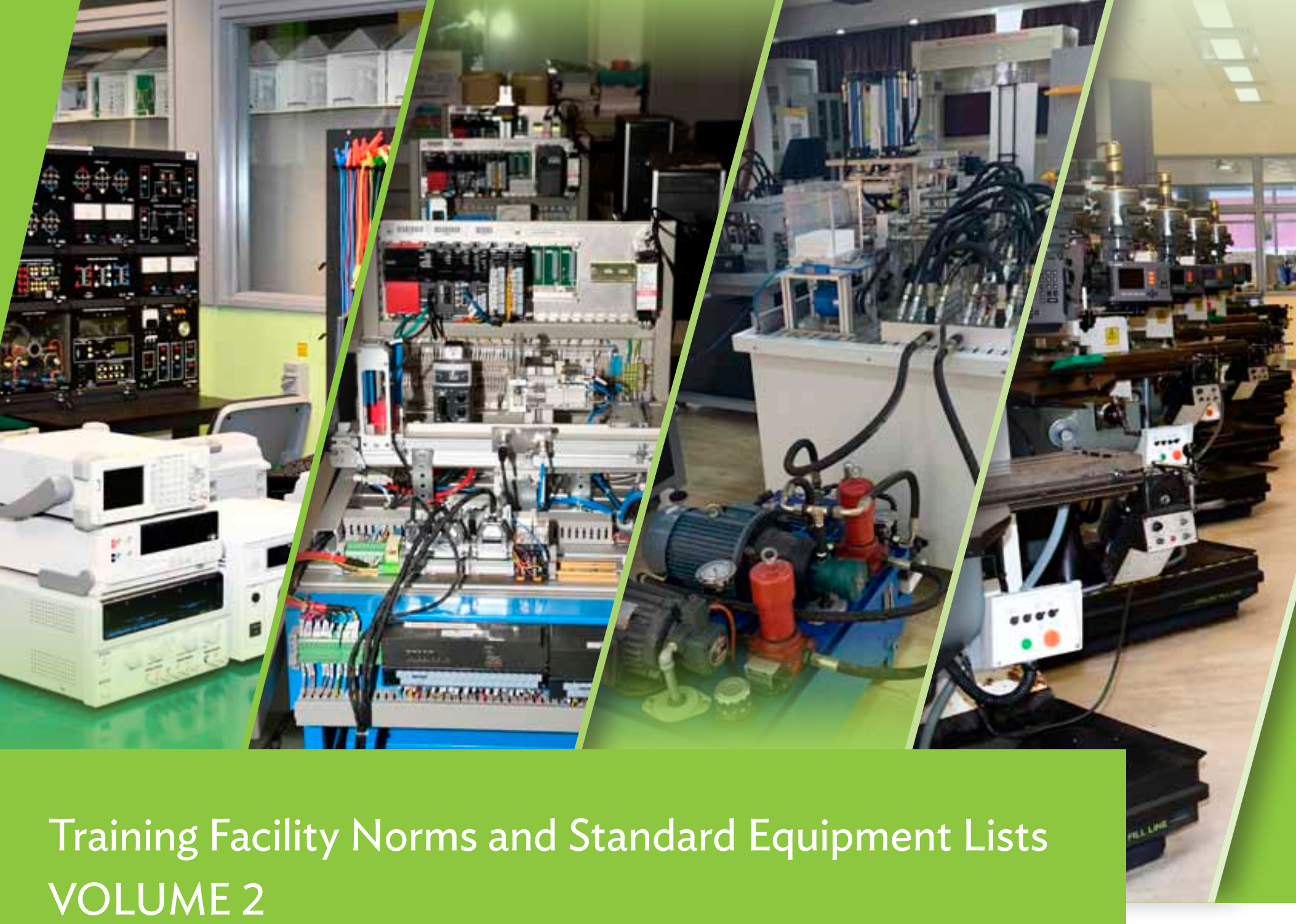

MECHATRONICS

TECHNOLOGY

Fook Yen Chong and Raymond Tay

NOVEMBER 2019 

Training Facility Norms and Standard Equipment Lists VOLUME 2

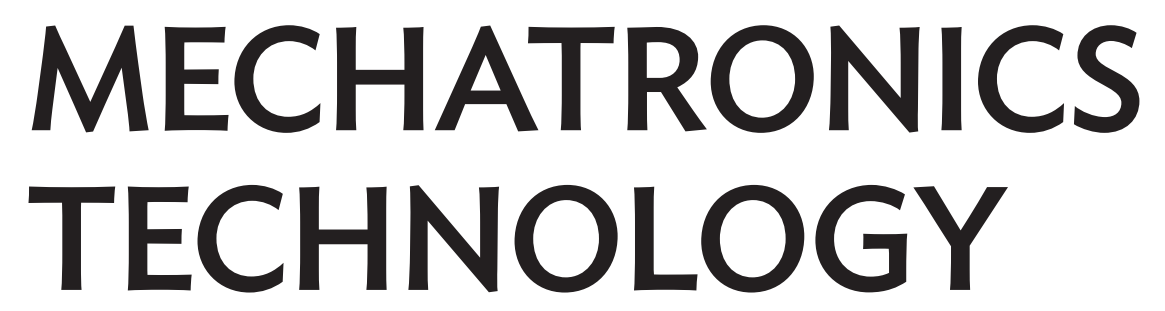

Fook Yen Chong and Raymond Tay

NOVEMBER 2019 
(C) 2019 Asian Development Bank 6 ADB Avenue, Mandaluyong City, 1550 Metro Manila, Philippines

Tel +632 8632 4444; Fax +63286362444

www.adb.org

Some rights reserved. Published in 2019.

ISBN 978-92-9261-828-5 (print), 978-92-9261-829-2 (electronic)

Publication Stock No. TCS190491-2

DOI: http://dx.doi.org/10.22617/TCS190491-2

The views expressed in this publication are those of the authors and do not necessarily reflect the views and policies of the Asian Development Bank (ADB) or its Board of Governors or the governments they represent.

ADB does not guarantee the accuracy of the data included in this publication and accepts no responsibility for any consequence of their use. The mention of specific companies or products of manufacturers does not imply that they are endorsed or recommended by ADB in preference to others of a similar nature that are not mentioned.

By making any designation of or reference to a particular territory or geographic area, or by using the term "country" in this document, $A D B$ does not intend to make any judgments as to the legal or other status of any territory or area.

This work is available under the Creative Commons Attribution 3.0 IGO license (CC BY 3.0 IGO)

https://creativecommons.org/licenses/by/3.o/igo/. By using the content of this publication, you agree to be bound by the terms of this license. For attribution, translations, adaptations, and permissions, please read the provisions and terms of use at https://www.adb.org/terms-use\#openaccess.

This CC license does not apply to non-ADB copyright materials in this publication. If the material is attributed to another source, please contact the copyright owner or publisher of that source for permission to reproduce it. $\mathrm{ADB}$ cannot be held liable for any claims that arise as a result of your use of the material.

Please contact pubsmarketing@adb.org if you have questions or comments with respect to content, or if you wish to obtain copyright permission for your intended use that does not fall within these terms, or for permission to use the ADB logo.

Corrigenda to ADB publications may be found at http://www.adb.org/publications/corrigenda.

Note:

In this publication, “\$” refers to United States dollars.

Photos by Nanyang Polytechnic International and ITE Education Services in Singapore.

Cover design by Joe Mark Ganaban. 


\section{CONTENTS}

TABLES AND FIGURES

ACKNOWLEDGMENTS

ABBREVIATIONS

EXECUTIVE SUMMARY

iv

$\mathrm{v}$

vi

vii

1. INTRODUCTION

2. BASIC ELECTRICAL AND ELECTRONICS TRAINING LABORATORY

\subsection{Basic Electrical Laboratory}

2.1.1 Training Facility Norms

2.1.2 Standard Equipment List

2.1.3 Sample Photos for Electrical Workstation

2.2 Electronics Laboratory

2.2.1 Training Facility Norms

2.2.2 Standard Equipment List

2.2.3 Sample Photo for Electronics Laboratory

3. HYDRAULICS AND PNEUMATIC TRAINING FACILITIES 17

$\begin{array}{lll}3.1 & \text { Hydraulics Laboratory } & 18\end{array}$

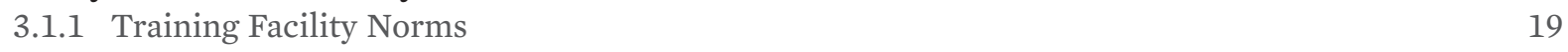

3.1.2 Standard Equipment List 21

3.1.3 Sample Photo for Hydraulic Laboratory 24

$\begin{array}{lll}3.2 & \text { Pneumatic Laboratory } & 25\end{array}$

3.2.1 Training Facility Norms $\quad 26$

3.2.2 Standard Equipment List 28

3.2.3 Sample Photos for Pneumatic Laboratory 31

4. MECHATRONICS TRAINING FACILITIES 32

4.1.1 Training Facility Norms $\quad 33$

$\begin{array}{lll}\text { 4.1.2 Standard Equipment List } & 35\end{array}$

4.1.3 Sample Photos for Mechatronics Laboratory 39

5. PROGRAMMABLE LOGIC CONTROLLER, SENSOR, AND VISION LABORATORY 40

5.1.1 Training Facility Norms $\quad 41$

$\begin{array}{lll}\text { 5.1.2 Standard Equipment List } & 43\end{array}$

5.1.3 Sample Photos of Programmable Logic Controller, Sensor, and Vision Laboratory 46

$\begin{array}{ll}\text { 6. INDUSTRIAL PROJECT LABORATORY } & 47\end{array}$

$\begin{array}{lll}\text { 6.1.1 Training Facility Norms } & 48\end{array}$

$\begin{array}{ll}\text { 6.1.2 Standard Equipment List } & 50\end{array}$

6.1.3 Sample Photos for Industrial Project Laboratory 56 


\section{TABLES AND FIGURES}

\section{Tables}

$1 \quad$ Floor Area Requirement for Basic Electrical Technology Laboratory $\quad 7$

2 Laboratory and/or Workshop for Basic Electrical Technology Laboratory 8

3 Basic Electrical Technology Workshop Equipment Specification 9

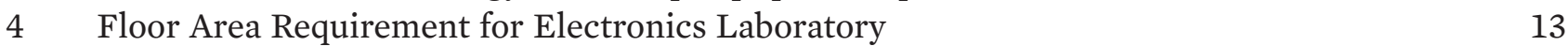

$5 \quad$ Laboratory and/or Workshop for Electronics Laboratory $\quad 14$

$6 \quad$ Electronics Laboratory Equipment Specification $\quad 15$

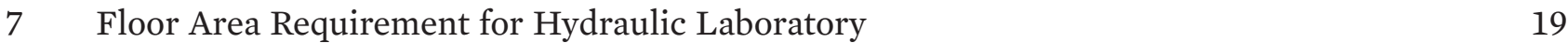

8 Laboratory and/or Workshop for Hydraulic Laboratory 20

9 Hydraulic Laboratory Specification $\quad 21$

10 Floor Area Requirement for Pneumatic Laboratory $\quad 26$

11 Laboratory and/or Workshop for Pneumatic Laboratory $\quad 27$

12 Pneumatic Laboratory Equipment Specification $\quad 28$

13 Floor Area Requirement for Modular/Flexible Manufacturing System Laboratory 33

14 Laboratory and/or Workshop for Modular/Flexible Manufacturing System Laboratory 34

15 Modular/Flexible Manufacturing System Laboratory Equipment Specification 35

16 Floor Area Requirement for Programmable Logic Controller, Sensor, and Vision Laboratory

17 Laboratory and/or Workshop for Programmable Logic Controller, Sensor, and Vision Laboratory

18 Programmable Logic Controller, Sensor, and Vision Laboratory Equipment Specification

19 Floor Area Requirement for Industrial Project Laboratory

20 Laboratory and/or Workshop for Industrial Project Laboratory 49

21 Industrial Project Laboratory Equipment Specification

\section{Figures}

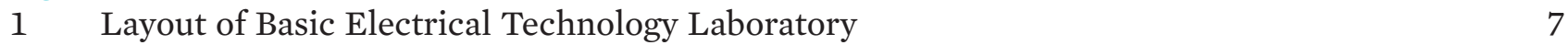

2 Layout of Electronics Laboratory $r$

3 Layout of Hydraulic Laboratory $r$

4 Layout of Pneumatic Laboratory $\quad 26$

$5 \quad$ Layout of Modular Manufacturing System Laboratory $\quad 33$

6 Layout of Programmable Logic Controller, Sensor, and Vision Laboratory 41

7 Layout of Industrial Project Laboratory $\quad 48$ 


\section{ACKNOWLEDGMENTS}

he Asian Development Bank (ADB) has ramped up lending to the technical and vocational education and training (TVET) sector in recent years. TVET institutions are instrumental in strengthening skills and entrepreneurial capabilities of young people. Improving access, quality, equity, and relevance of TVET is therefore critical to meeting the aspirations of the youth and industry needs. Education and skills development are often unable to keep up with the pace of technological changes, and TVET systems need to adopt new technologies much faster under the fourth industrial revolution. Recent technological developments in the area of artificial intelligence, the Internet of Things, big data analytics, and machine learning have huge implications for TVET. Constant updating of TVET facilities, instructor competencies, and the training system needs to be accelerated.

This ADB technical specification reference guide aims to provide guidance to TVET policymakers and practitioners in the adoption of good practices for the design of training facility norms and standard equipment lists based on industry standards. These specifications are indicative, and should be further contextualized based on the actual needs of the TVET institutions. This volume is the second in a series of technical specification reference guides that cover four strategic trades in the field of manufacturing: (i) precision engineering or machining, (ii) mechatronics technology, (iii) mechanical technology, and (iv) electrical technology.

Precision machining uses cutting tools to produce parts and components widely used in automotive parts and component manufacturing, aerospace parts frames, components manufacturing, and die or mold making. Mechatronics technology combines mechanical, electronics, computer, and electrical technology to support automation in manufacturing processes. Mechanical technology is the application of engineering and scientific principles to ensure the smooth operation and efficient use of machinery and mechanical equipment. Electrical technology is the application of science and engineering principles to install, operate, maintain, and repair electrical instruments and wiring in residential, commercial, and industrial settings.

Fook Yen Chong, Social Sector Specialist, Human and Social Development Division (SAHS), South Asia Department, ADB, and Raymond Tay, ADB consultant in Singapore, prepared this volume. The peer reviewers were Shamit Chakravarti, Principal Social Sector Specialist, Human and Social Development Division, Southeast Asia Department; and Francis Arcenal, TVET Consultant in the Philippines. Ryotaro Hayashi, SAHS provided valuable comments, Alfredo P. Garcia and Ma. Cristina S. Bardos, SAHS provided administrative assistance. The authors are also grateful for the cooperation of Nanyang Polytechnic International and ITE Education Services in Singapore for taking photos of their training facilities at their campus.

\section{Sungsup Ra}

Director, Human and Social Development Division

South Asia Department, ADB 


\section{ABBREVIATIONS}

$\mathrm{ADB}$

ILO

PLC

TVET

UNESCO

Asian Development Bank

International Labour Organization

programmable logic controller

technical and vocational education and training

United Nations Educational, Scientific and Cultural Organization 


\section{EXECUTIVE SUMMARY}

T

he design and implementation of technical and vocational education and training (TVET) projects require good guidance to ensure that the project moves forward in the right direction. Currently, many developing Asian countries face challenges, such as time pressure to deliver project outcomes and results, building capacity quickly, making appropriate policy changes, and providing sustainable resources and results.

This reference guide on the indicative norms for the design of training facilities and standard equipment lists has been prepared to support developing member countries in delivering better and faster reforms in TVET. It provides examples and guidance to users in making decisions about ideal technical specifications when establishing training facilities for mechatronics technology training programs. It also identifies equipment specifications aligned with current industry standards.

Ideally, training facility norms and equipment lists should be based on existing curriculum standards defining depth of skills and specific pedagogic requirements. To mitigate possible curriculum discrepancies, the authors adopted a basic principle that the training facility norms and standard equipment lists should be adaptable for postsecondary TVET courses to train entrylevel machinists for work in developed and/or newly industrialized countries. The training facility norms and standard equipment lists are aligned to a well-established machining workshop. Care has been taken to consult with industry, and to benchmark against reputable TVET institutions. While this reference guide cannot substitute for up-to-date and industry-aligned curricula and pedagogic requirements, it focuses on critical underlying parameters such as space, safety, student-to-equipment ratio, circulation area, and adequacy of teaching facilities.

The authors also adopted the principle of equipment-to-student ratio at 1:1, 1:2 or 1:4 based on best practices in different institutions. Depending on the available budget and how well teachers can adapt to different pedagogical approaches, the equipment-to-student ratio needs to be configured differently.

This reference provides broad guidance and should not be mechanically applied to different settings. Users are strongly encouraged to customize these indicative specifications and guidelines according to industry needs, education requirements, budgetary availability, local regulatory requirements (safety and building), and curriculum standards. It is necessary to focus on industrycurriculum alignment within the limitations of budget and resources. Predefining teacher-student and student-equipment ratios as well as appointing the right experts to plan and design the training facilities are also crucial. 


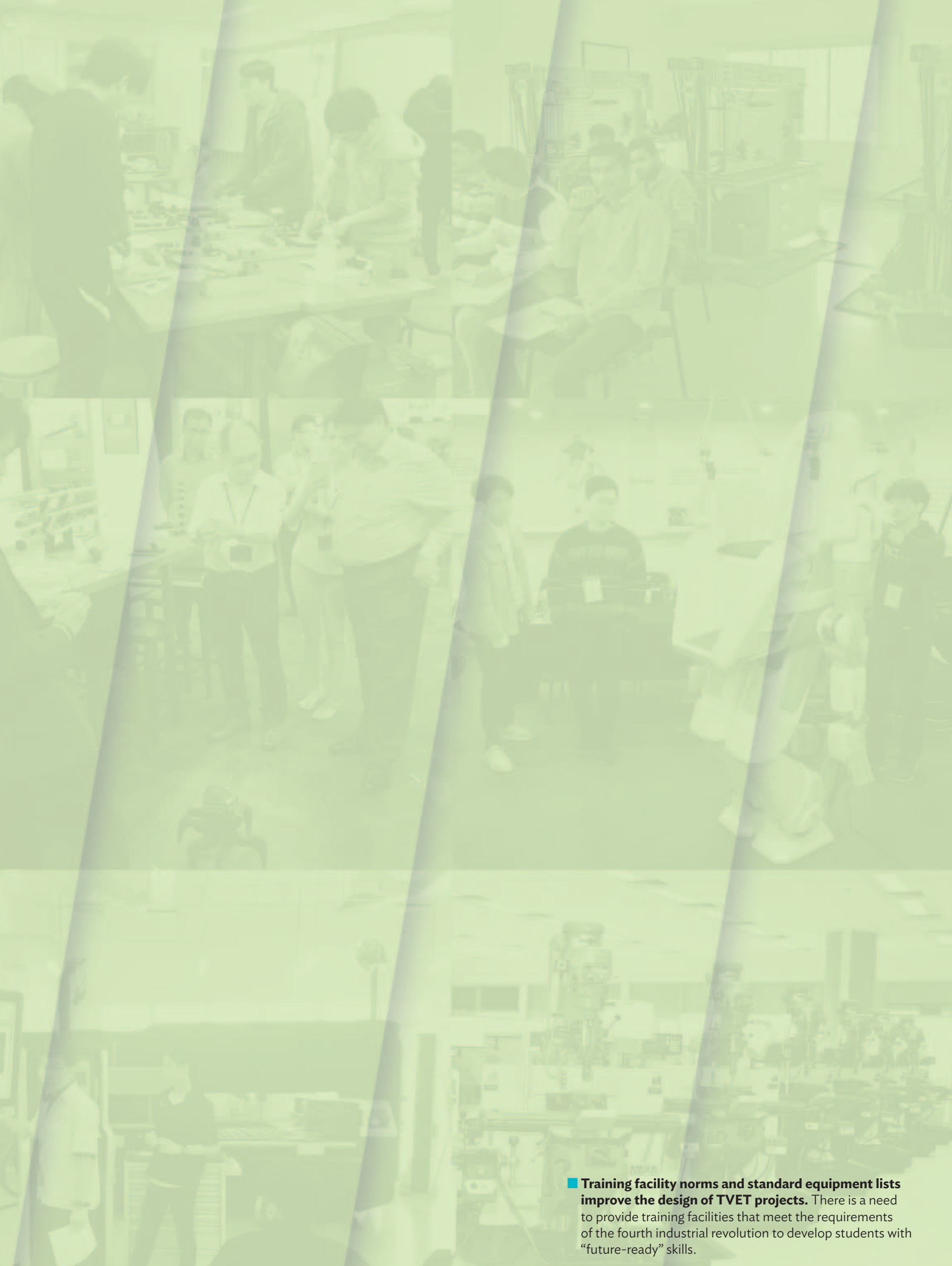




\section{INTRODUCTION}

uring 2009-2011 and 2015-2017, the Asian Development Bank (ADB) increased total sovereign lending to the education sector in the Asia and Pacific region by $\$ 1$ billion from $\$ 1.4$ billion to $\$ 2.4$ billion. Within this sector, the share of lending for technical and vocational education and training (TVET) increased from $12.8 \%$ to $57.5 \%$, a reflection of the growing emphasis being given by developing member countries to skills development. Many ongoing and proposed pipeline projects have substantial civil works involving upgrading and construction of training facilities and procurement of goods, such as training equipment. However, improvement of the technical specifications can be further defined and incorporated to ensure that training facilities meet both curriculum and industry requirements.

Often, TVET executing and implementing agencies in developing countries lack the technical expertise to design quality training facilities. They may spend considerable time in preparing training equipment specifications without knowledge of the latest industry requirements, and inadvertently procure inferior quality equipment that do not meet the latest curriculum or industry standards.

ADB has initiated the development of training facility norms and standard equipment lists to provide indicative guidance. These are meant to be references for executing and implementing agencies as they plan the construction of training infrastructure and procurement of training equipment. This reference guide will be useful in designing new TVET projects particularly in the mechatronics technology.

\section{RATIONALE FOR DEVELOPING TRAINING FACILITY NORMS AND STANDARD EQUIPMENT LISTS}

Training facility norms and standard equipment lists will improve the design of TVET projects.

Many TVET buildings have been designed and built like general education school buildings. However, it is very important for TVET training facilities to be designed in line with curriculums that reflect industry standards and requirements. Pedagogical, safety, and health requirements should be defined properly and incorporated into the design of the facilities. Electrical loading, floor loading, and space requirements require proper computation and measurement. The ratios of students to equipment, and teacher to students, should also be defined based on industry requirements.

Architects and construction companies should be adequately familiar with the training and equipment requirements of the specific training programs when designing TVET infrastructure. Often, the expectation is that they will incorporate the appropriate technical parameters and specifications as required by the TVET institutions. It is therefore important that executing and 
implementing agencies, architects, and contractors work together. In the planning, design, and construction of fit-for-purpose TVET infrastructure, architects and contractors should obtain appropriate inputs and instructions from executing and implementing agencies.

Many trade teachers in developing Asian countries, particularly those working for public training centers, are not actively engaged with industry or do not currently possess in-depth working knowledge and experience in industries. At the beginning of a TVET reform project, they may not be sufficiently familiar with the latest technologies and industry practices and processes to provide the detailed inputs. In addition, when new trade areas are introduced, institutions often lack the expertise to develop the technical specifications to procure training equipment and machines.

The concept of developing training facility norms and standard equipment lists for TVET is not necessarily new, but it needs to be updated for emerging trades. For instance, the United Nations Educational, Scientific and Cultural Organization (UNESCO) and International Labour Organization (ILO) developed guidance for developing TVET workshops in the 1970s and 1980s (ILO 1978, ILO 1986, Pitanilabut 1979, UNESCO 1979, UNESCO 1989). However, these were not updated regularly. The National Institute of Building Sciences in the United States, including the National Clearinghouse for Educational Facilities, provided important design considerations for training facilities in 2017 (see National Institute of Building Sciences 2017), but this useful information needs to be elaborated on for emerging trades in developing Asia.

With the fourth industrial revolution, it becomes critical for TVET institutes to realign their facilities to keep pace with the changing technology needs of industry. Schwab (2016) argues that the fourth industrial revolution or Industry 4.0 is different from the first three industrial revolutions in terms of the speed, scope, magnitude, and interconnectedness of the change. Technological advances in different areas are building on and amplifying each other in a fusion of technologies that will transform the world of work. ${ }^{1}$

There is a need to provide training facilities to develop students with "future-ready" skills by meeting the requirements of the fourth industrial revolution. This series of training facility norms and standard equipment lists provides requirements to suit current industry needs and advocates the incorporation of new technologies.

\section{MECHATRONICS TECHNOLOGY}

This volume covers mechatronics technology. ${ }^{2}$ The mechatronics technology field of study provides students with multi-disciplinary and/or inter-disciplinary skills and knowledge (mechanical, electrical, electronics, and information technology) in installing, setting up, commissioning, operating, maintaining, and servicing industrial automated production equipment, line, and systems. It provides an advanced skillset to manage process control in production and quality control. Mechatronics technology is a key field of study for supporting modern industrialization, such as food manufacturing, electronics, electrical, and automotive assembly.

1 At the World Economic Forum, Schwab (2016, p. 7) considers Industry 4.0 as a "confluence of emerging technology breakthroughs, covering wide-ranging fields such as artificial intelligence, robotics, Internet of Things, autonomous vehicles, three dimensional printing, nanotechnology, biotechnology, materials science, energy storage, quantum computing, and mobile phones to name a few," which are changing the way people live, work, interact, produce, and consume.

2 The other volumes are precision engineering or machining, mechanical technology, and electrical technology, which are also developed as reference guides of training facility norms and standard equipment lists. 
The recent proliferation of Industry 4.0 is closely related to mechatronics technology. Sensor technology, robotics, Internet of Things, big data, and data analytics are key advanced technology aspects that are already integrated with mechatronics technology. The industry trend is moving toward automated production facilities that are Industry 4.0-enriched.

Possible occupations associated with mechatronics technology are automation technician, automated equipment maintenance technician, mechatronics technician, robotic technician, etc.

\section{TARGETED READERS AND HOW TO USE THE TRAINING FACILITY NORMS AND STANDARD EQUIPMENT LISTS}

The training facility norms and standard equipment lists will be useful guides for TVET planners, administrators, and instructors; as well as for architects, design and supervision consultants, and civil work contractors. They would also be helpful to nontechnical staff engaged in TVET project design and development partner institutions. More specifically, training facility norms and standard equipment lists will help expedite the design of future TVET projects involving new construction or upgrading of training facilities. Government officials involved in designing TVET projects need to understand the estimated space, floor loading, lighting, electrical loading, and other building services required for training facilities. The reference guides will also provide a good benchmark and can further improve training facilities.

\section{METHODOLOGIES}

Five considerations directed the development of the training facility norms and standard equipment lists. First, these training facility norms and standard equipment lists are aligned with the post-secondary TVET standards of industrialized economies. Second, training facility norms and standard equipment lists are aligned with industry norms for entry-level skilled positions. Third, reputable TVET institutions in the People's Republic of China, Malaysia, Singapore, and other countries were studied as reference points in developing these norms and standard equipment lists. Fourth, the experience of task teams who have worked in TVET institutions and implemented multiple projects in establishing training facilities and procuring training equipment contributed tremendously to shaping the training facility norms and standard equipment lists. Fifth, for basic tools and conventional equipment, the task team proposed a ratio of equipment and tools to student at 1:1; and for advanced sophisticated training equipment, 1:2 or 1:4.

In addition, the task team considered the emerging needs of the fourth industrial revolution, and incorporated some advanced technology features already available in equipment and machines used by industry. A good example is the proposal for Internet of Things-enabled or enriched training equipment that can (i) track utilization of training equipment, (ii) monitor student progress on practical skills learning, (iii) support individual student learning plans through big data and data analytics, and (iv) support greater use of formative rather than summative assessment. 


\section{LIMITATIONS}

Several considerations should be noted in using the training facility norms and standard equipment lists. First and foremost, these reference guides should be adapted to the curriculum. Second, they should be contextualized in each unique setting based on budget, space (including loading capacities and access), industry demand, and institutional capacity. Third, the estimated costs are based on standard industry grades, and could vary depending on specifications, and operation and maintenance requirements. The cost estimate is based on 2018 prices, which need to be updated when designing a specific project. Fourth, the reference guides are intended for entry-level skills, and the details need to be adjusted for advanced skills. For instance, as discussed earlier, the task team proposed equipment-student ratios of 1:2 or 1:4 for advanced tools and conventional equipment. ${ }^{3}$

\section{STRUCTURE OF THE REPORT}

Section 1 discusses the rationale for developing training facility norms and standard equipment lists in the field of mechatronics technology. Mechatronics technology is largely divided into three areas: (i) electrical and electronics training facilities; (ii) hydraulics and pneumatic training facilities; and (iii) mechatronics training facilities (modular manufacturing system, programmable logic controller, sensor and vision laboratory). Each technical section includes training facility norms (such as floor plan layouts and floor area requirements) followed by standard equipment lists and pictures of key equipment.

Section 2 describes electrical and electronics training facilities by electrical laboratory (section 2.1) as well as electronics laboratory (section 2.2). Section 3 introduces hydraulics and pneumatic training facilities by hydraulics laboratory (section 3.1) and pneumatic laboratory (section 3.2). Section 4 explains the mechatronics training facility requirements on modular and/or flexible manufacturing system. Section 5 describes programmable logic controller, sensor, and vision laboratory and Section 6 explains industrial project laboratory.

3 Details are available from the references or upon request from Fook Yen Chong, Social Sector Specialist, ADB (fchong@adb.org). 


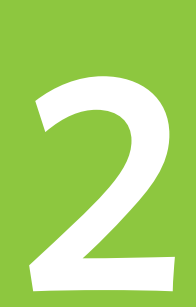

\section{BASIC ELECTRICAL}

AND ELECTRONICS

TRAINING LABORATORY
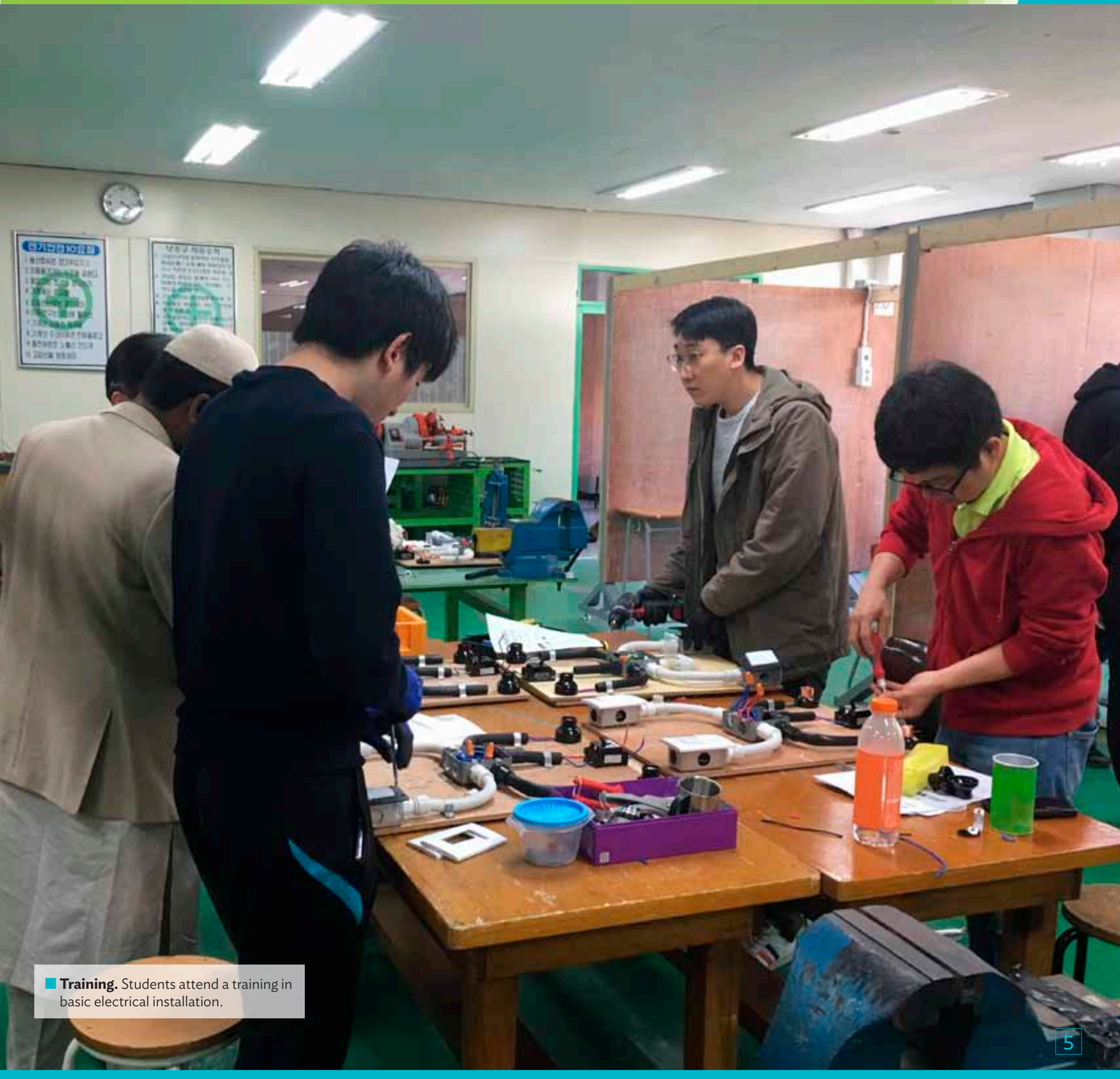


\subsection{BASIC ELECTRICAL LABORATORY}

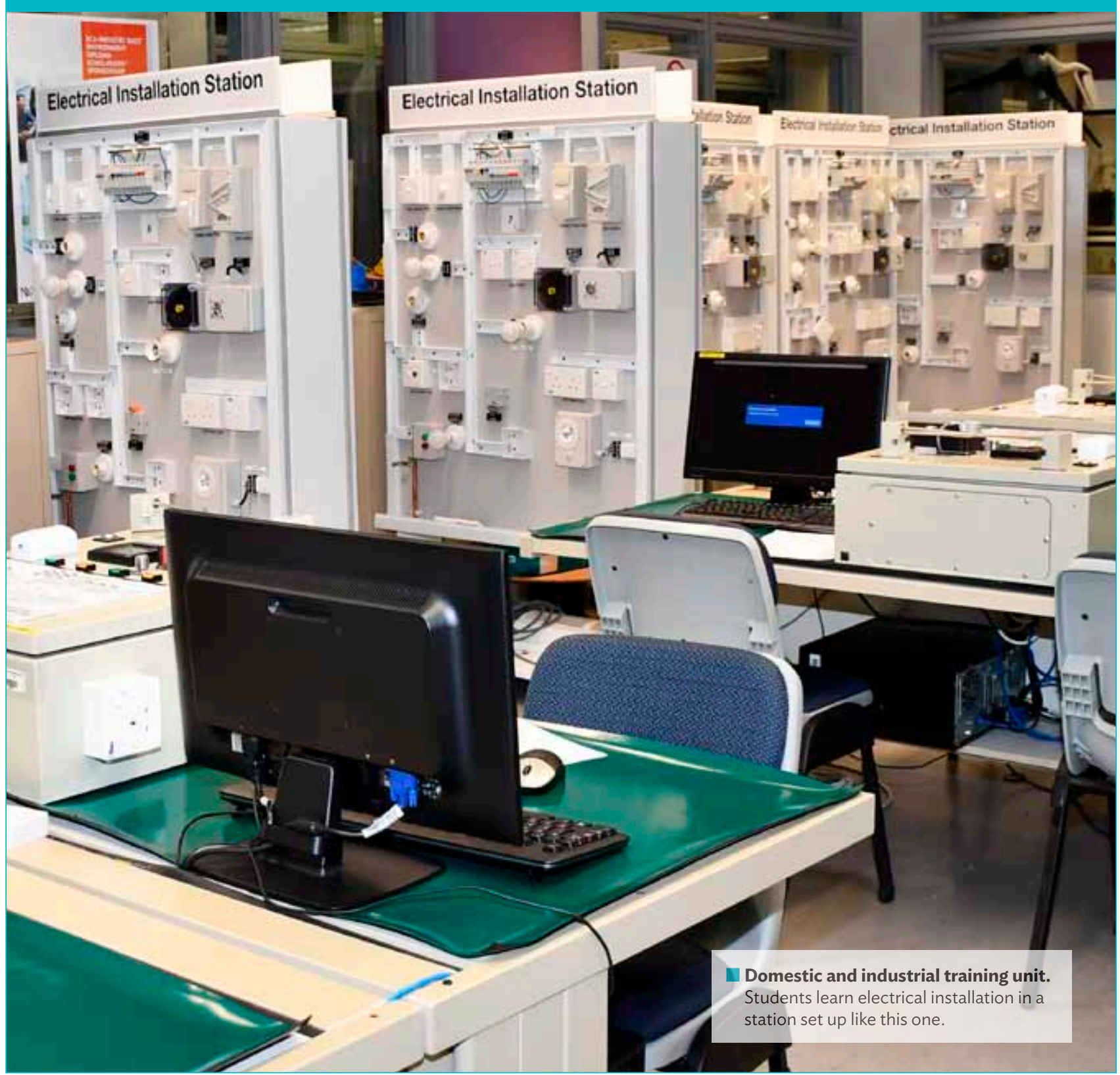




\subsubsection{Training Facility Norms}

\section{A. WORKSHOP FLOOR PLAN LAYOUT AND SIZE}

Figure 1: Layout of Basic Electrical Technology Laboratory

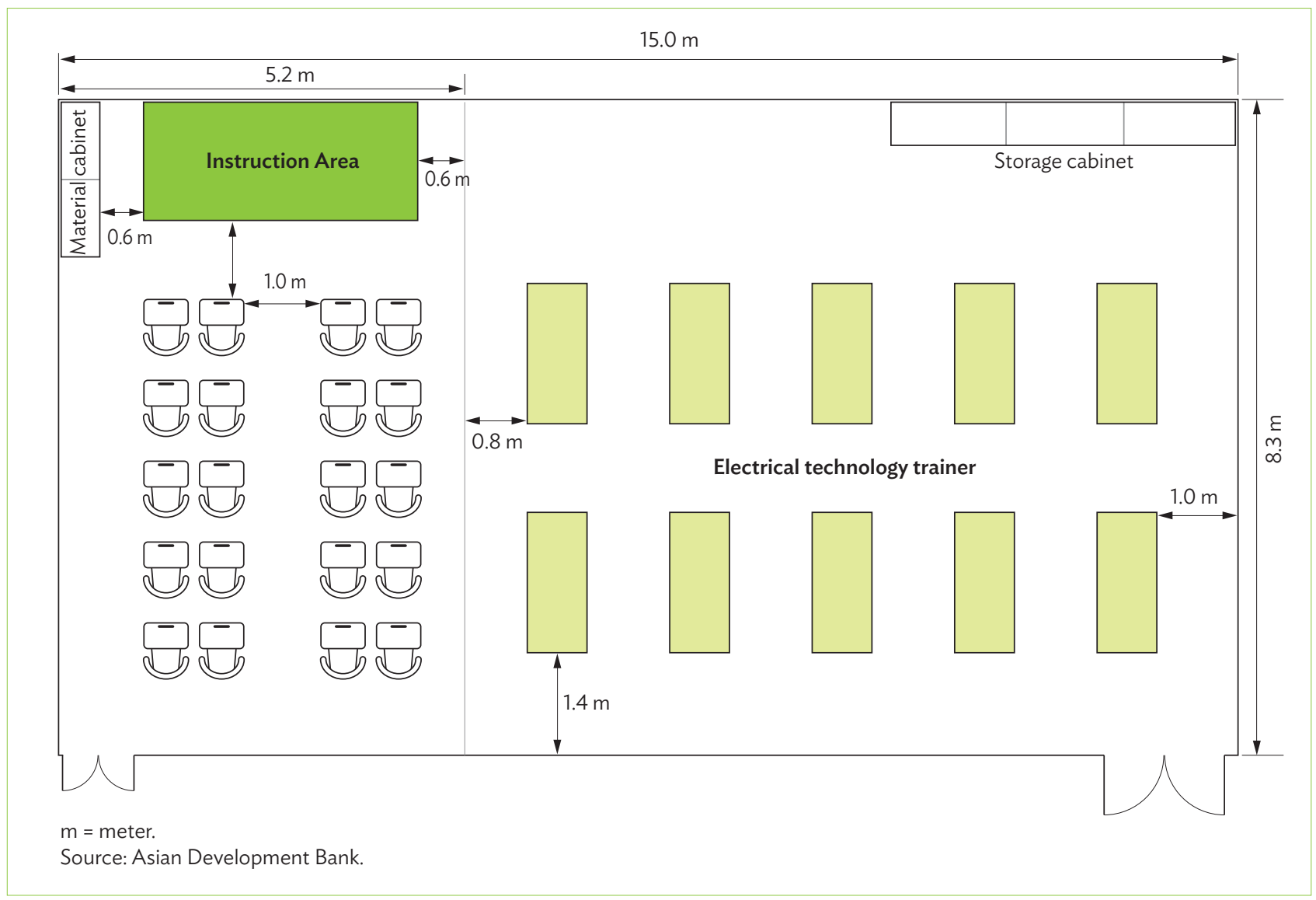

Table 1: Floor Area Requirement for Basic Electrical Technology Laboratory

\begin{tabular}{|c|c|c|c|c|}
\hline $\mathbf{S} / \mathbf{N}$ & Item & Quantity & Dimensions & Area \\
\hline 1 & Practical learning area & 1 & $9.85 \mathrm{~m} \times 8.3 \mathrm{~m}$ & $82 \mathrm{~m}^{2}$ \\
\hline 2 & Electrical technology trainer units & 10 & - & - \\
\hline 3 & Storage cabinet & 3 & - & - \\
\hline 4 & Theory learning area & 1 & $5.17 \mathrm{~m} \times 8.3 \mathrm{~m}$ & $43 \mathrm{~m}^{2}$ \\
\hline 5 & Teacher's table and chair set & 1 & - & - \\
\hline 6 & Students' chairs and table & 20 & - & - \\
\hline 7 & Ceiling projector & 1 & - & - \\
\hline 8 & Projector screen & 1 & - & - \\
\hline 9 & Whiteboard & 1 & - & - \\
\hline 10 & First aid kit & 1 & - & - \\
\hline 11 & Fire extinguisher & 2 & - & - \\
\hline 12 & Storage cabinet & 2 & - & - \\
\hline
\end{tabular}

$-=$ not applicable, $m=$ meter, $\mathrm{m}^{2}=$ square meter.

Source: Asian Development Bank. 


\section{B. TECHNICAL SPECIFICATIONS FOR THE WORKSHOP}

Table 2: Laboratory and/or Workshop for Basic Electrical Technology Laboratory

\begin{tabular}{|c|c|}
\hline \multicolumn{2}{|c|}{ Name of the Laboratory and/or Workshop BASIC ELECTRICAL TECHNOLOGY LABORATORY } \\
\hline Proposed Student Enrollment Size & Iment Size \\
\hline Applicable Field of Usage & MECHANICAL TECHNOLOGY, MECHATRONICS TECHNOLOGY \\
\hline Parameter & Remarks \\
\hline $\begin{array}{l}\text { Size of Laboratory } \\
\text { and/or Workshop }\end{array}$ & $\mathbf{1 5} \mathrm{m} \times \mathbf{8 . 3} \mathrm{m} \times \mathbf{4} \mathbf{m}$ (length $\times$ width $\times$ height) \\
\hline $\begin{array}{l}\text { Electrical Loading } \\
\text { Requirement }\end{array}$ & $\begin{array}{l}\text { Two } 16 \mathrm{~A} \text { twin socket electrical outlet should be provided for each computer } \\
1216 \mathrm{~A} \text { electrical socket outlet should be provided each for general use in the } \\
\text { practical area and theory area } \\
\text { All electrical installation should comply with local regulations } \\
\text { Two emergency stop-buttons should be provided }\end{array}$ \\
\hline $\begin{array}{l}\text { Floor Loading } \\
\text { Requirement }\end{array}$ & $350 \mathrm{~kg} / \mathrm{m}^{2}$ \\
\hline $\begin{array}{l}\text { Lighting Requirement } \\
\text { (Lumen) }\end{array}$ & $\begin{array}{l}\text { Standard ceiling flourescent lightings at } 25 \mathrm{~W} / \mathrm{m}^{2} \\
\text { Emergency lights }\end{array}$ \\
\hline Flooring Requirement & $\begin{array}{l}\text { Raised flooring to facilitate wire cabling from below floor } \\
\text { Vinyl composition to reduce dust and improve electrical insulation }\end{array}$ \\
\hline $\begin{array}{l}\text { Location of Laboratory } \\
\text { and/or Workshop } \\
\text { (Floor) }\end{array}$ & Any floor \\
\hline $\begin{array}{l}\text { Laboratory and/or } \\
\text { Workshop Climatic } \\
\text { Condition }\end{array}$ & Air-conditioned \\
\hline $\begin{array}{l}\text { Building Safety Code } \\
\text { Requirement }\end{array}$ & Comply with national safety code requirements \\
\hline Door Width & At least $1.5 \mathrm{~m}$ wide \\
\hline First Aid Requirement & Adhering to building safety code \\
\hline $\begin{array}{l}\text { Storage Area } \\
\text { Requirement }\end{array}$ & One storage cabinet \\
\hline $\begin{array}{l}\text { Built-in Furniture } \\
\text { Requirement }\end{array}$ & Not applicable \\
\hline
\end{tabular}




\title{
2.1.2 Standard Equipment List
}

Table 3: Basic Electrical Technology Workshop Equipment Specification

\author{
Name of the Laboratory and/or Workshop BASIC ELECTRICAL TECHNOLOGY LABORATORY \\ Proposed Student Enrollment Size \\ 20 \\ Applicable Field of Usage \\ MECHATRONICS, ELECTRICAL, AUTOMOTIVE
}

S/N Name of Item $\quad$ Description of Item $\quad$ Quantity $\quad$ Remarks

A Training Equipment and/or Machine: $\$ 150,000$

Electrical Fully assembled electrical control panel includes the Technology Trainer following:

Push-button - Four push-buttons. A green, yellow, and blue momentary push-button and a red maintained mushroom button. Each button has two normally open contacts and two normally closed contacts. The normally open contacts are colorcoded green and the normally closed contacts are color coded red on the back of the trainer.

Selector switch 2-position - Two 2-position selector switches. It should have an open contact on each selector switch that closes when you turn the switch to the right (clockwise).

Selector switch 3-position - Two 3-position selector switches. There is a normally open contact for both the left and right position of the selector switch.

Lights - Four lights colored green, yellow, red, and blue.

Analog potentiometer and gauge - 10K

potentiometer and a 4 to $20 \mathrm{~mA}$ analog gauge.

Contactor relay - One contactor or relay that is an open style. It is a double-pole double-throw, which means it has two sets of contacts with both normally open and normally closed positions.

AC drive - AC inverter drive takes 220 VAC singlephase in and creates 240 VAC 3-phase out so this trainer can be used to learn about 3-phase power yet plugs into a standard wall outlet.

24V DC power supply - 24V DC 50-watt switching power supply. The trainer should be designed for all switches, lights, relay or contactor, and even the heater to be powered by $24 \mathrm{~V} \mathrm{DC}$ to make it safer.

3-phase motor and/or fan - 3-phase fan. It along with the AC drive allows for 3-phase principles to be taught when only 220 VAC wall outlet power is available.

Heater and thermocouple - 24 V DC heater and type $\mathrm{J}$ thermocouple. The preceding relay or contactor can be used to switch the heater on and off

\section{0 units}


Table 3 continued

\section{S/N Name of Item}

\section{Description of Item}

Quantity

Remarks

Thermocouple to 4 to $20 \mathrm{~mA}$ converter

Terminal blocks

Programmable logic controller - CPU with 16 I/O's

Control panel types and mounting techniques covers:

metallic non-metallic (insulated)

direct mounting on insulated panels

rear connections

DIN mounted switchgear

strapped harness wiring use of duct to support and

channel wiring clearances

Labelling and numbering covers:

cable labelling or identification

component labelling or identification use of terminal

strips to assist fault finding

Component layout covers:

wiring and schematic diagrams

placement or layout of power circuit devices and

components

placement or layout of control circuit devices and

components

Interconnecting plugs and sockets

Choice of switchgear and control gear covers:

voltage ratings

current ratings

overload and fuse settings

number of operations

Other considerations include:

earthing of panels

size of power and control circuit conductors

effect of high current devices on electromagnetic

components or programmable logic controllers

effect on electronic components of other devices

Trainers' Training should be provided

\begin{tabular}{|c|c|c|c|}
\hline B & Tools & & \\
\hline & Set of pliers & 10 sets \\
\hline & & Set of screw drivers & 10 sets \\
\hline & & Set of wire markers & 10 sets \\
\hline & & Wire strippers & 10 sets \\
\hline & & Digital multi-meter & 10 sets \\
\hline & & Wire crimpers & 10 sets \\
\hline & & Clamp ammeter & 10 units \\
\hline & & Mobile tool trolley & 10 units \\
\hline & & Plastic cable tray $1 \mathrm{~m} \times 1.5^{\prime \prime} \times 1.5 ”$ & 20 pieces \\
\hline \multirow[t]{6}{*}{ C } & Furniture & & \\
\hline & & Table and chair for the trainer & 1 sets \\
\hline & & Students' tables and chairs & 20 sets \\
\hline & & Mobile whiteboard, $1,000 \mathrm{~mm} \times 1,500 \mathrm{~mm}$ & 1 unit \\
\hline & & Screen & 1 unit \\
\hline & & Projector (liquid crystal display) & 1 unit \\
\hline
\end{tabular}

$\mathrm{A}=$ ampere, $\mathrm{AC}=$ alternating current, $\mathrm{DC}=$ direct current, $\mathrm{DIN}=$ Deutsches Institut fur Normung (German Institute for Standardization), $\mathrm{I} / \mathrm{O}=$ input/output, $\mathrm{K}=$ shorthand for $1,000 \mathrm{ohms}, \mathrm{mA}=$ milliampere, $\mathrm{mm}=$ millimeter, $\mathrm{VAC}=$ voltage alternating current, $\mathrm{VDC}=$ voltage direct current. 


\subsubsection{Sample Photos for Electrical Workstation}

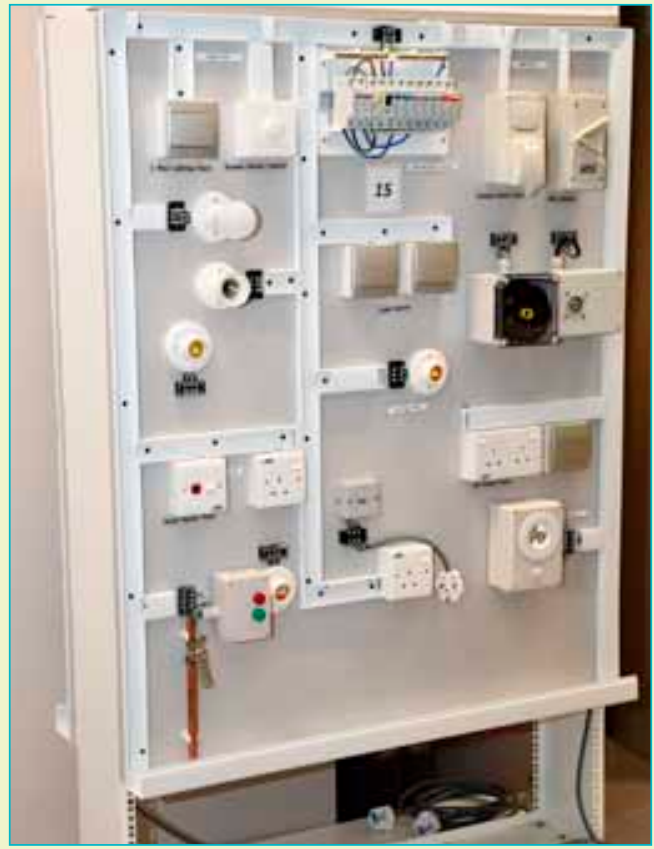

Basic electrical laboratory. Photo shows a close-up shot of a domestic electrical training workstation.

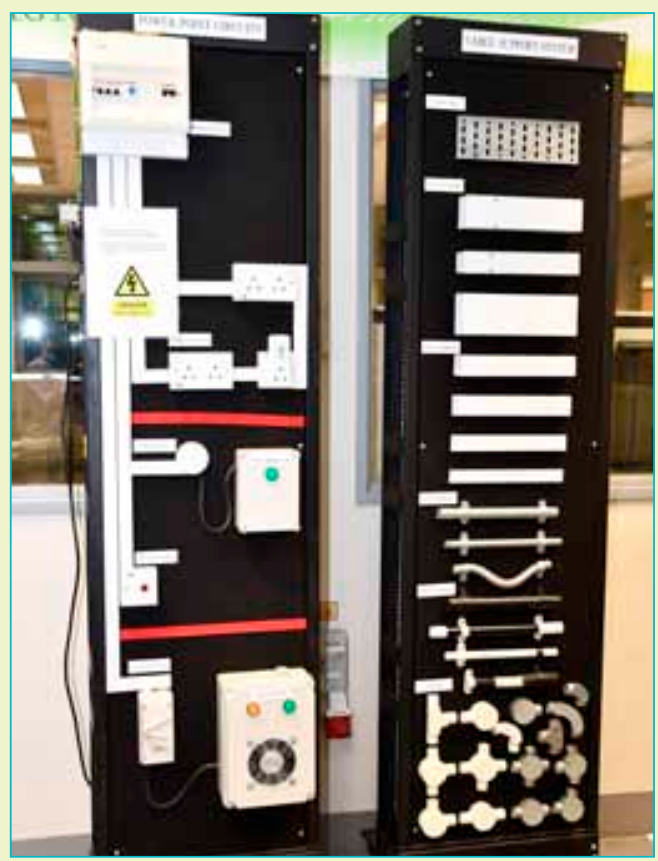

Industrial electrical training workstation. Photo shows a basic electrical laboratory training set-up for industry application.

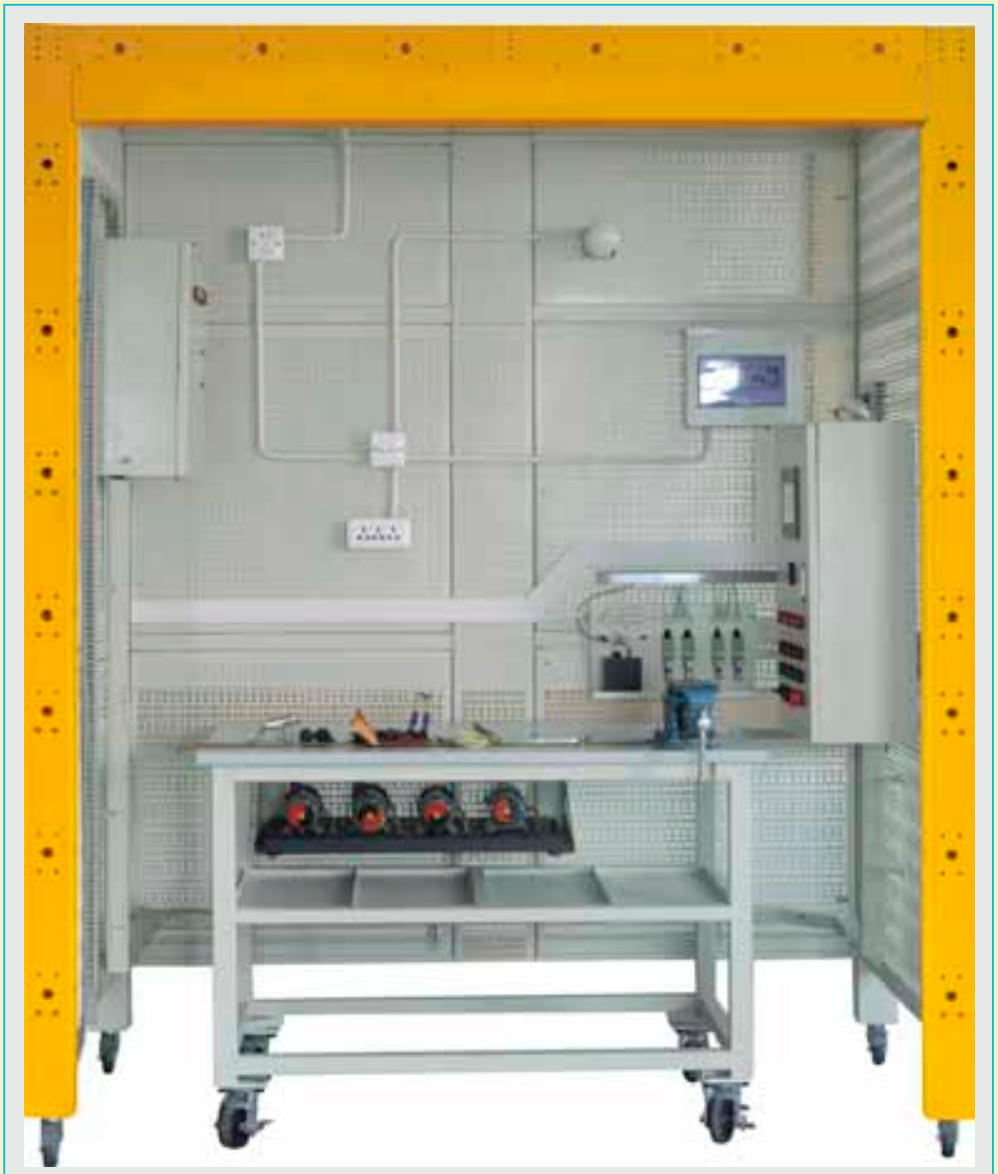

Basic electrical laboratory. Photo shows another angle of a domestic electrical workstation 


\subsection{ELECTRONICS LABORATORY}

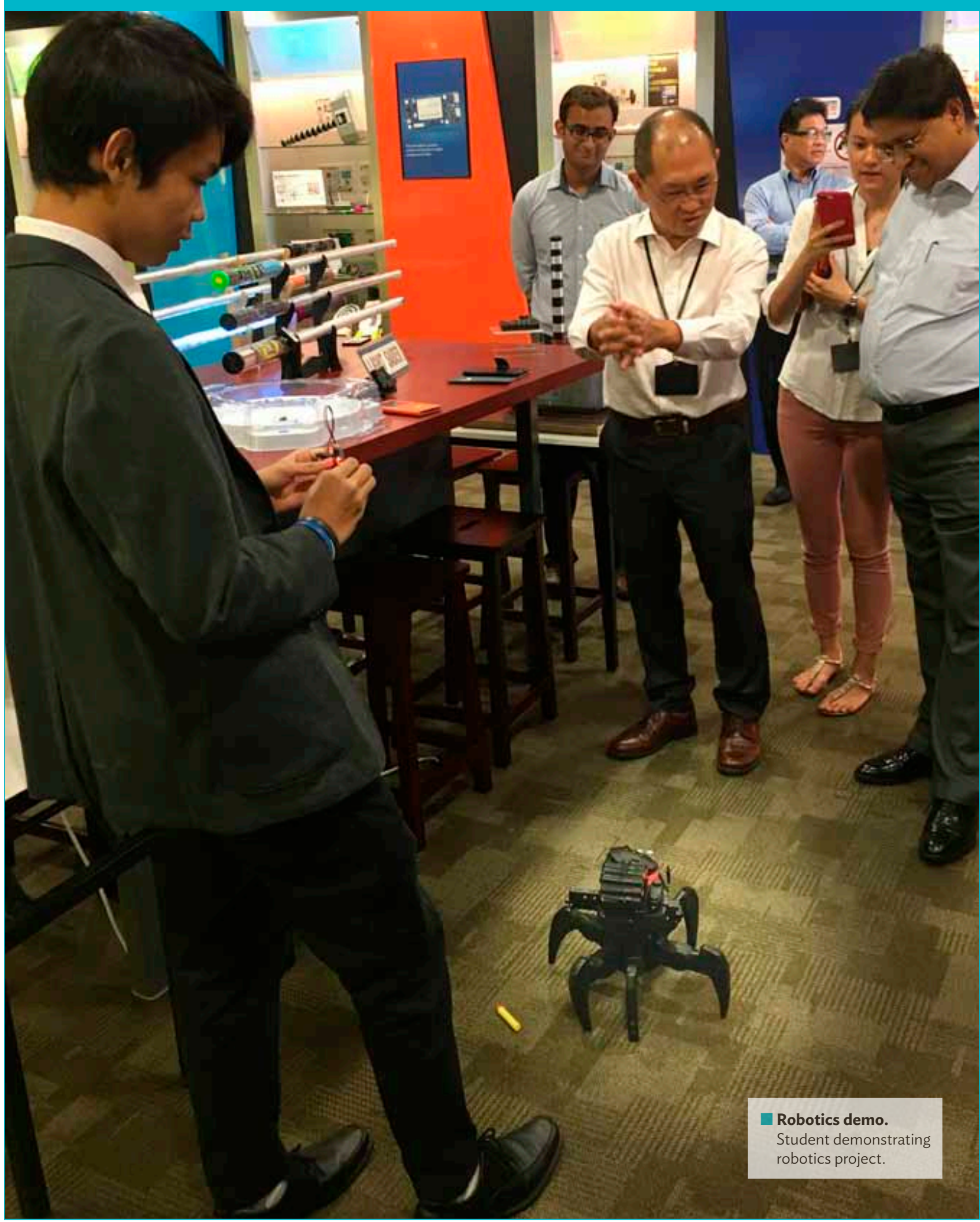




\subsubsection{Training Facility Norms}

\section{A. WORKSHOP FLOOR PLAN LAYOUT AND SIZE}

Figure 2: Layout of Electronics Laboratory

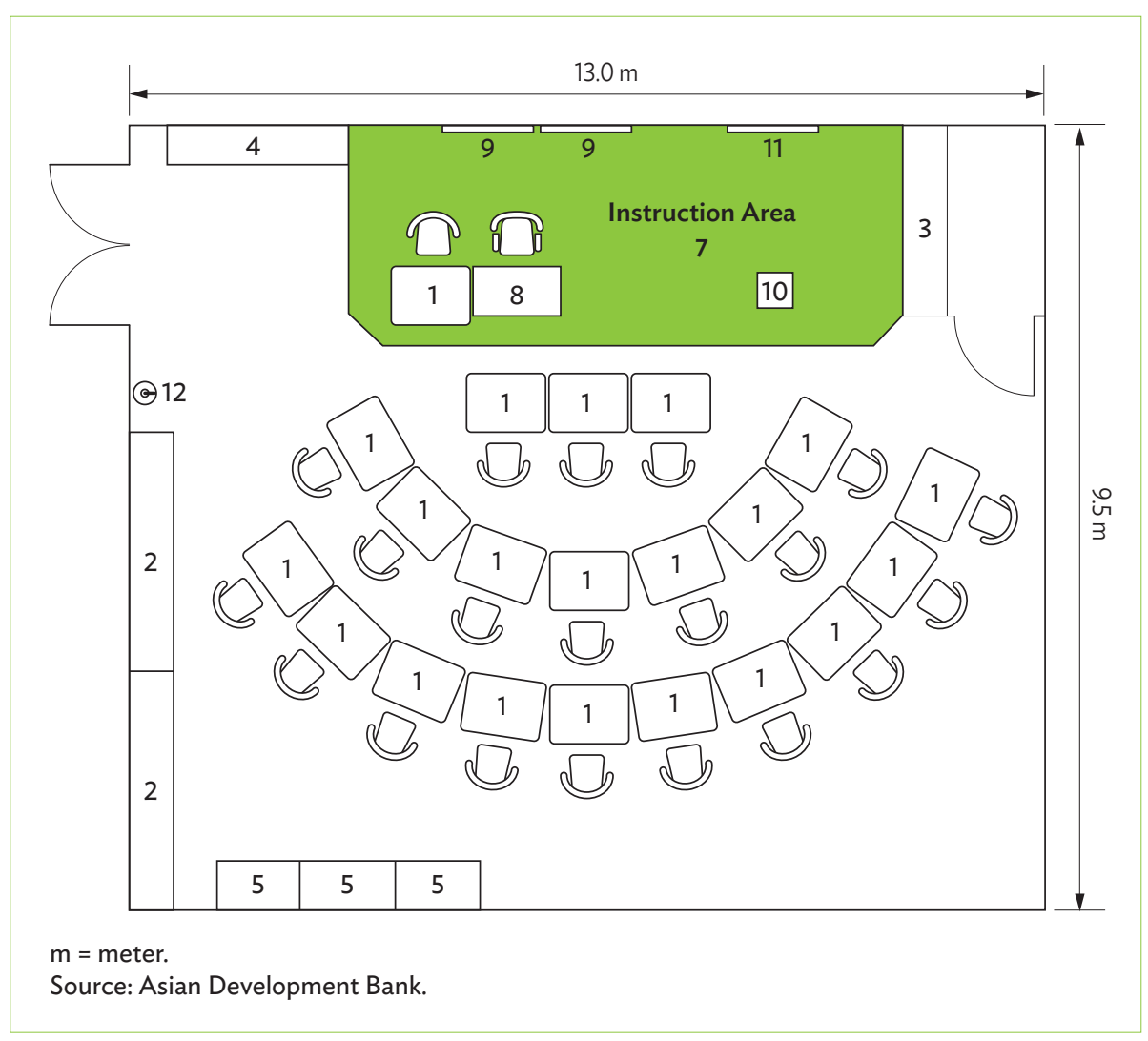

Table 4: Floor Area Requirement for Electronics Laboratory

\begin{tabular}{|c|c|c|c|c|}
\hline $\mathbf{S} / \mathbf{N}$ & Item & Quantity & Dimensions & Area \\
\hline 1 & Student learning area & 1 & $7.5 \mathrm{~m} \times 13 \mathrm{~m}$ & $97.5 \mathrm{~m}^{2}$ \\
\hline 2 & Electronic workbench & 20 & - & - \\
\hline 3 & Low cabinet & 2 & - & - \\
\hline 4 & Network printer & 2 & - & - \\
\hline 5 & Storage cabinet & 2 & - & - \\
\hline 6 & Steel cabinet & 2 & - & - \\
\hline 7 & Instruction area & 1 & $2 m \times 9 m$ & $18.0 \mathrm{~m}^{2}$ \\
\hline 8 & Teacher's table and chair set & 1 & - & - \\
\hline 9 & Whiteboard & 1 & - & - \\
\hline 10 & Ceiling overhead projector & 1 & - & - \\
\hline 11 & Projector (liquid crystal display) & 1 & - & - \\
\hline 12 & Fire extinguisher & 1 & - & - \\
\hline
\end{tabular}

- = not applicable, $m=$ meter, $m^{2}=$ square meter.

Source: Asian Development Bank. 


\subsubsection{Standard Equipment List}

Table 5: Laboratory and/or Workshop for Electronics Laboratory

\section{Name of the Laboratory and/or Workshop ELECTRONICS LABORATORY \\ Proposed Student Enrollment Size $\quad 20$ \\ Applicable Field of Usage \\ MECHANICAL TECHNOLOGY AND MECHATRONICS TECHNOLOGY}

\begin{tabular}{|c|c|c|}
\hline Parameter & Norm & Remarks \\
\hline $\begin{array}{l}\text { Size of Laboratory } \\
\text { and/or Workshop }\end{array}$ & $9.5 \mathrm{~m} \times 13 \mathrm{~m} \times 4 \mathrm{~m}$ (length $\times$ width $\times$ height $)$ & \\
\hline $\begin{array}{l}\text { Electrical Loading } \\
\text { Requirement }\end{array}$ & $\begin{array}{l}\text { Two 16A twin-socket electrical outlet should be provided for each } \\
\text { electronic workstation } \\
1216 \mathrm{~A} \text { electrical socket outlet should be provided for general use in the } \\
\text { laboratory } \\
\text { All electrical installation should comply with local regulations } \\
\text { Two emergency stop-buttons should be provided }\end{array}$ & \\
\hline Floor Loading Requirement & $350 \mathrm{~kg} / \mathrm{m}^{2}$ & \\
\hline $\begin{array}{l}\text { Lighting Requirement } \\
\text { (Lumen) }\end{array}$ & $\begin{array}{l}\text { Standard ceiling flourescent lightings at } 25 \mathrm{~W} / \mathrm{m}^{2} \\
\text { Emergency lights }\end{array}$ & \\
\hline Flooring Requirement & $\begin{array}{l}\text { Raised flooring to facilitate wire cabling from below floor } \\
\text { Vinyl composition to reduce dust and improve electrical insulation }\end{array}$ & \\
\hline $\begin{array}{l}\text { Location of Laboratory } \\
\text { and/or Workshop } \\
\text { (Floor) }\end{array}$ & Any floor & \\
\hline $\begin{array}{l}\text { Laboratory and/or } \\
\text { Workshop Climatic } \\
\text { Condition }\end{array}$ & Air-conditioned & \\
\hline $\begin{array}{l}\text { Building Safety Code } \\
\text { Requirement }\end{array}$ & Comply with national safety code requirements & \\
\hline Door Width & At least $1.5 \mathrm{~m}$ wide & \\
\hline First Aid Requirement & Adhering to building safety code & \\
\hline Storage Area Requirement & One storage cabinet & \\
\hline $\begin{array}{l}\text { Built-in Furniture } \\
\text { Requirement }\end{array}$ & Not applicable & \\
\hline
\end{tabular}

$\mathrm{A}=$ ampere $\mathrm{kg}=$ kilogram, $\mathrm{m}=$ meter, $\mathrm{m}^{2}=$ square meter, $\mathrm{W}=$ watt.

Source: Asian Development Bank. 


\section{B. TECHNICAL SPECIFICATIONS FOR THE WORKSHOP}

Table 6: Electronics Laboratory Equipment Specification

\section{Name of the Laboratory and/or Workshop ELECTRONICS LABORATORY \\ Proposed Student Enrollment Size \\ 20 \\ Applicable Field of Usage \\ ELECTRONICS, ELECTRICAL, MECHATRONICS, AND AUTOMOTIVE}

\section{S/N Name of Item \\ Description of Item \\ Quantity \\ Remarks}

A Training Equipment and/or Machine: $\$ 300,000.00$

Basic Electronics PC board dimensions: 11-5/8" × 5-1/4"

20 units

Trainer

Operates on 9-volt battery

Includes complete course study guide

Electronics kit to contain:

Audio amplifier, AM detector

AM IF

AM amplifier

AM mixer and oscillator

FM detector

1st FM IF

2nd FM

FM RF stages

Instrumentation amplifier

20 units

Shield boards

20 units

Active low pass filters

20 units

Small DC motor drivers

20 units

Various break-out boards

20 units

Electronic simulation software

School license To be installed

in hydraulic or

pneumatic PC room

Trainers' Training should be provided

B Tools and Accessories

\begin{tabular}{|c|c|c|c|}
\hline & & Oscilloscope & 20 units \\
\hline & & Multi-meter & 20 units \\
\hline & & $\begin{array}{l}\text { Power supply: } 230 \text { VAC input, 0-24 VDC output variable voltage } \\
\text { with short circuit protection }\end{array}$ & 20 units \\
\hline & & Soldering and de-soldering station complete with accessories & 20 units \\
\hline & & Signal generator & 20 units \\
\hline & & Test cables & 20 units \\
\hline & & Hot air gun to be used for shrinkable tubing & 20 units \\
\hline & & Blank printed circuit board & 20 units \\
\hline & & Wire stripper & 20 units \\
\hline & & Basic electronic parts & 20 sets \\
\hline & & 9-Volt battery & 20 units \\
\hline & & Cross screwdriver precision & 20 units \\
\hline & & Straight screwdriver precision & 20 units \\
\hline & & Bread board & 100 units \\
\hline C & Furniture & & \\
\hline & & $\begin{array}{l}\text { Workbench complete with storage cabinet: } \\
1,300 \times 750 \times 1,800 \mathrm{~mm}(\text { length } \times \text { width } \times \text { height })\end{array}$ & 20 sets \\
\hline & & Mobile whiteboard, $1,500 \times 1,000 \mathrm{~mm}$ double-sided with castors & 1 set \\
\hline & & Projector (liquid crystal display) & 1 set \\
\hline & & Teacher's table and chair set & 1 set \\
\hline & & Students' chairs & 20 sets \\
\hline
\end{tabular}

$\mathrm{AM}=$ amplitude modulation, $\mathrm{DC}=$ direct current, $\mathrm{FM}=$ frequency modulation, $\mathrm{IF}=$ intermediate frequency, $\mathrm{mm}=$ millimeter,

$\mathrm{PC}=$ personal computer, $\mathrm{RF}=$ radio frequency, $\mathrm{VAC}=$ voltage in alternating current, $\mathrm{VDC}=$ voltage direct current. 


\subsubsection{Sample Photo for Electronics Laboratory}

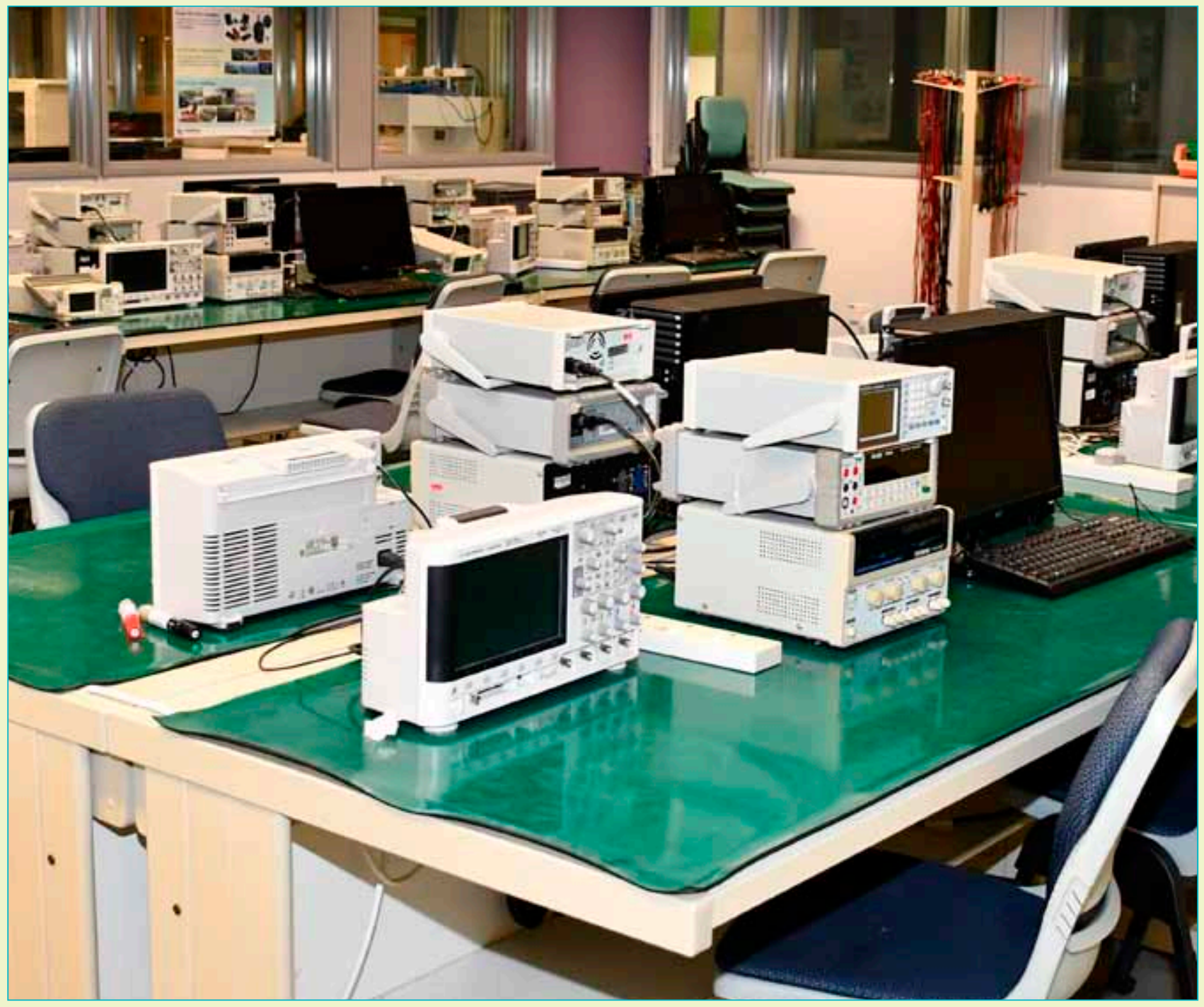

Eletronics training equipment. Signal generator, power supply, and oscilloscope. 


\section{HYDRAULICS \\ AND PNEUMATIC \\ TRAINING FACILITIES}

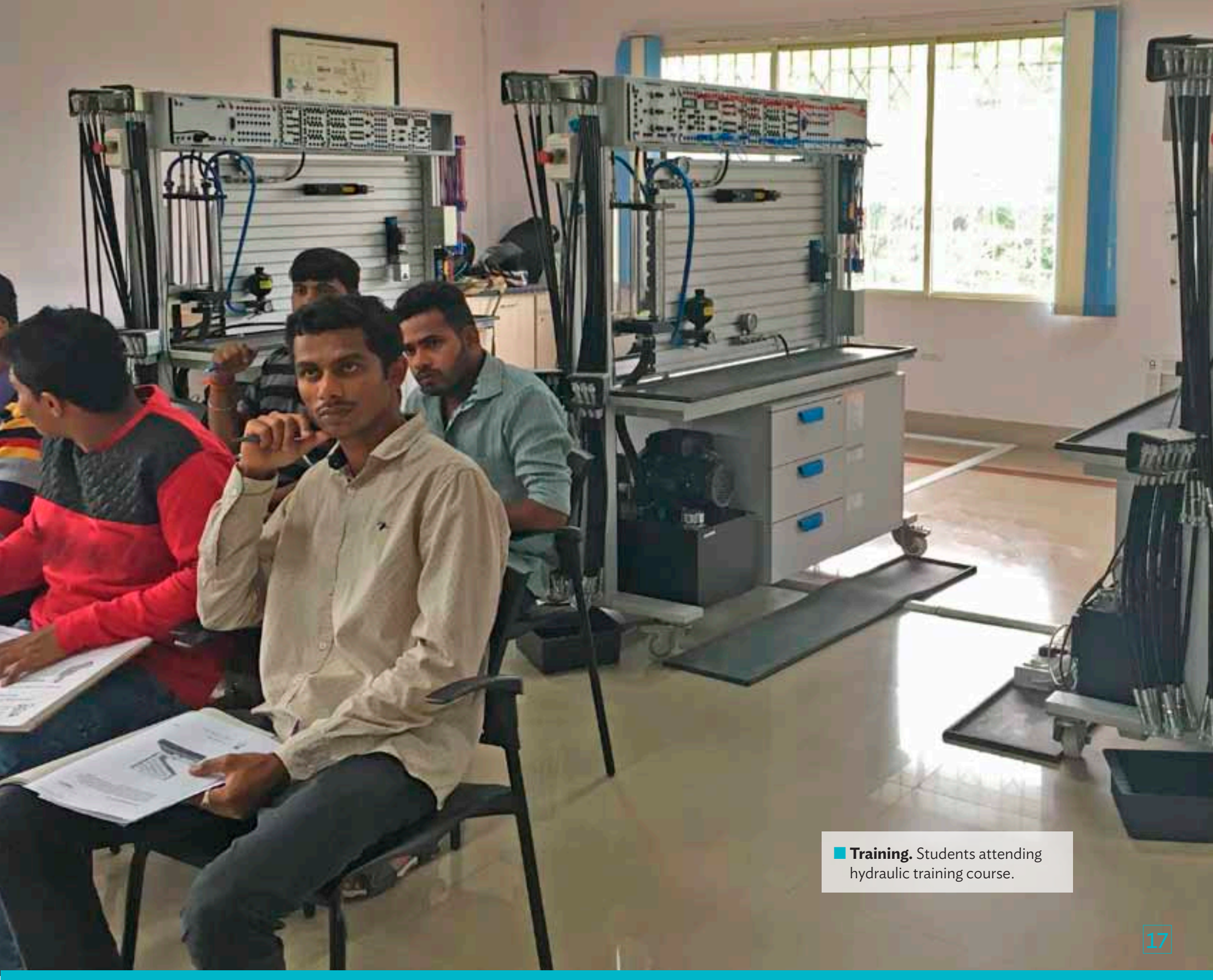




\subsection{HYDRAULICS LABORATORY}

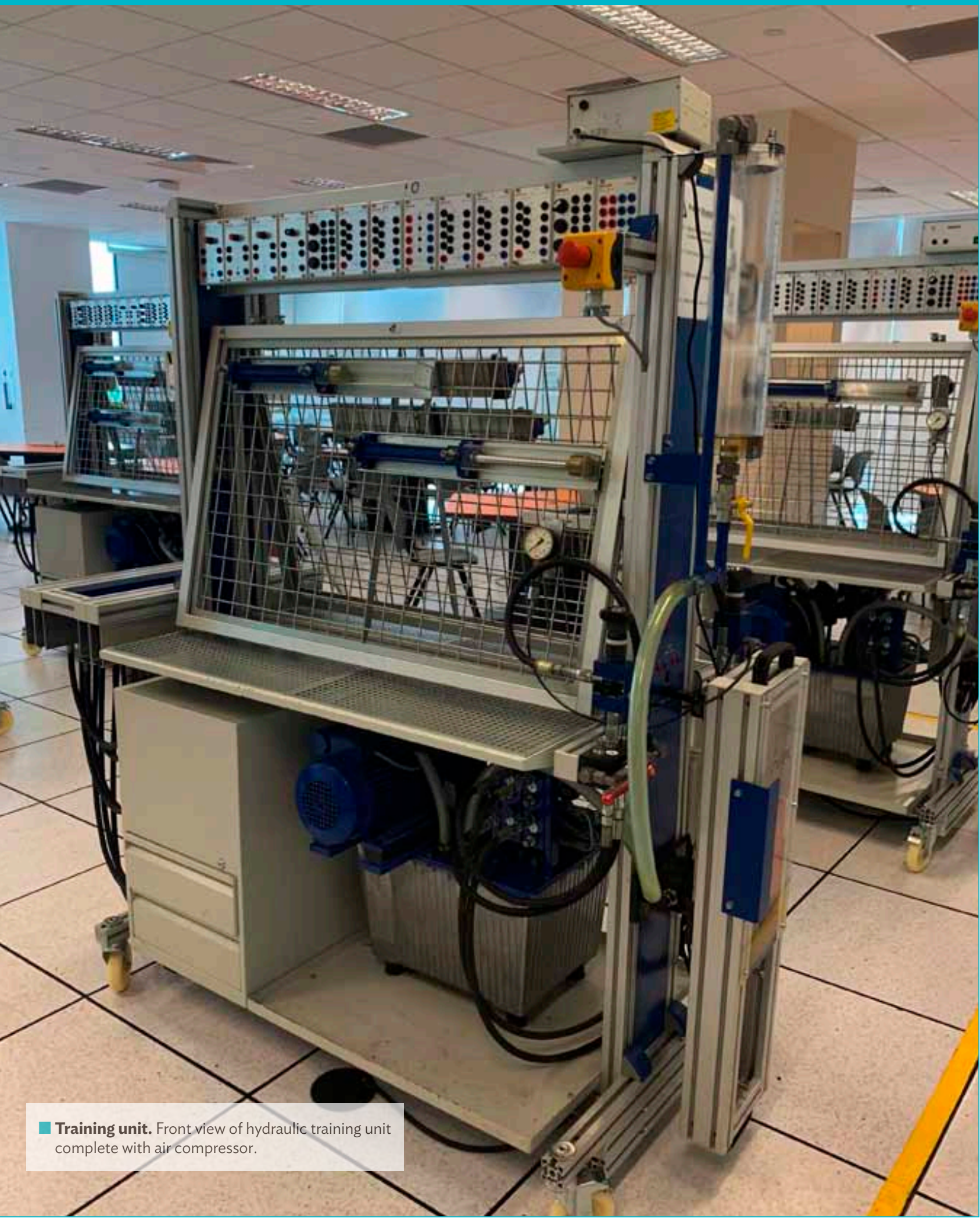




\subsubsection{Training Facility Norms}

\section{A. WORKSHOP FLOOR PLAN LAYOUT AND SIZE}

Figure 3: Layout of Hydraulic Laboratory

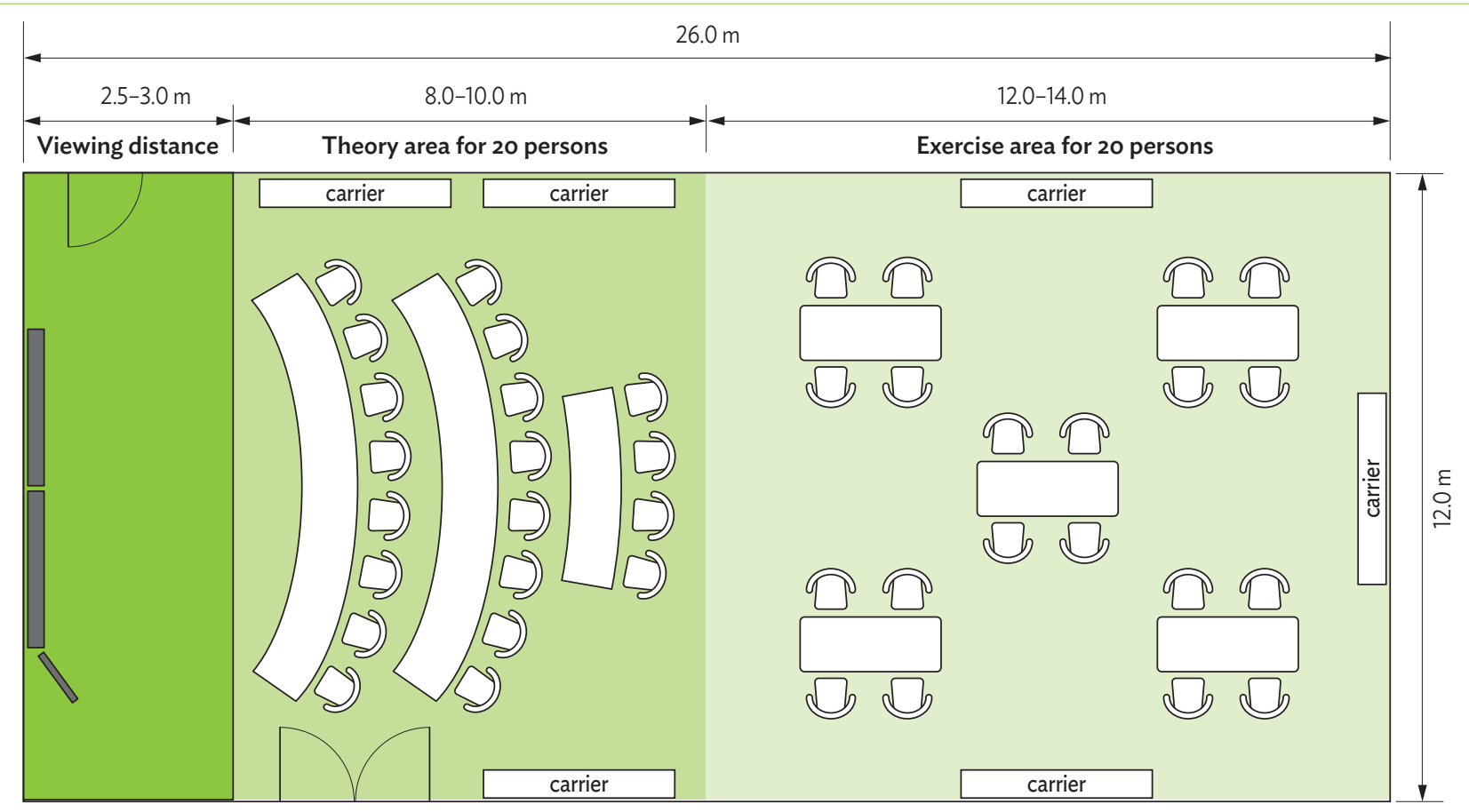

$\mathrm{m}=$ meter.

Source: Asian Development Bank.

Table 7: Floor Area Requirement for Hydraulic Laboratory

\begin{tabular}{|c|c|c|c|c|}
\hline $\mathbf{S} / \mathbf{N}$ & Item & Quantity & Dimensions & Area \\
\hline 1 & Hydraulic training area & 1 & $14 m \times 12 m$ & $168 m^{2}$ \\
\hline 2 & Hydraulic trainer & 5 & - & - \\
\hline 3 & Carrier & 5 & - & - \\
\hline 4 & $\begin{array}{l}\text { Students' theory and computer area for hydraulic } \\
\text { design and simulation training }\end{array}$ & 1 & $10 \mathrm{~m} \times 12 \mathrm{~m}$ & $120 \mathrm{~m}^{2}$ \\
\hline 5 & Instruction area & 1 & $2.5 \mathrm{~m} \times 10 \mathrm{~m}$ & $25 \mathrm{~m}^{2}$ \\
\hline 6 & Whiteboard & 1 & - & - \\
\hline 7 & Ceiling projector & 1 & - & - \\
\hline 8 & Screen & 1 & - & - \\
\hline 9 & Fire extinguisher & 1 & - & - \\
\hline 10 & Teacher's table and chair set & 1 & - & - \\
\hline
\end{tabular}

$-=$ not applicable, $m=$ meter, $\mathrm{m}^{2}=$ square meter.

Source: Asian Development Bank. 


\section{B. TECHNICAL SPECIFICATIONS FOR THE WORKSHOP}

Table 8: Laboratory and/or Workshop for Hydraulic Laboratory

$\begin{array}{ll}\text { Name of the Laboratory and/or Workshop } & \text { HYDRAULIC LABORATORY } \\ \text { Proposed Student Enrollment Size } & 20\end{array}$

\section{Parameter}

Size of Laboratory and/or Workshop

Electrical Loading Requirement

\section{Norm}

Remarks
$26 \mathrm{~m} \times 12 \mathrm{~m} \times \mathbf{4} \mathbf{m}$ (length $\times$ width $\times$ height $)$

One 16A twin-socket electrical outlet should be provided for each hydraulic trainer

One 16A twin-socket electrical outlet should be provided in each computer table

$1216 \mathrm{~A}$ electrical socket outlet should be provided for general use in the laboratory

All electrical installation should comply with local regulations

Two emergency stop-buttons should be provided

Floor Loading Requirement

Lighting Requirement (Lumen)

Flooring Requirement

Location of Laboratory and/or Workshop (Floor)

Laboratory and/or Workshop Climatic Condition

Building Safety Code Requirement Door Width

First Aid Requirement

Storage Area Requirement

Built-in Furniture Requirement
$350 \mathrm{~kg} / \mathrm{m}^{2}$

Standard ceiling flourescent lightings at $25 \mathrm{~W} / \mathrm{m}^{2}$

Emergency lights

Raised flooring to facilitate wire cabling from below floor

Vinyl composition to reduce dust and improve electrical insulation

Any floor

Air-conditioned

Comply with national safety code requirements

At least $1.5 \mathrm{~m}$ wide

Adhering to building safety code

5 carriers for storage of parts and components

Not applicable

$\mathrm{A}=$ ampere, $\mathrm{kg}=$ kilogram, $\mathrm{m}=$ meter, $\mathrm{m}^{2}=$ square meter, $\mathrm{W}=$ watt.

Source: Asian Development Bank. 


\subsubsection{Standard Equipment List}

Table 9: Hydraulic Laboratory Specification

\section{Name of the Laboratory and/or Workshop HYDRAULICS LABORATORY \\ Proposed Student Enrollment Size \\ 20 \\ Applicable Field of Usage \\ MECHANICAL, ELECTRICAL, MECHATRONICS, AND AUTOMOTIVE}

S/N Name of Item

Description of Item

Quantity Remarks

A Training Equipment / Machine: $\$ 1,000,000.00$

1 Basic Hydraulics with Troubleshooting Trainer

Pressure relief valve

2-way flow control valve

1-way flow control valve

Non-return valve, lockable

Non-return valve, 6 bars opening pressure

4/2-way hand lever valve, spring return

4/3-way hand lever valve, relieving mid-position, detented

4/3-way hand lever valve, closed mid-position, detented

Shut-off valve

Differential cylinder minimum 16/10/200 with cover

Weight, minimum 8 kg for cylinder

Hydraulic motor

T-distributor

4-way distributor with pressure gauge

Pressure gauge

Flow sensor

Workbook: Hydraulics Basic Level

Shut-off valve, defective

1-way flow control valve, defective

Pressure relief valve, defective

2 -way flow control valve, defective

$1 \times 4 / 3$-way hand lever valve, center position, detented

Flow control valve

Differential cylinder minimum 16/10/200, defective

Hose line with quick release couplings, clogged

Design and simulation software

Textbook: Basic Principles of Hydraulics and Electro-Hydraulics

\section{$2 \quad$ Advanced Hydraulics Trainer}

Pressure relief valve, compensated

3-way pressure reducing valve

Flow dividing valve

2/2-way stem actuated valve, convertible

Non-return valve, 6 bars opening pressure

Diaphragm accumulator with shut-off block

Differential cylinder minimum 16/10/200 with cover

Mounting kit for cylinders

T-distributor

Workbook: Hydraulics Advanced Level

Design and simulation software for advanced hydraulics
10 units

10 units

10 units

10 units

10 units

10 units

10 units

10 units

10 units

10 units

10 units

10 units

10 units

20 units

30 units

10 units

20 units

10 units

10 units

10 units

10 units

10 units

10 units

10 units

10 units

School license

20 units

10 units

10 units

10 units

10 units

30 units

10 units

10 units

10 units

10 units

20 sets

School license To be installed

in $\mathrm{PC}$ room

hydraulic 
Table 9 continued

S/N Name of Item

Description of Item

Quantity

Remarks

3 Basic Electro-Hydraulics Trainer with Supplementary Equipment Set and PLC (Electro-Hydraulics)

Pressure relief valve

2-way flow control valve

1 -way flow control valve

Non-return valve, 6 bars opening pressure

4/2-way solenoid valve, spring return

4/3-way solenoid valve, closed mid-position

4/2-way double solenoid valve, detented

Shut-off valve

Weight, minimum $8 \mathrm{~kg}$, for cylinder

Differential cylinder minimum 16/10/200 with cover

Mounting kit for cylinders

T-distributor

4-way distributor with pressure gauge

Pressure gauge

Pressure switch, electronic

Relay, three-fold

Signal input, electrical

Limit switch, electrical, left-actuated

Limit switch, electrical, right-actuated

Proximity sensor, electronic

Workbook: Electro-Hydraulics Basic Level

Design and Simulation Software for Electro-Hydraulics

(Ladder Logic)

Instruction manual for use of the software simulator (in English)

USB port

Quick-fix screw adapter

Universal connection unit, digital

I/O data cable connectors (IEEE 488), minimum 2 m

Instruction manual for use of the PLC programming software

Compact programmable logic controller

Programming software for the above programmable logic controller

Ethernet cable
10 units

10 units

10 units

10 units

20 units

20 units

20 units

10 units

10 units

30 units

20 units

30 units

20 units

20 units

20 units

30 units

20 units

20 units

20 units

30 units

20 sets

School license

10 units

10 units

10 units

10 units

10 units

10 units

10 units

10 units

10 units

\section{Advanced Level Electro-Hydraulics Trainer}

Time relay, two-fold

Relay, three-fold

Preset counter, electronic

Diaphragm accumulator with shut-off block

Hydraulic motor

4/3-way solenoid valve, relieving mid-position

Proximity sensor, inductive, $M 12$

Emergency stop push-button, electrical

T-distributor

Non-return valve, lockable

Pressure relief valve, compensated

Workbook: Electro-Hydraulics Advanced Level

Design and simulation software for electro-hydraulics advanced level School license

Textbook: Basic Principles of Hydraulics and Electro-hydraulics

Trainers' Training should be provided

5 Latest Version of Personal Computer

i7 Processor or higher

10 units

20 units

10 units

10 units

10 units

10 units

10 units

10 units

10 units

10 units

10 units

20 units

16 GB RAM

20 sets

1 TB HDD

Video card latest specification

Latest version OS

MS Office Suite

Network printer 


\section{S/N Name of Item}

\section{B Tools and Accessories}

\section{Description of Item}

Quantity

\section{Remarks}

(Included in

Hydraulic Trainer Price)

Mobile workstation with extruded aluminum profile plate

(length $\times$ width $\times$ height): $1,800 \times 800 \times 1,080 \mathrm{~mm}$

Hydraulic power unit AC $230 \mathrm{~V} 50 / 60 \mathrm{~Hz}$ - power pack with

AC motors, single-phase and start capacitors -

flow rate: $2 \times 3.4$ liter $/ \mathrm{min}$

Protective cover for weight

8 pieces hose line with quick release couplings: $600 \mathrm{~mm}$ minimum

$4 \mathrm{pcs}$. hose line with quick release couplings: $1,000 \mathrm{~mm}$ minimum

$2 \mathrm{pcs}$. hose line with quick release couplings: 1,500 $\mathrm{mm}$ minimum

Digital multi-meter

Power supply unit for mounting frame - input voltage: $230 \mathrm{VAC}$

$(50-60 \mathrm{~Hz})$ - Output voltage: $24 \mathrm{~V} \mathrm{DC}$, short-circuit-proof -

output current: 3 A minimum

Power cable connector as per BS 1363 for Great Britain;

Hong Kong, China; Ireland; Malaysia; Singapore; Ukraine; and

United Arab Emirates or equivalent to country standard

$4 \mathrm{~mm}$ safety laboratory cables, 120 pieces, red, blue, and black

17 pieces, red $50 \mathrm{~mm}$

17 pieces, blue $50 \mathrm{~mm}$

8 pieces, black $50 \mathrm{~mm}$

8 pieces, red $300 \mathrm{~mm}$

8 pieces, blue $300 \mathrm{~mm}$

18 pieces, black $300 \mathrm{~mm}$

8 pieces, red $500 \mathrm{~mm}$

8 pieces, blue $500 \mathrm{~mm}$

18 pieces, black $500 \mathrm{~mm}$

2 pieces, red 1,000 $\mathrm{mm}$

3 pieces, blue $1,000 \mathrm{~mm}$

2 pieces, black $1,000 \mathrm{~mm}$

1 piece, red $1,500 \mathrm{~mm}$

1 piece, blue $1,500 \mathrm{~mm}$

1 piece, black 1,500 mm
10 units

10 units

10 units

10 units

10 units

10 units

10 units

10 units

10 units

10 units

\begin{tabular}{l|l} 
Teacher's table and chair set & $\begin{array}{c}1 \text { unit } \\
\text { Computer table and chair set for students }\end{array}$ \\
\hline Projector (liquid crystal display) & $\begin{array}{c}\text { To be installed } \\
\text { in PC room } \\
\text { hydraulic }\end{array}$ \\
\hline Whiteboard & 1 unit \\
\hline Projector screen & 1 unit \\
\hline
\end{tabular}

$\mathrm{AC}=$ alternating current, $\mathrm{BS}=$ British Standard, $\mathrm{GB}=$ gigabyte, $\mathrm{HDD}=$ hard disk drive, $\mathrm{Hz}=$ hertz, IEEE = Institute of Electrical and Electronics Engineers, $\mathrm{I} / \mathrm{O}=$ input/output, $\mathrm{kg}=$ kilogram, $\mathrm{M}=$ metric, $\mathrm{min}=$ minute, $\mathrm{mm}=$ millimeter, $\mathrm{MS}=$ Microsoft, $\mathrm{OS}=$ operating system, $\mathrm{PC}=$ personal computer, $\mathrm{PLC}=$ programmable logic controller, $\mathrm{TB}=$ terabyte, $\mathrm{V}=$ volt, $\mathrm{VAC}=$ voltage in alternating current, $\mathrm{VDC}=$ voltage direct current.

Source: Asian Development Bank. 


\subsubsection{Sample Photo for Hydraulic Laboratory}

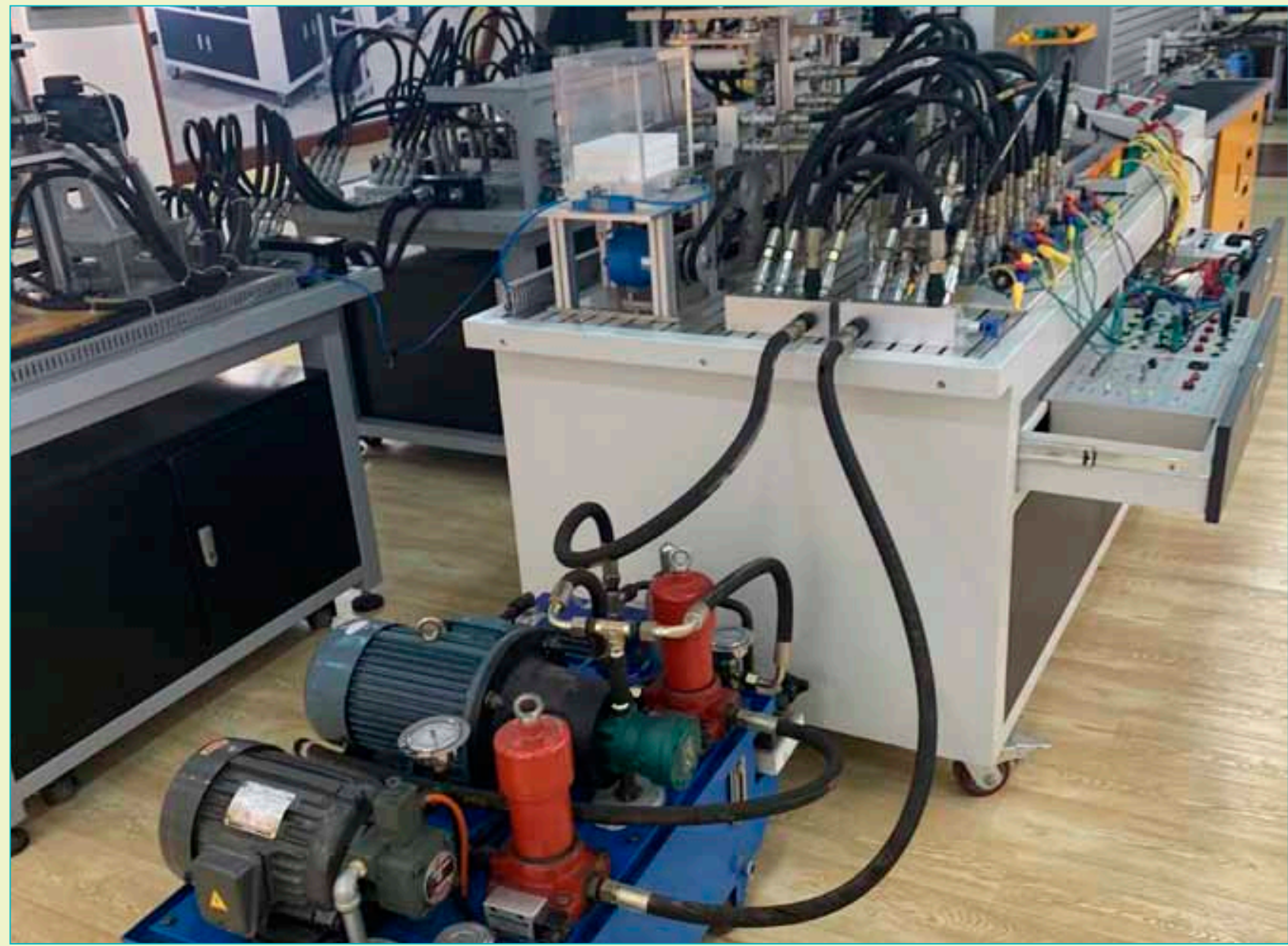

Air compressor. Lateral view of hydraulic training unit. 


\subsection{PNEUMATIC LABORATORY}

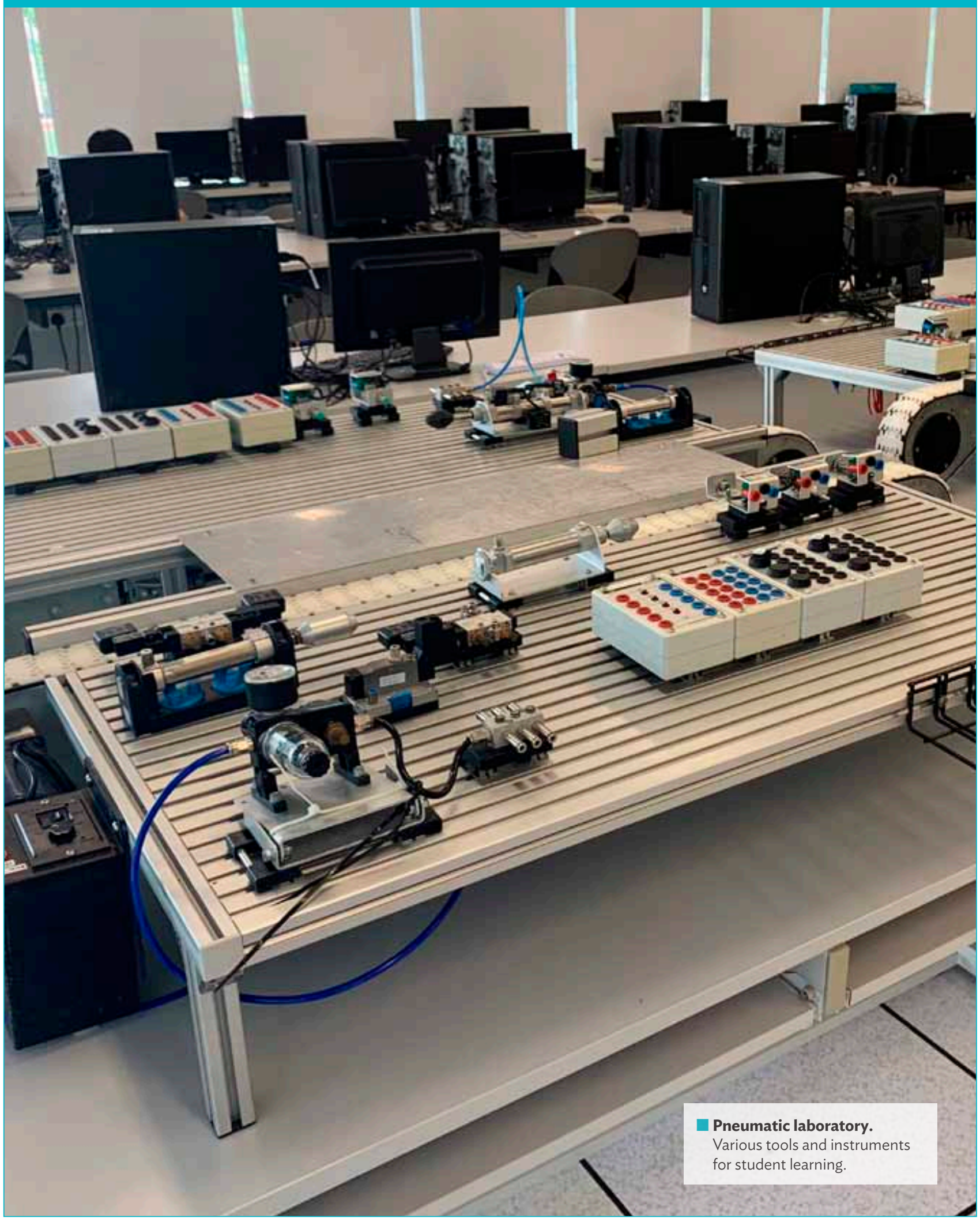




\subsubsection{Training Facility Norms}

\section{A. WORKSHOP FLOOR PLAN LAYOUT AND SIZE}

Figure 4: Layout of Pneumatic Laboratory

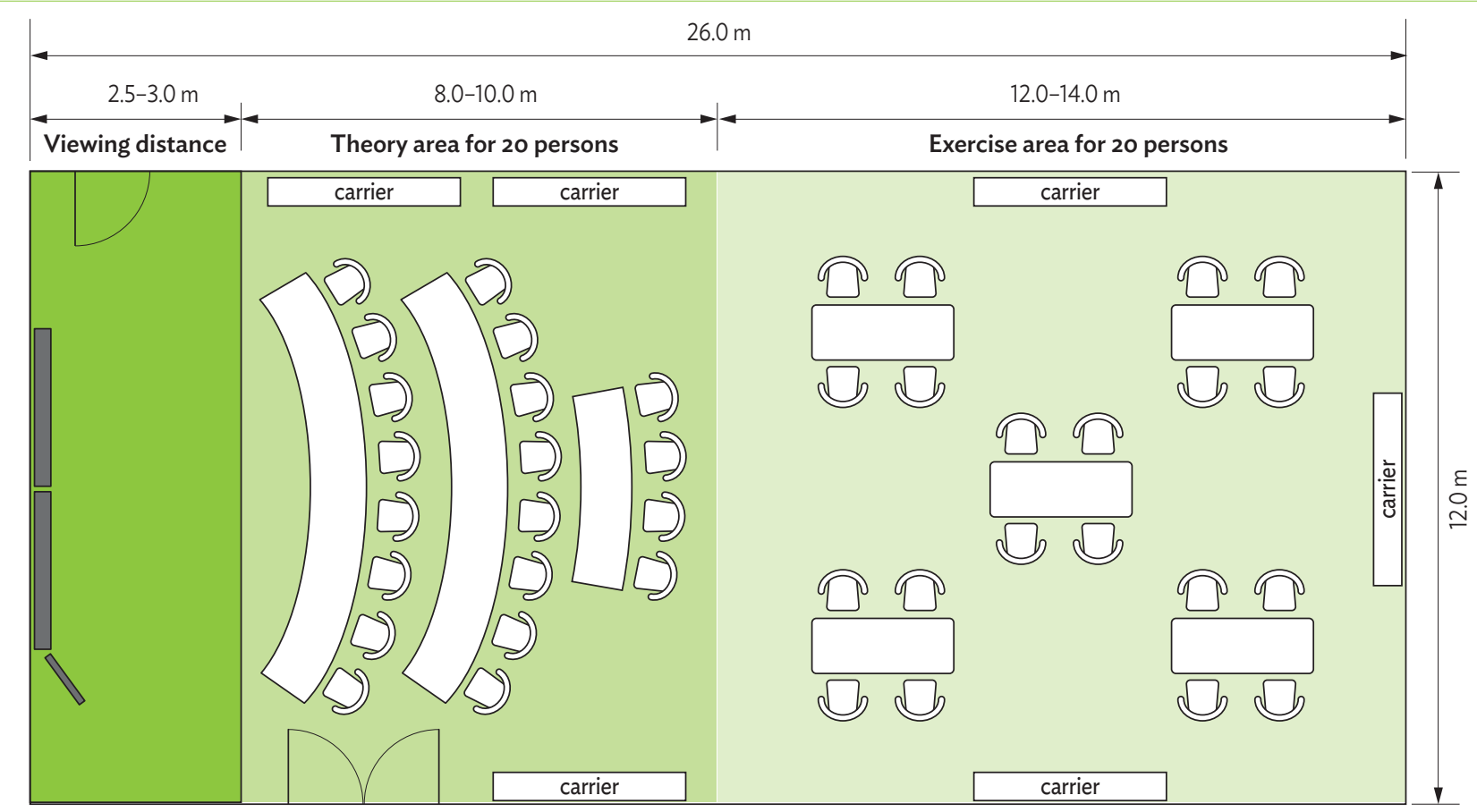

$\mathrm{m}=$ meter.

Source: Asian Development Bank.

Table 10: Floor Area Requirement for Pneumatic Laboratory

\begin{tabular}{|c|c|c|c|c|}
\hline $\mathbf{S} / \mathbf{N}$ & Item & Quantity & Dimensions & Area \\
\hline 1 & Pneumatic training area & 1 & $14 \mathrm{~m} \times 12 \mathrm{~m}$ & $168 \mathrm{~m}^{2}$ \\
\hline 2 & Pneumatic trainer & 5 & - & - \\
\hline 3 & Carrier & 5 & - & - \\
\hline 4 & $\begin{array}{l}\text { Students' theory and computer area for pneumatic } \\
\text { design and simulation training }\end{array}$ & 1 & $10 \mathrm{~m} \times 12 \mathrm{~m}$ & $120 \mathrm{~m}^{2}$ \\
\hline 5 & Instruction area & 1 & $2.5 \mathrm{~m} \times 10 \mathrm{~m}$ & $25 \mathrm{~m}^{2}$ \\
\hline 6 & Whiteboard & 1 & - & - \\
\hline 7 & Ceiling projector & 1 & - & - \\
\hline 8 & Projector screen & 1 & - & - \\
\hline 9 & Fire extinguisher & 2 & - & - \\
\hline 10 & Teachers' table and chair set & 1 & - & - \\
\hline
\end{tabular}

$-=$ not applicable, $m=$ meter, $m^{2}=$ square meter.

Source: Asian Development Bank. 


\section{B. TECHNICAL SPECIFICATIONS FOR THE WORKSHOP}

Table 11: Laboratory and/or Workshop for Pneumatic Laboratory

\begin{tabular}{|c|c|}
\hline $\begin{array}{l}\text { Name of the Laboratory and/or } \\
\text { Workshop }\end{array}$ & PNEUMATIC LABORATORY \\
\hline Proposed Student Enrollment Size & 20 \\
\hline Applicable Field of Usage & MECHANICAL TECHNOLOGY AND MECHATRONICS TECHNOLOGY \\
\hline
\end{tabular}

\section{Parameter}

Size of Laboratory and/or Workshop

Electrical Loading Requirement

\section{Norm}

\section{Remarks}

$\mathbf{2 6} \mathbf{m} \times \mathbf{1 2} \mathbf{m} \times \mathbf{4} \mathbf{m}$ (length $\times$ width $\times$ height)

One 16A twin socket electrical outlet should be provided for each pneumatic trainer

12 16A electrical socket outlets should be provided for general use in the laboratory

All electrical installation should comply with local regulations

Two emergency stop-buttons should be provided

Floor Loading Requirement $350 \mathrm{~kg} / \mathrm{m}^{2}$

Lighting Requirement (Lumen)

Flooring Requirement

Standard ceiling flourescent lightings at $25 \mathrm{~W} / \mathrm{m}^{2}$

Emergency lights

Raised flooring to facilitate wire cabling from below floor Vinyl composition to reduce dust and improve electrical insulation

Location of Laboratory and/or Workshop

Any floor (Floor)

Laboratory and/or Workshop Climatic Condition

Building Safety Code Requirement

Door Width

Air-conditioned

Comply with national safety code requirements

At least $1.5 \mathrm{~m}$ wide

First Aid Requirement

Adhering to building safety code

Storage Area Requirement

Five carriers for storage of parts and components

Built-in Furniture Requirement Not applicable

$\mathrm{A}=$ ampere, $\mathrm{kg}=$ kilogram, $\mathrm{m}=$ meter, $\mathrm{m}^{2}=$ square meter, $\mathrm{W}=$ watt.

Source: Asian Development Bank. 


\title{
3.2.2 Standard Equipment List
}

Table 12: Pneumatic Laboratory Equipment Specification

\author{
Name of the Laboratory and/or Workshop PNEUMATIC LABORATORY \\ Proposed Student Enrolment Size \\ 20 \\ Applicable Field of Usage \\ MECHATRONICS, MECHANICAL, AUTOMOTIVE, AND ELECTRICAL
}

1 Basic Pneumatics with Fault - Tracing Trainer

3/2-way valve with push-button actuator, normally closed

20 units

3/2-way valve with push-button actuator, normally open

10 units

$5 / 2$-way valve with selector switch

3/2-way valve with selector switch, normally closed

3/2-way roller lever valve, normally closed

10 units

Proximity sensor, pneumatic, with cylinder attachment

10 units

20 units

Pneumatic timer, normally closed

20 units

Pneumatic timer, normally open

10 units

Pressure sequence valve

10 units

3/2-way valve, pneumatically actuated at one end

10 units

$5 / 2$-way valve, pneumatically actuated at one end

10 units

$5 / 2$-way double pilot valve, pneumatically actuated at both ends

10 units

Shuttle valve (OR)

Dual-pressure valve (AND)

Quick-exhaust valve

units

10 units

20 units

1-way flow control valve

Single-acting cylinder

Double-acting cylinder

Start-up valve with filter control valve

Pressure regulator valve with gauge

10 units

20 units

10 units

10 units

10 units

Pressure gauge

Manifold

Plastic tubing, $4 \mathrm{~mm}$ OD blue $20 \mathrm{~m}$

10 units

20 units

20 units

20 units

Double-acting cylinder, defective

Pressure gauge, defective

Filter sleeves for on-off valve with filter regulator, clogged

3/2-way valve with push-button actuator, normally closed,

10 units

10 units

10 units defective

5/2-way bi-stable valve, defective

10 units

5/3-way valve, mid-position pressurized

10 units

10 units

Flow control valve

Silencer M5, clogged

Workbook: Pneumatics Basic Level

Basic pneumatic design and simulation simulator

10 units

20 units

20 sets

Textbook: Basic Principles of Pneumatics and Electro-Pneumatics

School license

$2 \quad$ Advanced Pneumatics Trainer

3/2-way valve with push-button actuator, normally closed

20 sets

3/2-way valve with mushroom-head emergency switch,

normally open

3/2-way roller lever valve with idle return, normally closed

Back pressure valve

3/2-way valve, pneumatically actuated at one end

$5 / 2$-way double pilot valve, pneumatically actuated at both ends

Plastic tubing, $4 \mathrm{~mm}$ OD blue $20 \mathrm{~m}$

Shuttle valve (OR)

20 units

10 units

10 units

10 units

40 units

20 units

20 units

40 units 


\begin{tabular}{|c|c|c|c|c|}
\hline $\mathbf{S} / \mathbf{N}$ & Name of Item & Description of Item & Quantity & Remarks \\
\hline & & $\begin{array}{l}\text { Dual-pressure valve (AND) } \\
\text { Pneumatic timer, normally open } \\
\text { Pneumatic pre-set counter } \\
\text { Stepper unit } \\
\text { 1-way flow control valve } \\
\text { Non-return valve, lockable } \\
\text { Double-acting cylinder } \\
\text { Workbook: Pneumatics Advanced Level }\end{array}$ & $\begin{array}{l}30 \text { units } \\
10 \text { units } \\
10 \text { units } \\
10 \text { units } \\
20 \text { units } \\
20 \text { units } \\
20 \text { units } \\
20 \text { units }\end{array}$ & \\
\hline
\end{tabular}

\section{Basic Electro-Pneumatics with Integrated PLC Trainer}

Signal input, electrical

Relay, three-fold

Timer, DPDT

Electronic counter NPN

Electronic counter PNP

Limit switch, electrical, left-actuated

Limit switch, electrical, right-actuated

Indicator unit and distributor, electrical

Emergency push-button twist and turn

Proximity sensor, inductive, $M 12$

Proximity sensor, capacitive, M12

Proximity sensor, optical, M12

Proximity sensor, electronic, with cylinder mounting

$2 \times 3 / 2$-way solenoid valve with LED, normally closed

$5 / 2$-way solenoid valve with LED

5/2-way double solenoid valve with LED

Valve terminal with 4 valves +1 spare valve

Pressure sensor with display

1-way flow control valve

Non-return valve

Single-acting cylinder

Double-acting cylinder

On/Off valve with filter control valve

Manifold

Plastic tubing, $4 \mathrm{~mm}$ OD blue $20 \mathrm{~m}$

Universal connection unit

Workbook: Programmable Logic Controller Basic Level

Textbook: Programmable Logic Controller Basic Level

Instruction manual for use of the software simulator (in English)

USB connector

Quick-fix screw adapter

Universal connection unit, digital

I/O data cable with connectors (IEEE 488), $3 \mathrm{~m}$ minimum

Instruction manual for use of the PLC programming software

Compact programmable logic controller

Programming software for the above programmable logic controller

Ethernet cable

Trainers' Training should be provided
40 units

40 units

10 units

10 units

10 units

10 units

10 units

10 units

10 units

40 units

40 units

40 units

80 units

20 units

20 units

30 units

10 units

10 units

40 units

10 units

20 units

40 units

20 units

20 units

20 units

20 units

20 sets

20 sets

10 sets

10 units

10 units

10 units

10 units

20 sets

10 units

School license

10 units

$4 \quad$ Latest Version of Personal Computer

i-7 processor or higher

20 units

16 GB RAM

1 TB HDD

Video card, latest specification

Latest version OS

MS Office Suite 
Table 12 continued

\section{S/N Name of Item}

Description of Item

Quantity Remarks

B Tools and Accessories

\section{Price}

included in

Pneumatic

Trainers

Mobile workstation with aluminum profile plate

10 units

(length $\times$ width $\times$ height) $1,800 \times 800 \times 1,080 \mathrm{~mm}$

Low noise compressor, at least 45dB, 230 VAC $50 / 60 \mathrm{~Hz}$

Power supply unit for mounting frame - input voltage: $230 \mathrm{VAC}$

10 units

10 units

(50-60 Hz) - output voltage: $24 \mathrm{~V} \mathrm{DC}$, short-circuit-proof output current: max. $4 \mathrm{~A}$

Power cable connector as per BS 1363 for Great Britain;

Hong Kong, China; Ireland; Malaysia; Singapore; Ukraine; and

United Arab Emirates or equivalent country standard

10 units

$4 \mathrm{~mm}$ safety laboratory cables, 120 pieces, red, blue, and black

110 sets

17 pieces, red $50 \mathrm{~mm}$

17 pieces, blue $50 \mathrm{~mm}$

8 pieces, black $50 \mathrm{~mm}$

8 pieces, red $300 \mathrm{~mm}$

8 pieces, blue $300 \mathrm{~mm}$

18 pieces, black $300 \mathrm{~mm}$

8 pieces, red $500 \mathrm{~mm}$

8 pieces, blue $500 \mathrm{~mm}$

18 pieces, black $500 \mathrm{~mm}$

2 pieces, red $1,000 \mathrm{~mm}$

3 pieces, blue $1,000 \mathrm{~mm}$

2 pieces, black $1,000 \mathrm{~mm}$

1 pieces, red $1,500 \mathrm{~mm}$

1 pieces, blue $1,500 \mathrm{~mm}$

1 pieces, black 1,500 $\mathrm{mm}$

\section{Furniture}

Trainer's table and chair set

Students table and chair sets

Projector (liquid crystal display)

Screen

Whiteboard
1 unit

20 sets PC room for pneumatics simulation training 1 unit 1 unit

1 unit

$\mathrm{A}=$ ampere, $\mathrm{BS}=$ British Standard, $\mathrm{dB}=$ decibel, $\mathrm{DPDT}=$ double pole double throw, $\mathrm{GB}=$ gigabyte, $\mathrm{HDD}=$ hard disk drive, $\mathrm{Hz}=$ hertz, $\mathrm{IEEE}=$ Institute of Electrical and Electronics Engineers, $\mathrm{I} / \mathrm{O}=$ input/output, $\mathrm{LED}=$ light-emitting diode, $\mathrm{M}=$ metric, $\mathrm{mm}=$ millimeter, $M S=$ Microsoft, $N P N=$ negative-positive-negative,$O D=$ outside diameter, $O S=$ operating system, $P C=$ personal computer, $\mathrm{PLC}=$ programmable logic controller, $\mathrm{PNP}=$ positive-negative-positive, $\mathrm{Pt}=$ platinum, $\mathrm{TB}=$ terabyte, $\mathrm{VAC}=$ voltage in alternating current, $\mathrm{VDC}=$ voltage direct current.

Source: Asian Development Bank. 


\subsubsection{Sample Photos for Pneumatic Laboratory}
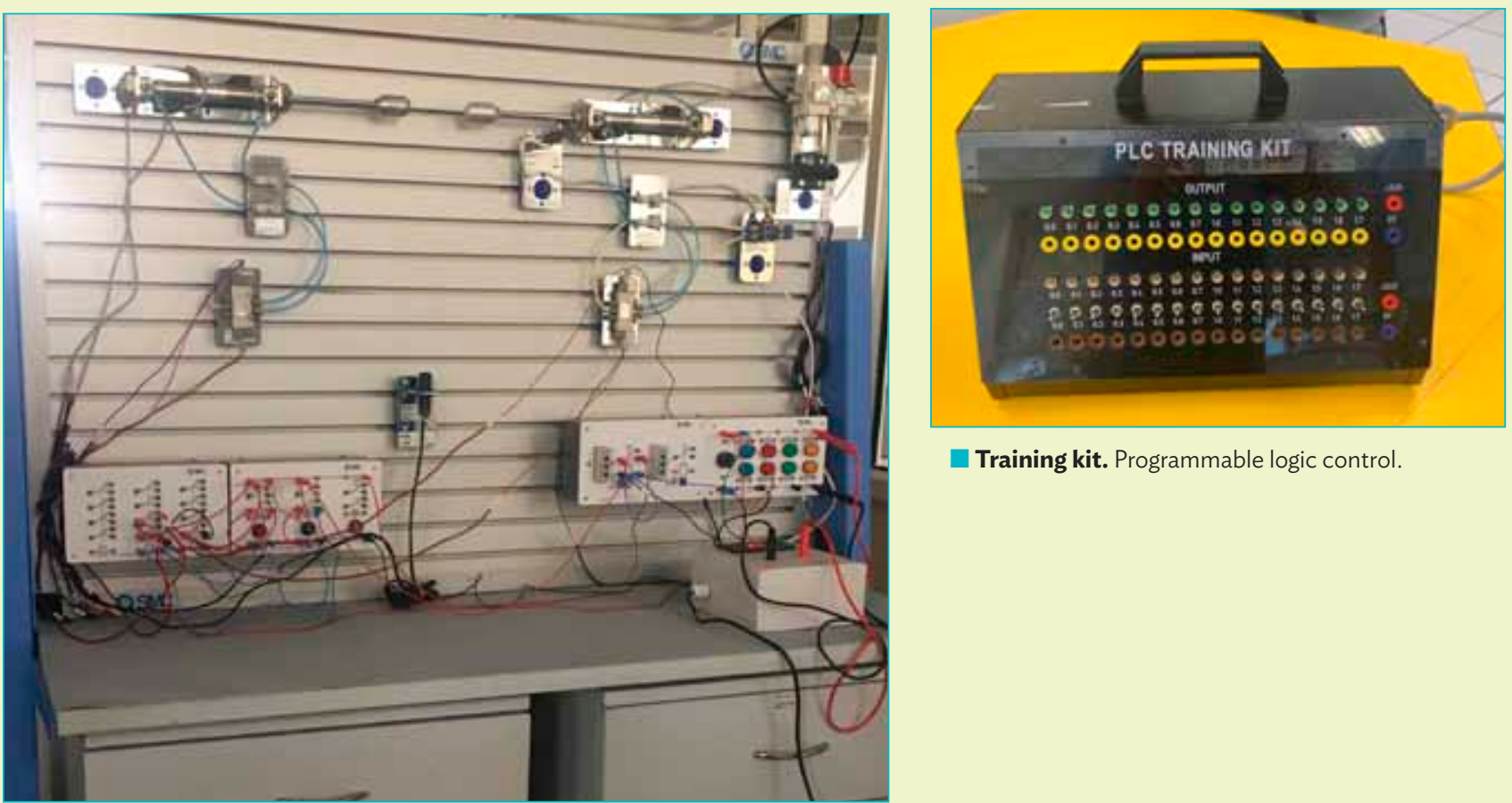

Training kit. Programmable logic control.

Work station. Pneumatic training.

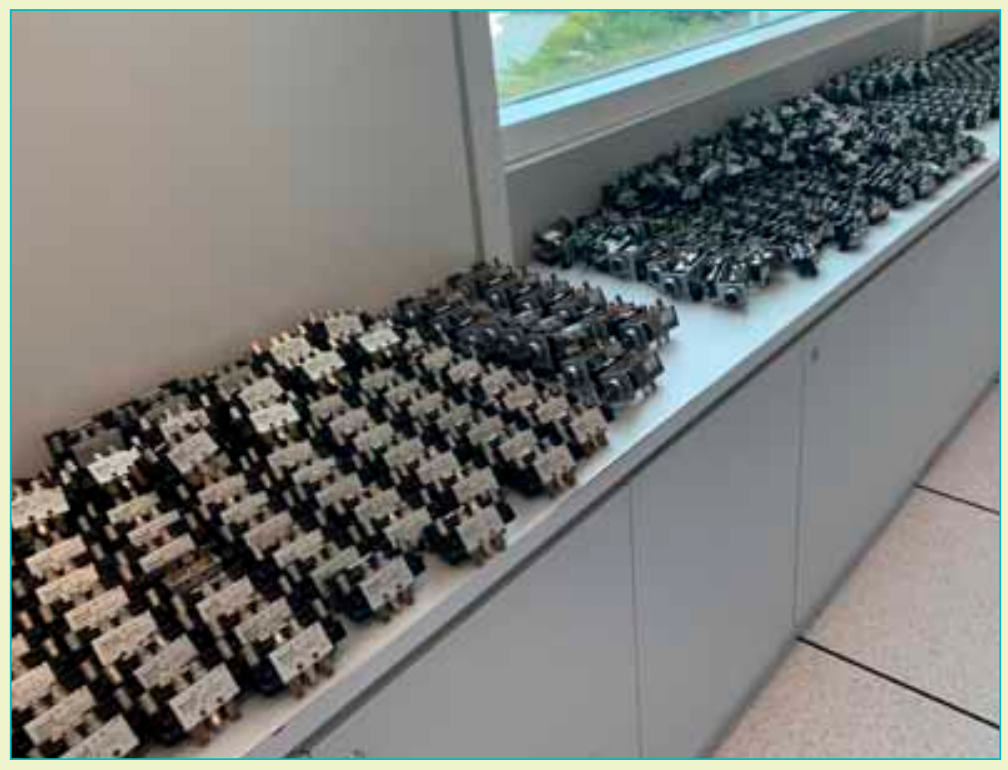

Training kits. Components for programmable logic controller. 


\section{MECHATRONICS TRAINING FACILITIES}

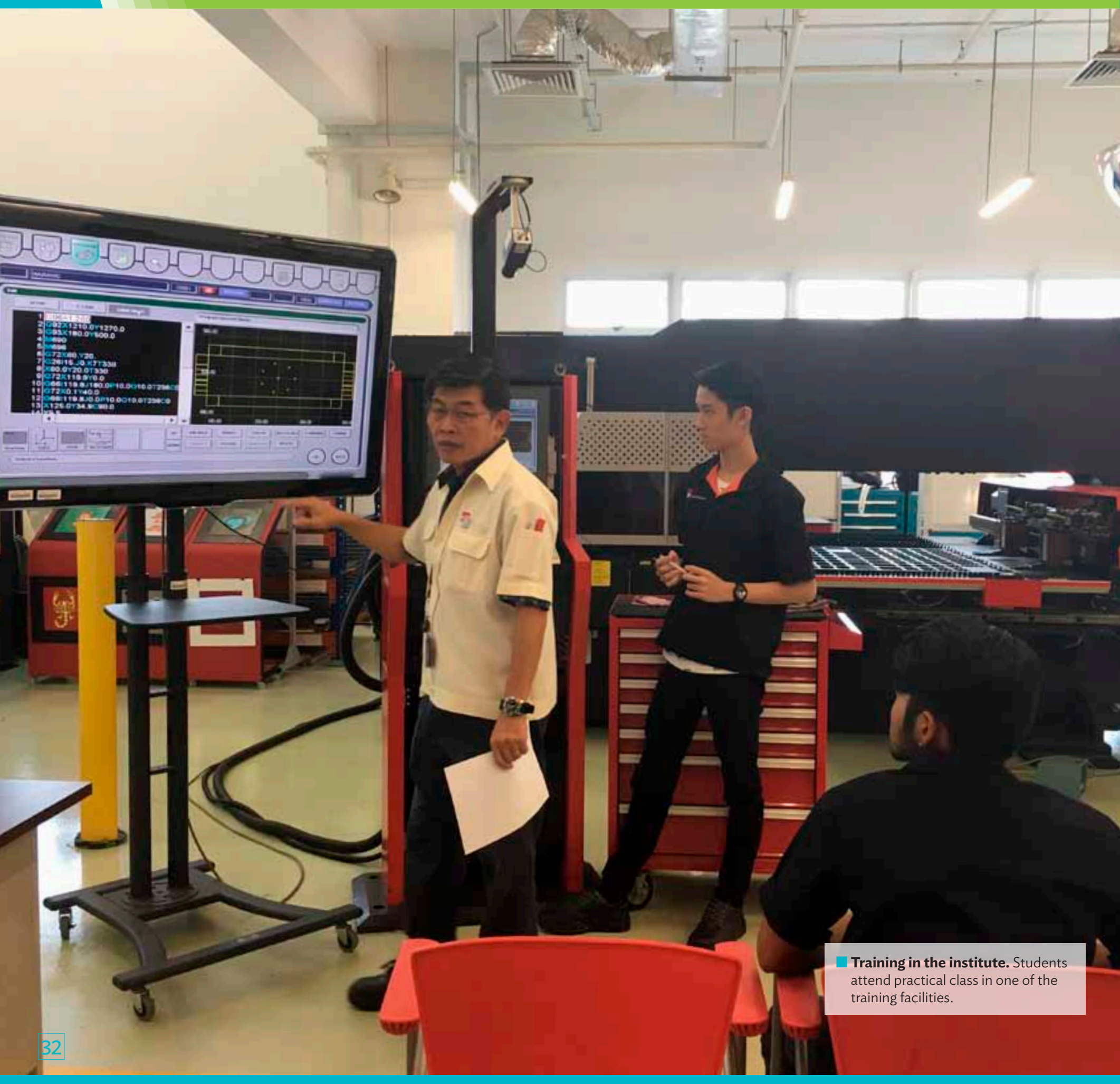




\subsubsection{Training Facility Norms}

\section{A. WORKSHOP FLOOR PLAN LAYOUT AND SIZE}

Figure 5: Layout of Modular Manufacturing System Laboratory

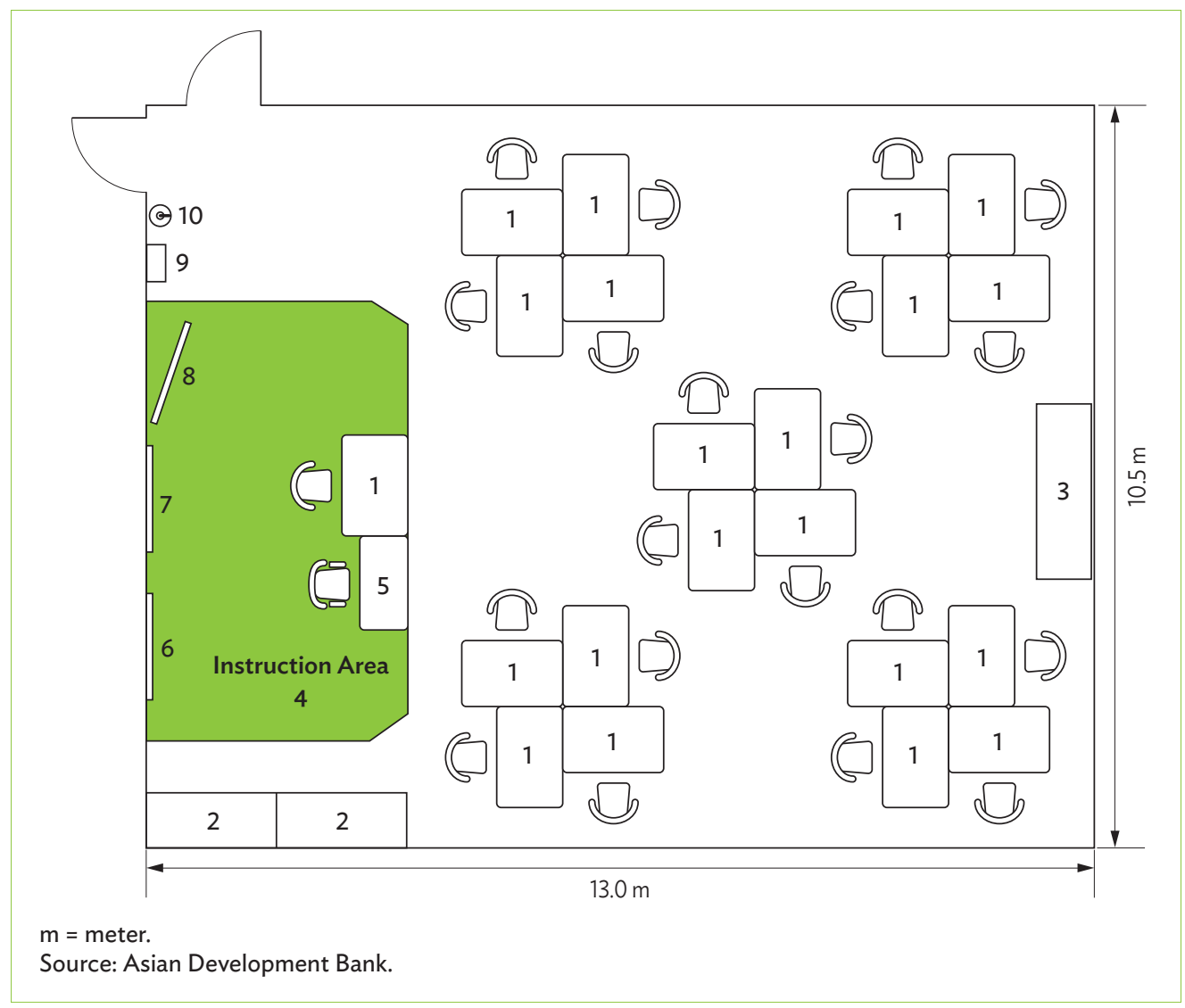

Table 13: Floor Area Requirement for Modular/Flexible Manufacturing System Laboratory

\begin{tabular}{|c|c|c|c|c|}
\hline $\mathbf{S} / \mathbf{N}$ & Item & Quantity & Dimensions & Area \\
\hline 1 & Modular manufacturing system training area & 1 & $10.5 \mathrm{~m} \times 10.0 \mathrm{~m}$ & $105.0 \mathrm{~m}^{2}$ \\
\hline 2 & Network printer & 2 & - & - \\
\hline 3 & Storage cabinet & 1 & - & - \\
\hline 4 & Instructional area & 1 & $6.5 \mathrm{~m} \times 3.0 \mathrm{~m}$ & $19.5 \mathrm{~m}^{2}$ \\
\hline 5 & Trainer's table and chair set & 1 & - & - \\
\hline 6 & Ceiling projector & 1 & - & - \\
\hline 7 & Projector screen & 1 & - & - \\
\hline 8 & Whiteboard & 1 & - & - \\
\hline 9 & First aid kit & 1 & - & - \\
\hline 10 & Fire extinguisher & 1 & - & - \\
\hline
\end{tabular}

$-=$ not applicable, $m=$ meter, $m^{2}=$ square meter.

Source: Asian Development Bank. 


\section{B. TECHNICAL SPECIFICATIONS FOR THE WORKSHOP}

Table 14: Laboratory and/or Workshop for Modular/Flexible Manufacturing System Laboratory

\section{Name of the Laboratory and/or Workshop MODULAR MANUFACTURING SYSTEM LABORATORY \\ Proposed Student Enrollment Size \\ 20 \\ Applicable Field of Usage \\ MECHANICAL TECHNOLOGY AND MECHATRONICS TECHNOLOGY}

\begin{tabular}{|c|c|}
\hline Parameter & Norm \\
\hline $\begin{array}{l}\text { Size of Laboratory and/ } \\
\text { or Workshop }\left(\mathrm{m}^{2}\right)\end{array}$ & $10.5 \mathrm{~m} \times 13 \mathrm{~m} \times \mathbf{4} \mathrm{m}$ (length $\times$ width $\times$ height) \\
\hline $\begin{array}{l}\text { Electrical Loading } \\
\text { Requirement }\end{array}$ & $\begin{array}{l}\text { Four } 16 \mathrm{~A} \text { twin-socket electrical outlet should be provided for each modular } \\
\text { manufacturing system } \\
1216 \mathrm{~A} \text { electrical socket outlet should be provided for general use in the } \\
\text { laboratory } \\
\text { All electrical installation should comply with local regulations } \\
\text { Two emergency stop-buttons should be provided }\end{array}$ \\
\hline $\begin{array}{l}\text { Floor Loading } \\
\text { Requirement }\end{array}$ & $350 \mathrm{~kg} / \mathrm{m}^{2}$ \\
\hline $\begin{array}{l}\text { Lighting Requirement } \\
\text { (Lumen) }\end{array}$ & $\begin{array}{l}\text { Standard ceiling flourescent lightings at } 25 \mathrm{~W} / \mathrm{m}^{2} \\
\text { Emergency lights }\end{array}$ \\
\hline Flooring Requirement & $\begin{array}{l}\text { Raised flooring to facilitate wire cabling from below floor } \\
\text { Vinyl composition to reduce dust and improve electrical insulation }\end{array}$ \\
\hline $\begin{array}{l}\text { Location of Laboratory } \\
\text { and/or Workshop } \\
\text { (Floor) }\end{array}$ & Any floor \\
\hline $\begin{array}{l}\text { Laboratory and/or } \\
\text { Workshop Climatic } \\
\text { Condition }\end{array}$ & Air-conditioned \\
\hline $\begin{array}{l}\text { Building Safety Code } \\
\text { Requirement }\end{array}$ & Comply with national safety code requirements \\
\hline Door Width & At least $1.5 \mathrm{~m}$ wide \\
\hline First Aid Requirement & Adhering to building safety code \\
\hline $\begin{array}{l}\text { Storage Area } \\
\text { Requirement }\end{array}$ & One storage cabinet \\
\hline $\begin{array}{l}\text { Built-in Furniture } \\
\text { Requirement }\end{array}$ & Not applicable \\
\hline
\end{tabular}

Requirement

$\mathrm{A}=$ ampere, $\mathrm{kg}=$ kilogram, $\mathrm{m}=$ meter, $\mathrm{m}^{2}=$ square meter, $\mathrm{W}=$ watt.

Source: Asian Development Bank. 


\subsubsection{Standard Equipment List}

Table 15: Modular/Flexible Manufacturing System Laboratory Equipment Specification

\begin{tabular}{ll} 
Name of the Laboratory and/or Workshop & MODULAR MANUFACTURING SYSTEM WITH ROBOTICS LABORATORY \\
\hline Proposed Student Enrollment Size & 20 \\
\hline Applicable Field of Usage & MECHATRONIC, MECHANICAL, ELECTRONICS, AND ELECTRICAL
\end{tabular}

S/N Name of Item

A Training Equipment / Machine: $\$ 425,000.00$

1 Modular Manufacturing System with Robotics

Modular manufacturing system com
the following stations:
Distributing with HMI
Robot stations with sub-modules
Sorting with HMI
Topics Covered:
Distributing
Conveying
Detection
Robotics
Separating
Joining

5 sets

Complete with operator interface technical data

Operating pressure: (6 bar)

Power supply: $24 \mathrm{~V} \mathrm{DC}$

Square/round workpiece dimensions: minimum $40 \mathrm{~mm}$

6 digital sensors

4 digital actuators

Aluminum profile plate, minimum $700 \times 350 \mathrm{~mm}$, with cable guide

Conveyor module, minimum $350 \times 40 \mathrm{~mm}$, DC

Stacking magazine module, without workpiece holder

Start-up valve with filter control valve

Cable holder with hook-and-loop fastener more than 10 sets

C-interface

Quick-fix clamping adapter

Control console

PLC Trainer CPU 314C-2PN/DP

5 units

192 KB RAM for program and data

5 units Includes MMC

Interfaces: at least three

Inputs/outputs: 24 digital inputs (24 V DC); 16 digital outputs

(24 V DC, $500 \mathrm{~mA}$ )

4 analog inputs, 12 bit, $20 \mathrm{~ms},( \pm 10 \mathrm{~V}, 0-10 \mathrm{~V}, \pm 20 \mathrm{~mA}$,

0/4-20 mA), 1 Pt100 input

2 analog outputs, ( $\pm 10 \mathrm{~V}, 0-10 \mathrm{~V}, \pm 20 \mathrm{~mA}, 0 / 4-20 \mathrm{~mA})$

$\mathrm{I} / \mathrm{O}$ data cable connectors (IEEE 488), minimum $2 \mathrm{~m}$

Analog cable, parallel, minimum $2 \mathrm{~m}$

Safety laboratory cable, minimum $3 \mathrm{~m}$

IEC power cable $90^{\circ}$

PC adapter, USB

Programming software for above PLC

School license 
Table 15 continued

S/N Name of Item

Digital simulation box

Light barrier with holder and sleeves

5/2-way single solenoid valve, including minimum $1 \mathrm{~m}$ valve cable

Textbook: Basic Principles of Pneumatics and Electro-Pneumatics

Workbook: Conveyor Module Basic Level

Design and simulation software for PLC and sensors
Quantity Remarks

5 units

5 units

5 units

20 sets

20 sets

School license

\section{b Robot Station with Module}

Technical data:

Power supply: 230 VAC, $50 / 60 \mathrm{~Hz}$.

Operating pressure: 6 bar

Maximum workpiece width: minimum $40 \mathrm{~mm}$

12 digital inputs

5 digital outputs

Trolley height (including castors, to bottom edge of profile plate):

minimum $750 \mathrm{~mm}$, width: $700 \mathrm{~mm}$, depth: $700 \mathrm{~mm}$

Extruded aluminum profile plate minimum $700 \times 700 \mathrm{~mm}$

Safety housing minimum $700 \times 700 \mathrm{~mm}$ complete with the safety door is equipped with a safety switch. Supplied as a kit with detailed assembly instructions.

Control console allows simpler operation of the multimedia messaging service with robotics station. Fully assembled with operating panel, communication panels, spare panel, and mounting frame with suitable connector

Membrane keyboard: Start push-button with LED, stop push-button, reset push-button with LED, 2 flexibly assignable control lamps

$4 \mathrm{~mm}$ safety sockets with LED status display for simple I/O connection. I/O sub-D sockets for connection to PLC

Tabletop power supply unit with below specification: Input voltage: $230 \mathrm{VAC}(50-60 \mathrm{~Hz})$

Output voltage: $24 \mathrm{~V} \mathrm{DC}$, short-circuit-proof

Output current: minimum $4 \mathrm{~A}$

Robot handling module technical data as below:

Power supply: $24 \mathrm{~V} \mathrm{DC}$

Maximum workpiece width: minimum $40 \mathrm{~mm} 2$ digital inputs

Workpiece set "cylinder bodies"

Workpiece set "for cylinder assembly"

C interface

15-pin D-sub cables: plug connector-plug connector

I/O data cable with connectors (IEEE 488)

Robot assembly module technical data

Operating pressure max: 6 bar

Power supply: $24 \mathrm{~V} \mathrm{DC}$

8 digital inputs

3 digital outputs

Robot interface box - Add-on for robot station. Up to 16 robot controller I/Os can be distributed to 4 sockets with the Robot interface box. The robot interface box is connected to the robot controller's I/O card via a 50 -pin centronics connector. On the front panel are LEDs to display the status of the robot I/Os. On the rear panel are 4 sockets for connection to peripherals

Graphical operator terminal - The graphical operator terminal allows the robot to be controlled via an intuitive user interface with touchscreen. All screen content of the high-resolution TFT display with 65536 colors is freely programmable using the supplied PC software. An ethernet connection is used for communication with the robot controller

Robot - With teachbox and cripper, pneumatic, high-precision, 6-axis articulated arm robot with gear units and brakes on all axes. Complete with control unit, programming cable, battery set, and a standard handheld terminal. 
Gripper, pneumatic, pneumatic parallel gripper for mounting on the robot arm - complete with gripper jaws, sensor with fiber-optic cable and accessories

Start-up valve with filter control valve filter control valve with pressure gauge and start-up valve mounted on adapter with adjustable angle. The start-up valve pressures and/or exhausts the connected pressure zone. Design: sintered filter with water separator and piston regulator.

Flowrate: 120 liters/minute

Pressure regulation range: $(0,5-10 \mathrm{bar})$

Grade of filtration: $5 \mu \mathrm{m}$

Fitting: $\mathrm{G} 1 / 8 \times 6 \mathrm{~mm}$ OD

Sorting station with operator interface

General technical data:

Operating pressure: 6 bar

Power supply: $2 \times 24 \mathrm{~V} \mathrm{DC} /$ minimum $4.0 \mathrm{~A}$

Square/round workpiece

Dimensions: maximum $40 \mathrm{~mm}$

5 digital sensors

1 digital actuator

Textbook: Fundamentals of Stepper Motor Drive Technology

Design and simulation software for PLC, motors, electro-pneumatics, and drive

Control console

PLC Trainer CPU 314C-2PN/DP

192 KB RAM for program and data includes MMC

Interfaces: at least three

Inputs/outputs: 24 digital inputs (24 V DC), 16 digital outputs

(24 V DC, $500 \mathrm{~mA}$ )

4 analog inputs, 12 bit, $20 \mathrm{~ms},( \pm 10 \mathrm{~V}, 0-10 \mathrm{~V}, \pm 20 \mathrm{~mA}, 0 / 4-20 \mathrm{~mA})$,

1 Pt100 input

2 analog outputs, $( \pm 10 \mathrm{~V}, 0-10 \mathrm{~V}, \pm 20 \mathrm{~mA}, 0 / 4-20 \mathrm{~mA})$

$\mathrm{I} / \mathrm{O}$ data cable with connectors (IEEE 488), minimum $2 \mathrm{~m}$

Analog cable, parallel, $2 \mathrm{~m}$

Safety laboratory cable, $3 \mathrm{~m}$

IEC power cable $90^{\circ}$

PC adapter, USB

PLC programming software

Digital simulation box

\section{Integrated HMI Module}

Operator interface

Screen diagonal: 9 inches

Display: TFT widescreen display, 16 million colors

Resolution: $800 \times 480$ pixels

Control elements: Touch screen 10 keys

Interfaces: Ethernet for profinet, $1 \times$ USB host, $1 \times$ SD slot

Protection rating: IP65

Power supply for fast reconnection: Maintenance free energy storage

with a capacity of up to 5 minutes

Drop test: Withstands the shock of a fall up to $1.2 \mathrm{~m}$

Safety technology: F-variant with illuminated stop button, 3-step enabling switch with distinct physical advise
20 sets

School license

5 units

5 units
School license 5 units

20 units

(10 for

distributing

and 10 for

sorting) 
Table 15 continued

Software specification

Configuration software: Win CC comfort

Messages: 4,000

Message classes: 32

Process screens: 500

Tags: 2,048

Recipes: 300

Archives: 50

Visual basic scripts: 100

Connection cable for power

Connection cable to interface to PLC

All accessories to make the complete system fully functional such as power

supply. Connectors and HMI stand

\section{Trainers' Training should be provided}

B Tools and Accessories

\begin{tabular}{|c|c|c|}
\hline & $\begin{array}{l}\text { Workpiece set } \\
\text { Battery set for robot } \\
\text { Workpiece set "for cylinder assembly" } \\
\text { Programming instructions for robot } \\
\text { Technical manual for robot } \\
\text { Compressor: Screw-type, portable, low-noise, } 45 \mathrm{db}\end{array}$ & $\begin{array}{l}5 \text { sets } \\
5 \text { sets } \\
10 \text { sets } \\
\text { (with spares) } \\
5 \text { units } \\
5 \text { units } \\
5 \text { units }\end{array}$ \\
\hline \multicolumn{3}{|c|}{ C Furniture } \\
\hline & Trainer's table and chair set & 1 unit \\
\hline & Students' chairs & 20 sets \\
\hline & Screen & 1 unit \\
\hline & Whiteboard & 1 unit \\
\hline & Projector (liquid crystal display) & 1 unit \\
\hline
\end{tabular}

$\mathrm{A}=$ ampere, $\mathrm{CPU}=$ central processing unit, $\mathrm{dB}=$ decibel, $\mathrm{DC}=$ direct current, $\mathrm{DP}=$ display port or decentralized peripherals, $\mathrm{HMI}=$ human machine interface, $\mathrm{Hz}=$ hertz, IEC = International Electrotechnical Commission, IEEE = Institute of Electrical and Electronics Engineers, $\mathrm{I} / \mathrm{O}=$ input/output, $\mathrm{IP}=$ international protection marking, $\mathrm{KB}=$ kilobyte, $\mathrm{LED}=$ light-emitting diode, $\mathrm{m}=\mathrm{meter}$, $\mathrm{mA}=$ milliampere, $\mathrm{mm}=$ millimeter,$\mu \mathrm{m}=$ micrometer, $\mathrm{MMC}=$ multimedia card, $\mathrm{OD}=$ outside diameter, $\mathrm{PC}=$ personal computer, $\mathrm{PLC}=$ programmable logic controller, $\mathrm{PN}=$ profinet, $\mathrm{Pt}=$ platinum resistance thermometer, $\mathrm{SD}=$ secure digital, $\mathrm{TFT}=$ thin-film-transistor, $\mathrm{V}=$ volt, $\mathrm{VAC}=$ voltage in alternating current, $\mathrm{VDC}=$ voltage direct current

Source: Asian Development Bank. 


\subsubsection{Sample Photos for Mechatronics Laboratory}

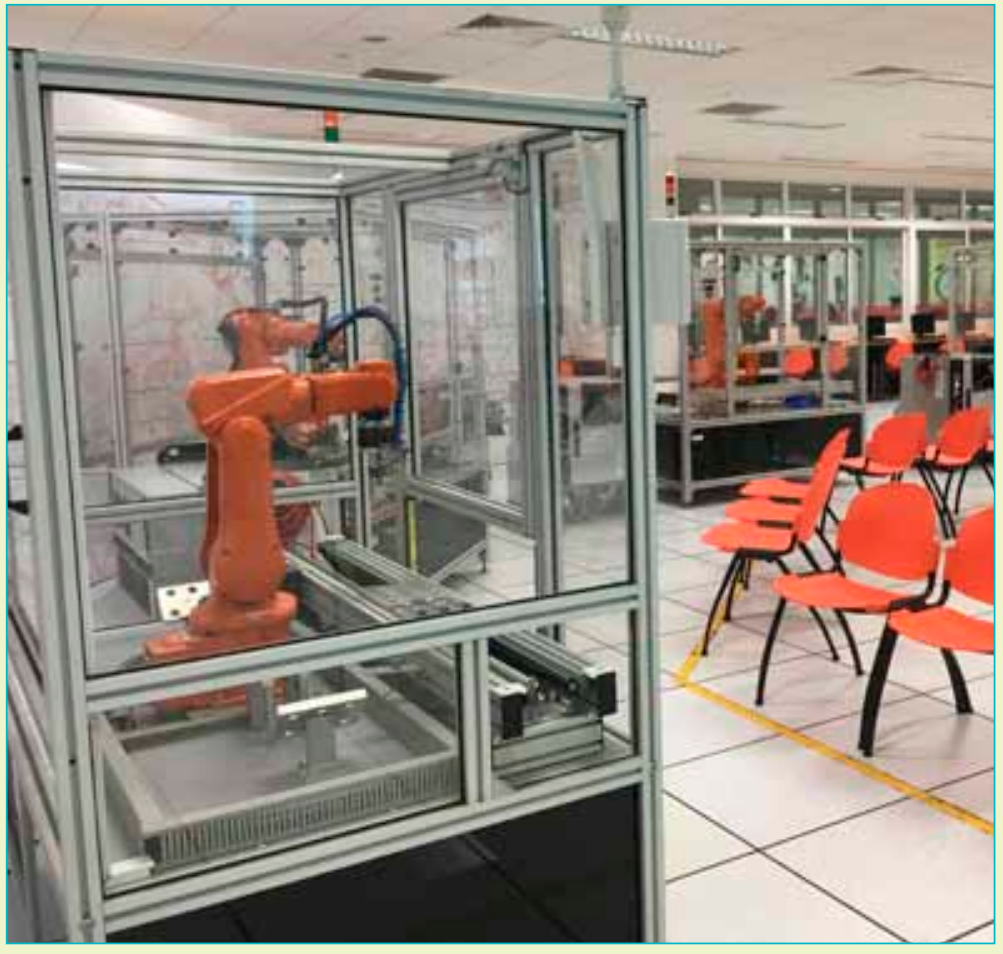

Robotics laboratory. Robotics laboratory for practical training.

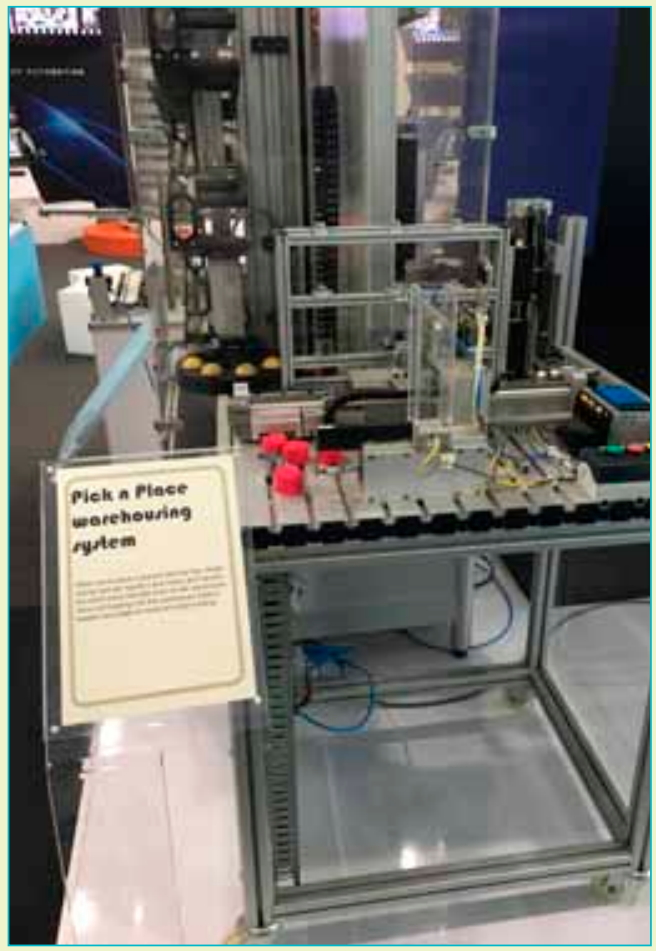

Flexible manufacturing system. Pick-and-place warehousing system.

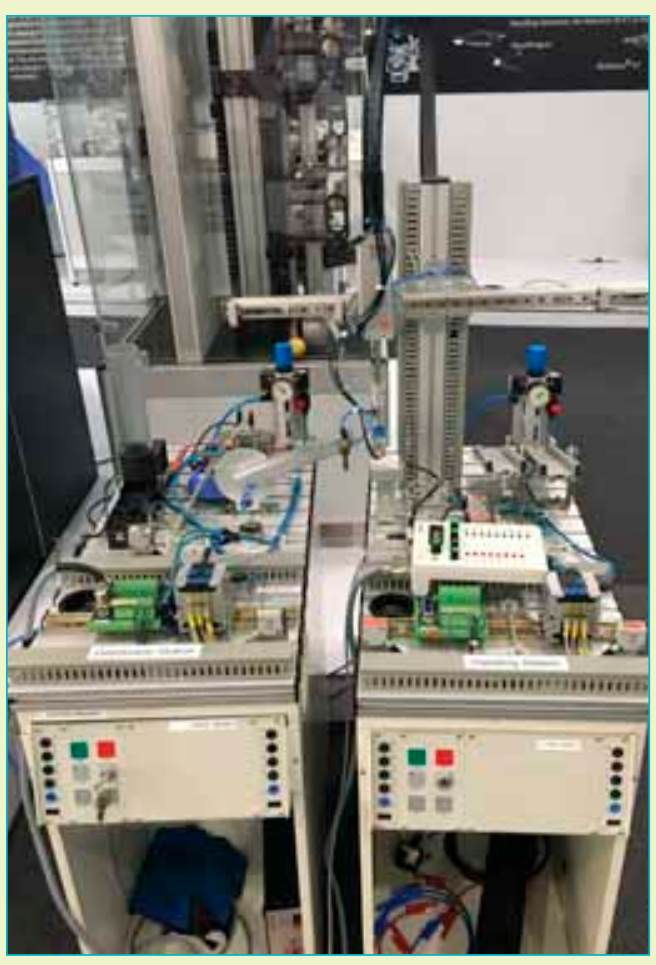

Flexible manufacturing system. Sorting station.

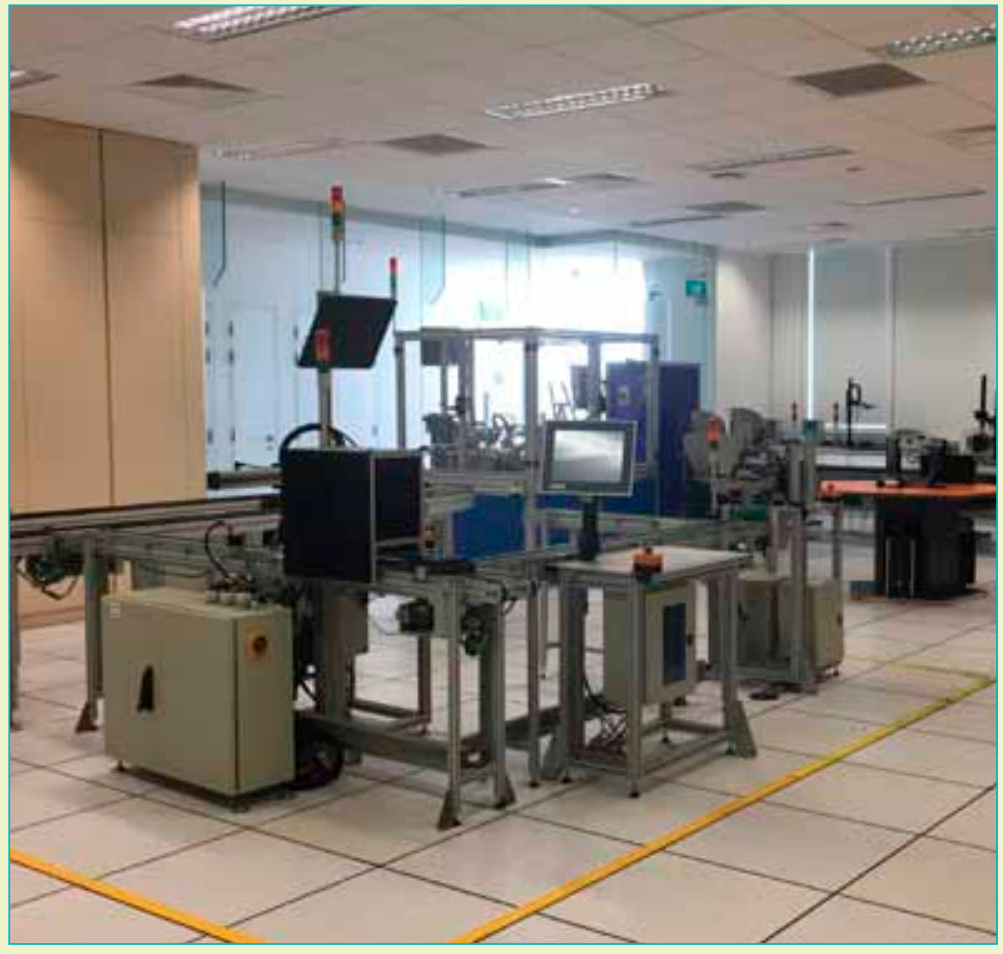

Flexible manufacturing system. Complete set of flexible manufacturing system. 


\section{PROGRAMMABLE LOGIC CONTROLLER, SENSOR, AND VISION LABORATORY}

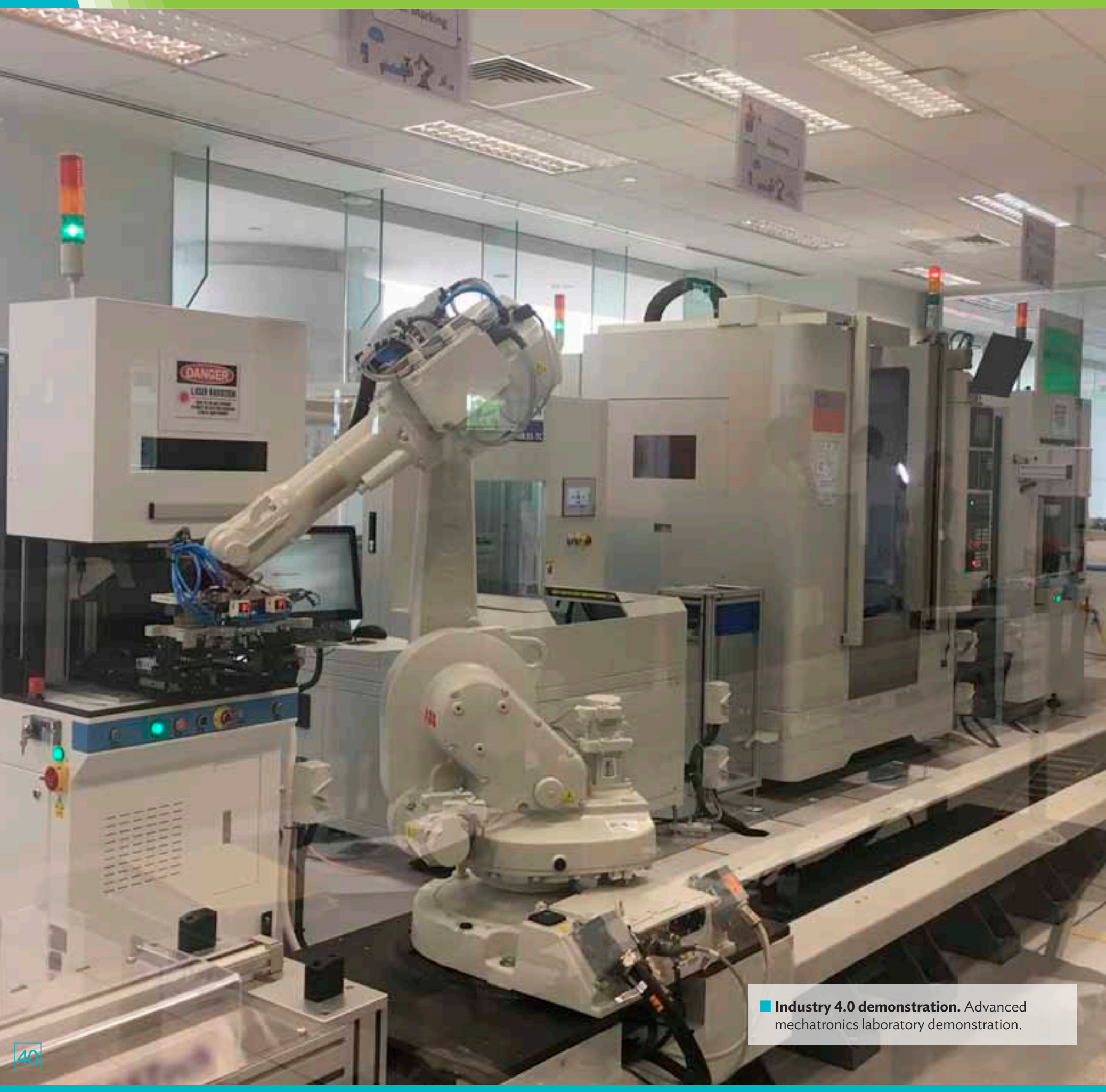




\subsubsection{Training Facility Norms}

\section{A. WORKSHOP FLOOR PLAN LAYOUT AND SIZE}

Figure 6: Layout of Programmable Logic Controller, Sensor, and Vision Laboratory

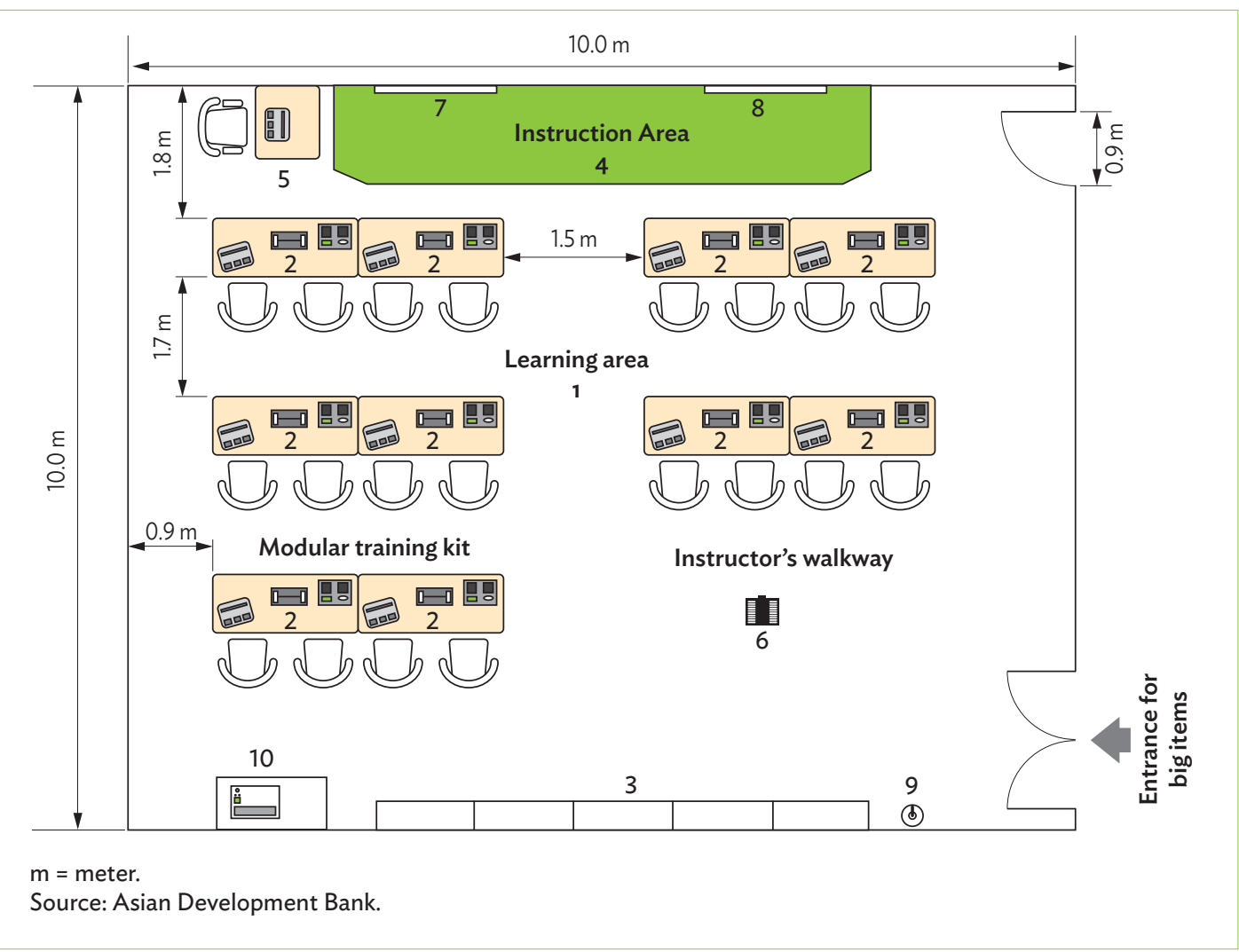

Table 16: Floor Area Requirement for Programmable Logic Controller, Sensor, and Vision Laboratory

\begin{tabular}{llccc}
\hline S/N & \multicolumn{1}{c}{ Item } & Quantity & Dimensions & Area \\
1 & Student learning area & 1 & $8.2 \mathrm{~m} \times 10 \mathrm{~m}$ & $82 \mathrm{~m}^{2}$ \\
\hline 2 & Students' workbench with chair & 10 or 20 & - & - \\
3 & Storage cabinet & 5 & - & - \\
\hline 4 & Instruction area & 1 & $1.8 \mathrm{~m} \times 10 \mathrm{~m}$ & $18 \mathrm{~m}^{2}$ \\
\hline 5 & Teacher's table and chair set & 1 & - & - \\
\hline 6 & Ceiling projector & 1 & - & - \\
\hline 7 & Whiteboard & 1 & - & - \\
\hline 8 & Projector screen & 1 & - & - \\
\hline 9 & Fire extinguisher & 1 & - & - \\
\hline 10 & Network printer & 1 & - & - \\
\hline
\end{tabular}

$-=$ not applicable, $m=$ meter, $\mathrm{m}^{2}=$ square meter.

Source: Asian Development Bank. 


\section{B. TECHNICAL SPECIFICATIONS FOR THE WORKSHOP}

Table 17: Laboratory and/or Workshop for Programmable Logic Controller, Sensor, and Vision Laboratory

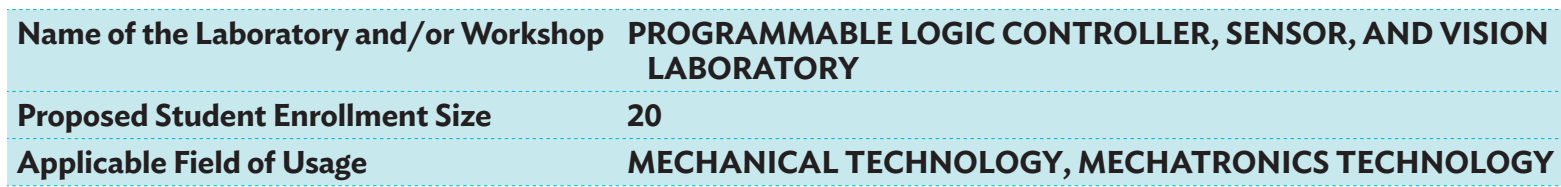

\begin{tabular}{|c|c|c|}
\hline Parameter & Norm & Remarks \\
\hline Size of Laboratory and/or Workshop & $10 \mathrm{~m} \times 10 \mathrm{~m} \times \mathbf{4} \mathrm{m}$ (length $\times$ width $\times$ height $)$ & \\
\hline Electrical Loading Requirement & $\begin{array}{l}\text { Two 16A twin socket electrical outlet should be provided for each } \\
\text { computer table } \\
1216 \mathrm{~A} \text { electrical socket outlets should be provided for general } \\
\text { use in the laboratory } \\
\text { All electrical installation should comply with local regulations } \\
\text { Two emergency stop-buttons should be provided }\end{array}$ & \\
\hline Floor Loading Requirement & $350 \mathrm{~kg} / \mathrm{m}^{2}$ & \\
\hline Lighting Requirement (Lumen) & $\begin{array}{l}\text { Standard ceiling flourescent lightings at } 25 \mathrm{~W} / \mathrm{m}^{2} \\
\text { Emergency lights }\end{array}$ & \\
\hline Flooring Requirement & $\begin{array}{l}\text { Raised flooring to facilitate wire cabling from below floor } \\
\text { Vinyl composition to reduce dust and improve electrical insulation }\end{array}$ & \\
\hline $\begin{array}{l}\text { Location of Laboratory } \\
\text { and/or Workshop (Floor) }\end{array}$ & Any floor & \\
\hline $\begin{array}{l}\text { Laboratory and/or Workshop } \\
\text { Climatic Condition }\end{array}$ & Air-conditioned & \\
\hline Building Safety Code Requirement & Comply with national safety code requirements & \\
\hline Door Width & At least $1.5 \mathrm{~m}$ wide & \\
\hline First Aid Requirement & Adhering to building safety code & \\
\hline Storage Area Requirement & Five storage cabinet & \\
\hline Built-in Furniture Requirement & Not applicable & \\
\hline
\end{tabular}

$\mathrm{A}=$ ampere, $\mathrm{kg}=$ kilogram, $\mathrm{m}=$ meter, $\mathrm{m}^{2}$ = square meter, $\mathrm{W}=$ watt.

Source: Asian Development Bank. 


\subsubsection{Standard Equipment List}

Table 18: Programmable Logic Controller, Sensor, and Vision Laboratory Equipment Specification

\begin{tabular}{|c|c|}
\hline Name of the Laboratory and/or Workshop & $\begin{array}{l}\text { PROGRAMMABLE LOGIC CONTROLLER, SENSOR, AND VISION } \\
\text { LABORATORY }\end{array}$ \\
\hline Proposed Student Enrollment Size & 20 \\
\hline Applicable Field of Usage: & MECHATRONICS, ELECTRONICS, ELECTRICAL \\
\hline
\end{tabular}

S/N Name of Item

Description of Item

Quantity

Remarks

A Training Equipment / Machine: $\$ 600,000.00$

1 PLC Trainer Modular programmable logic controller with universal analog input and analog output interface cards module, digital output module, and digital input module

Modular architecture for future expansion (analog, fieldbus)

Program capacity of up to $3 \mathrm{MB} / 60 \mathrm{k}$ steps

Retentive data memory capacity up to $0.5 \mathrm{MB}$

Support up to $2,560 \mathrm{I} / \mathrm{O}$ points

Able to process floating point instruction within 0.86 microseconds

Built in USB port $\times 1$

Built-in ethernet/IP port $\times 1$

Tag data links (program-less data exchange)

$\mathrm{CIP}$ message communication functions

Socket services

FTP server

FTP client

Automatic clock synchronization

SNMP agent

Data base connection function for Internet of Things

Microsoft corporation: SQL Server 2008/2008

R2/2012/2014

Oracle corporation: Oracle database $10 \mathrm{~g} / 11 \mathrm{~g} / 12 \mathrm{c}$

MySQL community edition 5.1/5.5/5.6

IBM: DB2 for Linux, UNIX and Windows 9.5/9.7/10.1/10.5

Firebird foundation incorporated: Firebird 2.1/2.5

The PostgreSQL Global Development Group: PostgreSQL

$$
\text { 9.2/9.3/9.4 }
$$

Built-in ethercat port $\times 1$ (For connection to inverters or servo

drives)

OLE for process control connectivity

Support ethercat communication for distributed I/O control

Support ladder program, structured text, and function block programing

Available function block libraries for communication such as MODBus, TCP/IP Socket, etc.

a Analog to Digital Converter Module

20 sets

To be connected to PLC CPU communication bus directly

4 analog inputs

Separate configuration for individual inputs

Fully universal inputs:

Pt100

JPt 100

Pt 1,000

Type K, J, T, L, R, S, or B thermocouple

4 to $20 \mathrm{~mA}$

0 to $20 \mathrm{~mA}$

1 to $5 \mathrm{~V} / 0$ to $5 \mathrm{~V} / 0$ to $10 \mathrm{~V}$ 
Table 18 continued

S/N Name of Item

\section{Accuracy:}

b Digital to Analog Converter Module

To be connected to PLC CPU communication bus directly

4 analog outputs

Separate configuration for individual outputs

Support analogue signal

Resolution: Up to 1/4,000

conversion period: Up to $250 \mu \mathrm{s} /$ point

c Digital Output Module

To be connected to PLC CPU

16 relay contact outputs

Maximum switching capacity: 250 VAC/24VDC, 2A

d Digital Input Module

To be connected to PLC CPU

16 Inputs

Input voltage: $24 \mathrm{VDC}$

Input current: $10 \mathrm{~mA}$

PLC stand

The PLC must be mounted onto a standing platform and/or panel

The platform should be tilted at an appropriate angle to allow ease

of wiring

The platform should come with necessary wiring to power up the

PLC

The platform should come with 24 VDC power supply

The 24 VDC power supply should be DIN mounted, with finger

guards on the wiring terminals

The 24 VDC power supply should not have metal coverings

The I/Os of the PLC are to be connected to a terminal block

system

The terminal block system should be in such a way that 24 VDC

power is available at individual digital input and output point

Isolation switch must be individual analog input and output

\section{Trainers' Training should be provided}

\section{Sensor Trainer}

Photo electric sensors

Proximity sensors

Capacitive sensor

Strain gauges / load cell

Pressure sensor

Temperature sensors (RTD, thermocouple)

Accelerometer

3 Vision System Trainer

High speed controller with integrated LCD, with 1 camera, PNP output, digital CCD/CMOS camera, 5 million pixels, color, image

Read time: $38.2 \mathrm{~ms}$
Platinum resistance thermometer input: $\pm 0.3 \%$ of $\mathrm{PV}$ or

$\pm 0.8^{\circ} \mathrm{C}$, whichever is larger \pm 1 digit max.

Thermocouple input: $\left( \pm 0.3 \%\right.$ of $\mathrm{PV}$ or $\pm 1.5^{\circ} \mathrm{C}$, whichever is larger) \pm 1 digit max.

Voltage or current input: $\pm 0.3 \%$ of F.S. \pm 1 digit max.

Conversion speed of $250 \mathrm{~ms} / 4$ inputs

20 sets

4 to $20 \mathrm{~mA}$

0 to $20 \mathrm{~mA}$

1 to $5 \mathrm{~V}$

0 to $10 \mathrm{~V}$

-10 to $10 \mathrm{~V}$

20 sets

20 sets

\section{Quantity $\quad$ Remarks}

.

20 units

\section{0 units}

\section{0 units}


Table 18 continued

\section{S/N Name of Item}

Description of Item

\begin{tabular}{l|l} 
Quantity & Remarks \\
\hline
\end{tabular}

\section{B Tools and Accessories}

\begin{tabular}{|c|c|c|c|}
\hline & Bend resistant camera cable $5 \mathrm{~m}$ & 10 pieces \\
\hline & & LED monitor cable & 10 pieces \\
\hline & & $\begin{array}{l}\text { Parallel I/O cable for connector-terminal conversion unit } \\
\text { Connector-terminal block conversion units can be connected }\end{array}$ & 10 pieces \\
\hline & & $\begin{array}{l}\text { Connector-terminal block conversion units, general-purpose } \\
\text { devices }\end{array}$ & 10 pieces \\
\hline & & $\begin{array}{l}\text { Desktop controller stand } \\
\text { For installing the LCD integrated-type and attachment }\end{array}$ & 10 units \\
\hline & & Switch hubs ethernet IP & 10 units \\
\hline & & External lighting & 10 pieces \\
\hline & & Lighting controller & 10 units \\
\hline & & Vibrations and shock resistance $\mathrm{C}$ mount lens & 10 units \\
\hline \multirow{6}{*}{\multicolumn{2}{|c|}{ C Furniture }} & & \\
\hline & & Trainer's table and chair set & 1 set \\
\hline & & Whiteboard 1,500 × 1,000 mm double-sided with castors & 1 unit \\
\hline & & Working table & 10 units \\
\hline & & LCD projector & 1 unit \\
\hline & & Screen & 1 unit \\
\hline
\end{tabular}

$\mathrm{A}=$ ampere, $\mathrm{CCD} / \mathrm{CMOS}=$ charge-coupled device/complimentary metal-oxide semi-conductor, $\mathrm{CIP}=$ common industrial protocol, $\mathrm{CPU}=$ central processing unit, DIN = Deutsches Institut fur Normung (German Institute for Standardization), FTP = file transfer protocol, $F S=$ full scale, IBM = International Business Machines, $I / O=$ input/output, IP = internet protocol, JPt = Japan Industrial Standard (JIS) for Platinum Resistance Thermometer, $L C D=$ liquid crystal display, $L E D=$ light-emitting diode, $m=$ meter, $\mathrm{mA}=$ milliampere, $M B=$ megabyte, $\mathrm{ms}=$ millisecond,$\mu \mathrm{m}=$ micrometer, $\mathrm{OLE}=$ object linking and embedding, $\mathrm{PLC}=$ programmable logic controller, $\mathrm{PNP}=$ positive-negativepositive, $\mathrm{Pt}=$ platinum resistance thermometer, $\mathrm{PV}=$ present value, $\mathrm{RTD}=$ resistance temperature detector, $\mathrm{SNMP}=$ simple network management protocol, $\mathrm{SQL}=$ standardized query language, $\mathrm{TCP} / \mathrm{IP}=$ transmission control protocol/internet protocol, UNIX = uniplexed information and computing system, $\mathrm{V}=$ volt, $\mathrm{VAC}=$ voltage in alternating current, $\mathrm{VDC}=$ voltage direct current.

Source: Asian Development Bank. 
5.1.3 Sample Photos of Programmable Logic Controller, Sensor, and Vision Laboratory

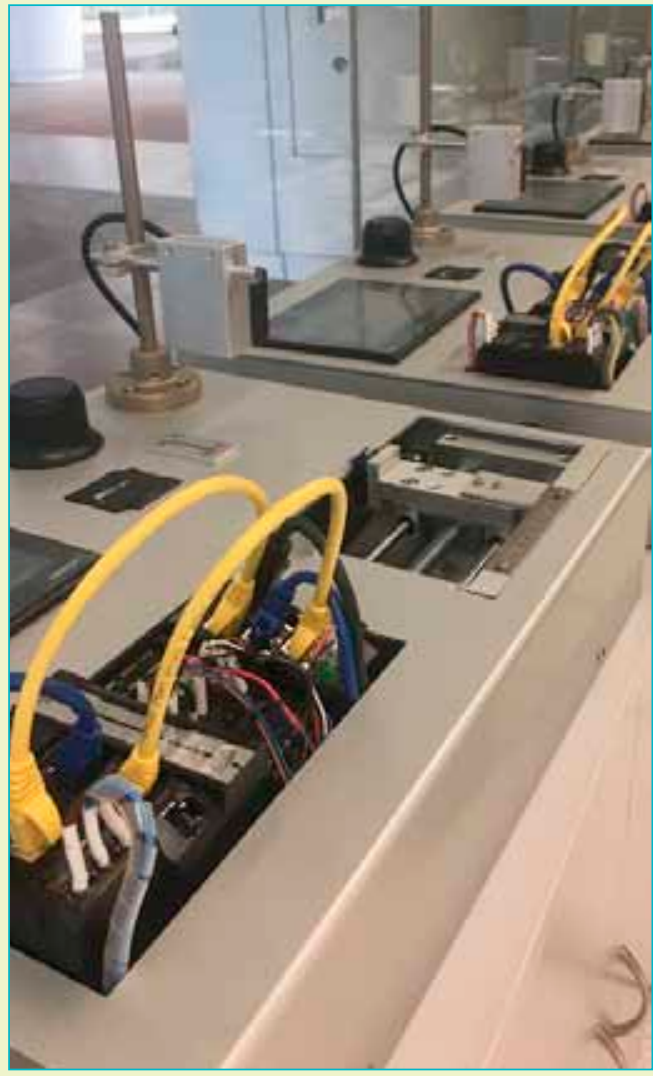

Program logic control. Training unit.

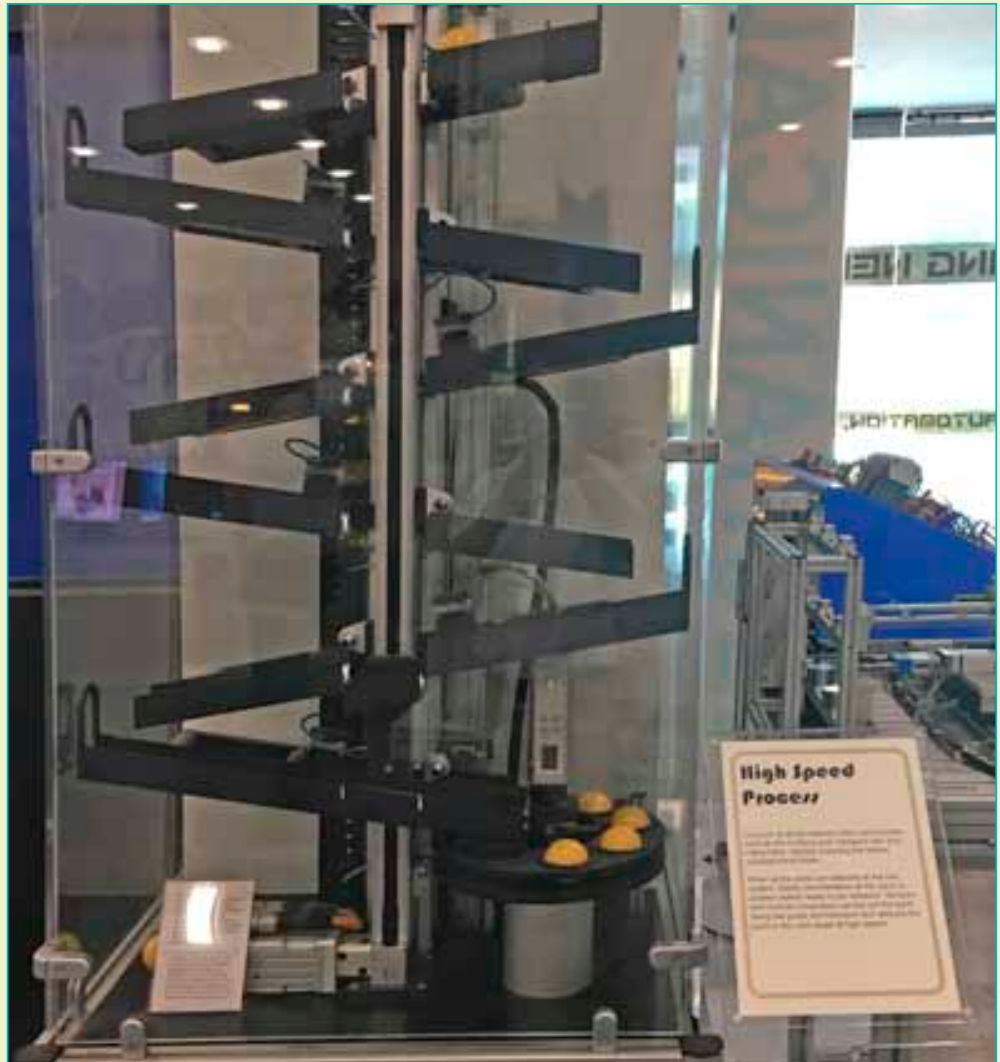

Sensor and control. High-speed process station.

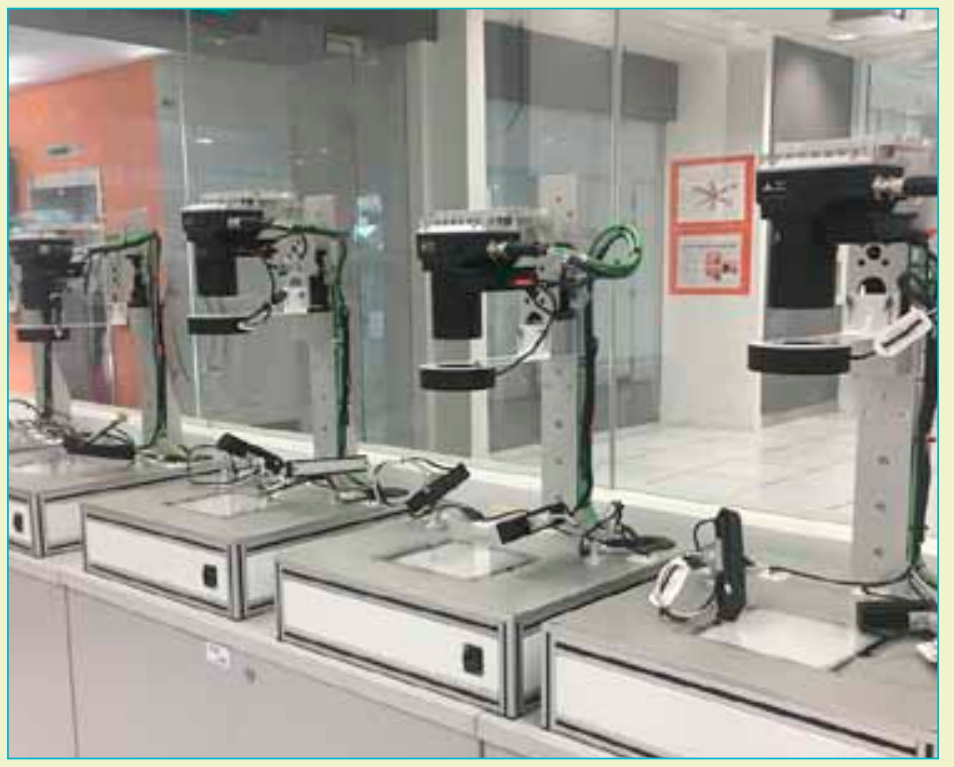

Computer vision. Training unit.

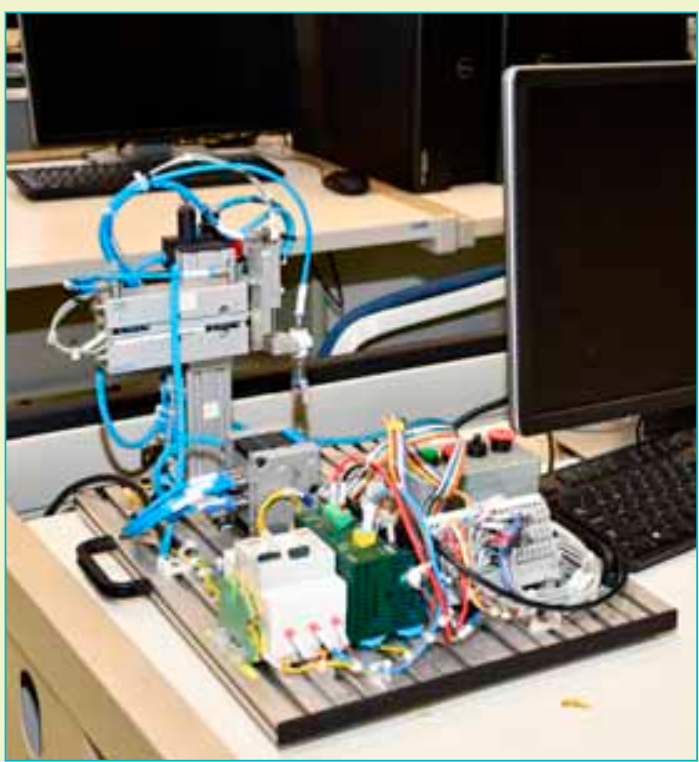

Modular trainer. Programmable logic sensor. 


\section{INDUSTRIAL PROJECT LABORATORY}

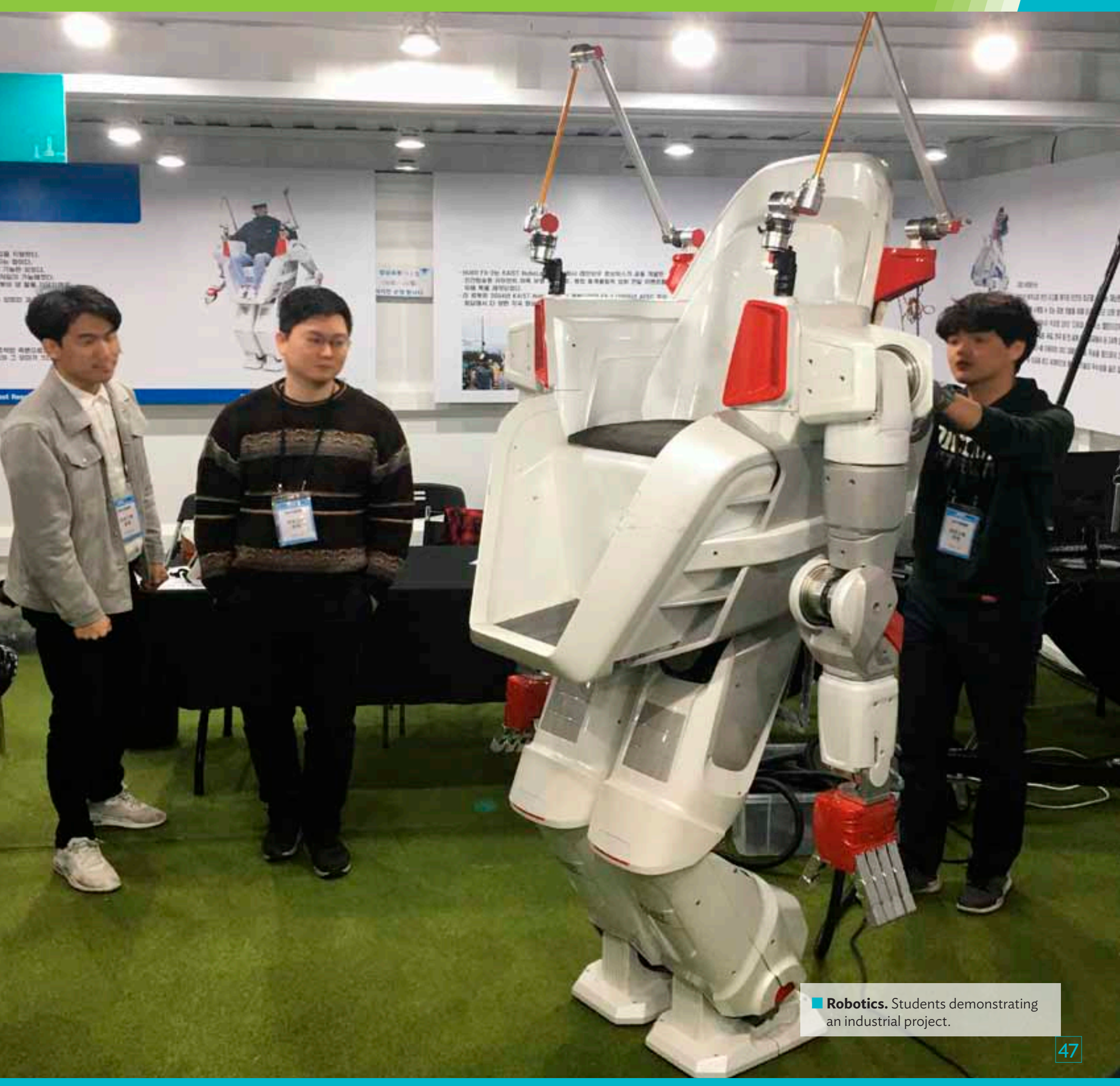




\subsubsection{Training Facility Norms}

\section{A. WORKSHOP FLOOR PLAN LAYOUT AND SIZE}

Figure 7: Layout of Industrial Project Laboratory

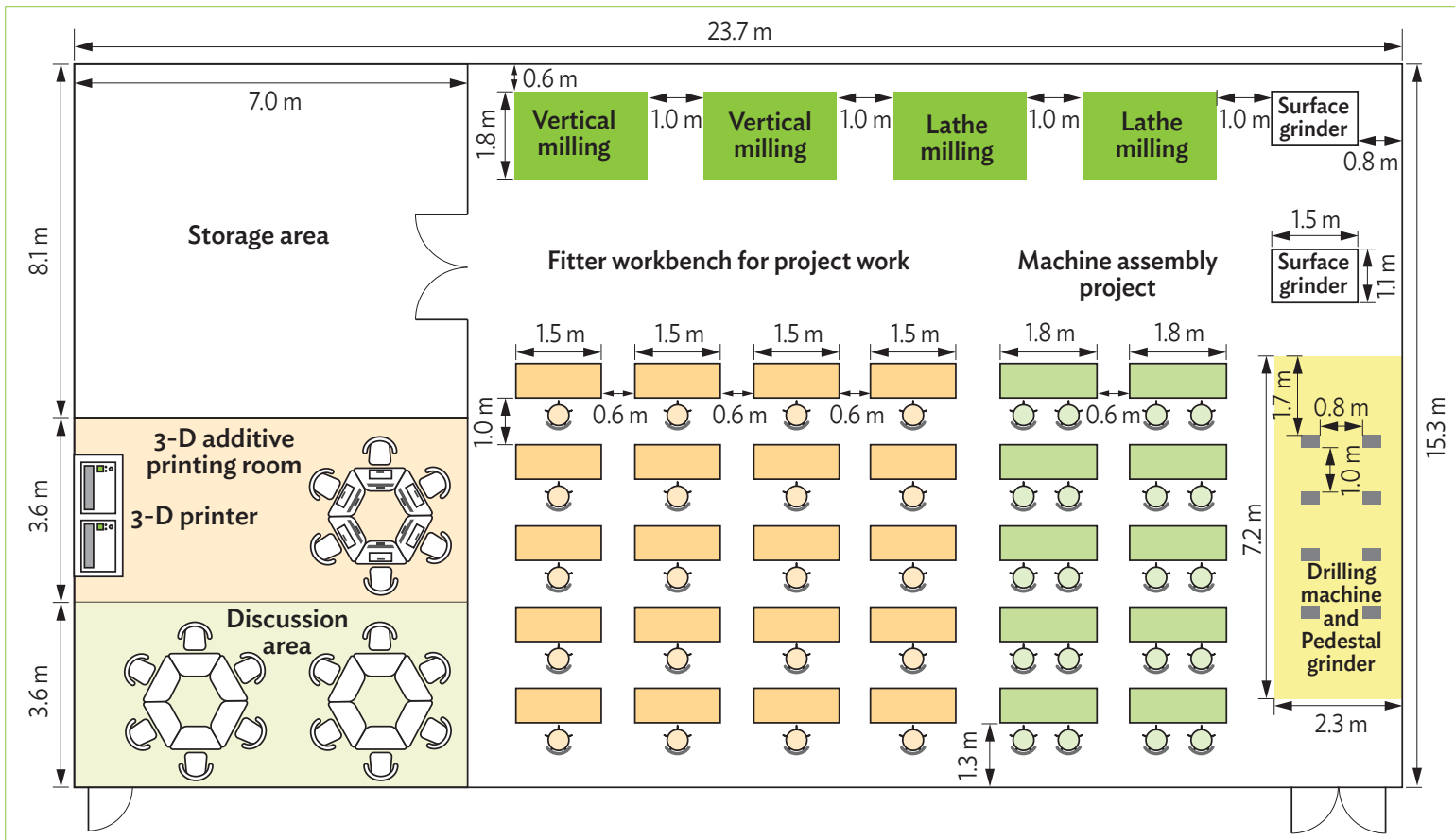

$\mathrm{m}=$ meter.

Source: Asian Development Bank.

Table 19: Floor Area Requirement for Industrial Project Laboratory

\begin{tabular}{|c|c|c|c|c|}
\hline S/N & Item & Quantity & Dimensions & Area \\
\hline 1 & Project work area & 1 & $23.7 \mathrm{~m} \times 15.3 \mathrm{~m}$ & $362.6 \mathrm{~m}^{2}$ \\
\hline 2 & Fitter workbench & 20 & - & - \\
\hline 3 & Machine assembly project & 10 & - & - \\
\hline 4 & Mill machine & 2 & - & - \\
\hline 5 & Turn machine & 2 & - & - \\
\hline 6 & Surface grinder & 4 & - & - \\
\hline 7 & Drill machine and pedestal grinder & 4 & - & - \\
\hline 8 & Discussion area & 1 & $3.6 \mathrm{~m} \times 7.1 \mathrm{~m}$ & $25.6 \mathrm{~m}^{2}$ \\
\hline 9 & Tables and chairs & 12 & - & - \\
\hline 10 & Flip charts & 2 & - & - \\
\hline 11 & 3-D manufacturing room & 1 & $3.6 \mathrm{~m} \times 7.1 \mathrm{~m}$ & $25.6 \mathrm{~m}^{2}$ \\
\hline 12 & 3-D printer & 2 & - & - \\
\hline 13 & Tables, chairs, and computer & 6 & - & - \\
\hline 14 & Storage area & 1 & $8.1 \mathrm{~m} \times 7.1 \mathrm{~m}$ & $57.5 \mathrm{~m}^{2}$ \\
\hline 15 & Tools crib & 6 & - & - \\
\hline 16 & Storage cabinet & 6 & - & - \\
\hline 17 & Storage shelves (floor-to-ceiling) & 1 & - & - \\
\hline 18 & Fire extinguishers & 8 & - & - \\
\hline
\end{tabular}

$-=$ not applicable, $m=$ meter, $m^{2}=$ square meter.

Source: Asian Development Bank. 


\section{B. TECHNICAL SPECIFICATIONS FOR THE WORKSHOP}

Table 20: Laboratory and/or Workshop for Industrial Project Laboratory

\section{Name of the Laboratory and/or Workshop INDUSTRIAL PROJECT LABORATORY \\ Proposed Student Enrollment Size \\ 20 \\ Applicable Field of Usage \\ MECHANICAL TECHNOLOGY; MECHATRONICS TECHNOLOGY}

\section{Parameter}

Size of Laboratory and/or Workshop

Electrical Loading

Requirement
Norm

Remarks

$\mathbf{2 3 . 7} \mathbf{m} \times \mathbf{1 5 . 3} \mathrm{m} \times \mathbf{6} \mathbf{m}$ (length $\times$ width $\times$ height $)$

3-phase power supply for conventional mill, turn, grinder

Each mill, turn, grind $15 \mathrm{KVA}$ and each machine assembly project station

2 KVA

Two 16A twin socket electrical outlet should be provided for each assembly

machine project station

$2016 \mathrm{~A}$ electrical socket outlet should be provided for general use in the

workshop, 6 in discussion room, 6 in 3-D printing room

All electrical installation should comply with local regulations

Three emergency stop-buttons should be provided

Floor Requirement Project work and storage area:

$12 \mathrm{KN}$

$300 \mathrm{~mm}$ concrete

2 coats epoxy industrial paint

Discussion and 3-D printing room

Raised floor at least $350 \mathrm{~kg} / \mathrm{m}^{2}$

Vinyl composition to reduce dust and improve electrical insulation

Lighting Requirement

(Lumen)

Standard ceiling flourescent lightings at $25 \mathrm{~W} / \mathrm{m}^{2}$

Emergency lights

Location of Laboratory and/or Workshop

(Floor)

Laboratory and/or

Workshop Climatic

Condition

Building Safety Code

Requirement

Door Width

Any floor

Air-conditioned

Comply with national safety code requirements

At least $1.5 \mathrm{~m}$ wide

First Aid Requirement

Storage Area

Requirement

Built-in Furniture

Adhering to building safety code

One storage room

Floor-to-ceiling shelves

Requirement

$\mathrm{A}=$ ampere, $\mathrm{D}=$ dimensional, $\mathrm{kg} / \mathrm{m}^{2}=$ kilogram per square meter, $\mathrm{KN}=$ kilonewton, $\mathrm{kVA}=$ kilo volt ampere, $\mathrm{m}=\mathrm{meter}, \mathrm{mm}=\mathrm{millimeter}$ $\mathrm{W} / \mathrm{m}^{2}=$ watt per square meter.

Source: Asian Development Bank. 


\title{
6.1.2 Standard Equipment List
}

\section{Table 21: Industrial Project Laboratory Equipment Specification}

\author{
Name of the Laboratory and/or Workshop INDUSTRIAL PROJECT WORKSHOP \\ Proposed Student Enrollment Size \\ 20 \\ Applicable Field of Usage: \\ MECHANICAL, MECHATRONIC, ELECTRICAL
}

\begin{tabular}{|c|c|c|c|c|}
\hline $\mathbf{S} / \mathbf{N}$ & Name of Item & Description of Item & Quantity & Remarks \\
\hline A & Training Equipm & 000.00 & & \\
\hline 1 & Machine Assemb & & 10 sets & \\
\hline
\end{tabular}

Workbench: (length $\times$ width $\times$ height) $1,800 \times 700 \times 825 \mathrm{~mm}$

Mechanical drive mechanism - Synchronous belt, chain, gear, rack, worm, crank, connecting rod, cam, groove wheel, friction wheel, ball screw and other transmission mechanism

Control system - Compact and portable hybrid measuring and testing system

Multiple-speed gearbox, dual 3-speed output, one output shaft with a positive function, at the top of the organic glass door. It mainly consists of box, gear, spline shaft, spacer sleeve, key, angular contact bearing, deep groove ball bearing, circlip, end cover, manual shift mechanism

2-dimensional worktable - Linear guide pair, ball screw pair, for installation and adjustment of related bearings, and application of related measuring tools

Decelerator: it mainly consists of spur gear, angular contact bearing, deep groove ball bearing, bracket, shaft, end cover, key

Intermittent rotary table four groove - Geneva mechanism, worm gear worm, friction wheel, thrust ball bearing, angular contact bearing, tabletop, bracket

Crank connecting rod and cam mechanism crank, connecting rod, cam, gear, rack, coupling, bearing seat, bearing, shield, guide rod, stay rod, rail

Simulation software for mechanical assembly and adjustment divided into 2 parts: manual assembly part and assembly video demonstration part

Three shaft gear decelerator - Spur gear, bevel gear, angular contact bearings, deep groove ball bearing, bracket, shaft, end cover, keys, right angle distributor of single bevel gear chain wheel, bevel gear and gear shaft three piece

Power supply, AC motor, speed regulator and power control box, to provide power source for mechanical system

Trainers' Training should be provided

\section{$2 \quad$ Fitter Workbench: $\$ 100,000.00$}

Workbench: (length $\times$ width $\times$ height) $1,500 \times 750 \times 800 \mathrm{~mm}$

20 units

Bench vise: 5 inch

20 units

Hacksaw

Circle file: 8-12 inch

20 units

Semi-circle file: $8-12$ inch

20 units

Square file: 8-12 inch

Diamond file: 8-12 inch

20 units

20 units

Angle file: 8-12 inch

20 units

Surface plare: $300 \times 400 \mathrm{~mm}$

20 units

Hammer

20 units

Try square

20 units

Steel rule: 150

20 units

20 units 
Table 21 continued

S/N Name of Item

\section{Description of Item}

Vernier caliper

Screw tape: M6, 8, 10, 12, 14

Monkey wrench: 10

Hacksaw blade

Straight screwdriver

Cross screwdriver

Tap wrench

Die wrench

Nipper plier

Wire brush

\section{Quantity Remarks}

20 units

20 units

20 units

50 units

20 units

20 units

20 units

20 units

20 units

20 units

$3 \quad$ Lathe Machine with Digital Display

2 units

Travel Range

Swing over bed range: $450-470 \mathrm{~mm}$

Swing over cross slide: $280-300 \mathrm{~mm}$

Distance between center: $1,500 \mathrm{~mm}$

Tailstock travel: 150-170 mm

Tailstock spindle taper: MT no.4

Feed specification:

Longitudinal feed ( $Z$ axis): $0.06-0.88 \mathrm{~mm} / \mathrm{rev}$

Cross feed (X axis): 0.03-0.44 mm/rev

Feed motor (X / Z axes): $1.5 \mathrm{~kW}$ or more

\begin{tabular}{|c|c|c|c|}
\hline \multirow[t]{2}{*}{4} & \multicolumn{2}{|c|}{$\begin{array}{l}\text { Vertical Milling Machine with Digital Display } \\
\text { General Specifications (minimum requirements): } \$ 60,000.00\end{array}$} & 2 units \\
\hline & Travel Range & $\begin{array}{l}\text { X axis, table: } 750 \mathrm{~mm} \\
\text { Y axis, cross: } 380 \mathrm{~mm} \\
\text { Z axis, vertical knee travel: } 380 \mathrm{~mm}\end{array}$ & \\
\hline & $\begin{array}{l}\text { Table } \\
\text { Specification }\end{array}$ & $\begin{array}{l}\text { Table size: } 1.300 \times 300 \mathrm{~mm} \\
\text { Table loading: } 200 \mathrm{~kg} \\
\text { T slot: } 16 \mathrm{~mm}\end{array}$ & \\
\hline & $\begin{array}{l}\text { Ram } \\
\text { Specification }\end{array}$ & $\begin{array}{l}\text { Ram travel: } 500-600 \mathrm{~mm} \\
\text { Ram swivel: } 360^{\circ}\end{array}$ & \\
\hline & $\begin{array}{l}\text { Spindle } \\
\text { Specification }\end{array}$ & $\begin{array}{l}\text { Spindle power: } 3.75 \mathrm{~kW} \\
\text { Spindle speed: } 3,500 \mathrm{rpm} \\
\text { Spindle taper: NT } 40 \\
\text { Quill travel: } 140 \mathrm{~mm} \\
\text { Quill auto feed: } 0.035,0.07,0.14 \\
\text { Head tilt: }+/-45^{\circ}\end{array}$ & \\
\hline & \multicolumn{3}{|c|}{ Engineering Specification } \\
\hline & & $\begin{array}{l}\text { Power draw bar } \\
\text { Digital display } \\
\text { Chip pan } \\
\text { Hardened and ground guide with turcite } \\
\text { Centralized auto-way } \\
\text { Lubricant } \\
\text { X and Y axes power feed } \\
\text { Transformer with sufficient length of cable and terminal lugs }\end{array}$ & \\
\hline \multirow[t]{4}{*}{5} & \multicolumn{2}{|c|}{$\begin{array}{l}\text { Surface Grinding Machine with Digital Display } \\
\text { General Specifications (minimum requirements): } \$ 50,000.00\end{array}$} & 2 units \\
\hline & Travel Range & $\begin{array}{l}X \text { axis (longitudinal): } 500-600 \mathrm{~mm} \\
\text { Y axis (crosswise): } 200-220 \mathrm{~mm} \\
\text { Max grinding area: } 500 \times 100 \mathrm{~mm}\end{array}$ & \\
\hline & $\begin{array}{l}\text { Table } \\
\text { Specification }\end{array}$ & $\begin{array}{l}\text { Size: } 200 \times 500 \mathrm{~mm} \\
\text { Longitudinal feed rate: } 0.1-20 \mathrm{~m} / \mathrm{min} \\
\text { Maximum table loading: } 100 \mathrm{~kg}\end{array}$ & \\
\hline & Hydraulic Pump & $0.75 \mathrm{~kW}(\mathrm{~min})$ & \\
\hline
\end{tabular}


Table 21 continued

\begin{tabular}{|c|c|c|}
\hline $\mathbf{S} / \mathbf{N}$ & Name of Item & Description of Item \\
\hline & Spindle Motor & $\begin{array}{l}\text { Speed: } 50 \mathrm{~Hz} / 2,850 \mathrm{rpm} \\
\text { Power: } 2 \mathrm{HP} / 1.5 \mathrm{~kW}\end{array}$ \\
\hline & $\begin{array}{l}\text { Standard } \\
\text { Grinding Wheel }\end{array}$ & Wheel size: $205 \mathrm{~mm}$ (diameter) $\times 6 \mathrm{~mm}($ width $) \times 31.75 \mathrm{~mm}$ (bore) \\
\hline & $\begin{array}{l}\text { Engineering } \\
\text { Specification }\end{array}$ & $\begin{array}{l}\text { Longitudinal auto feed } \\
\text { Grinding wheel balancer devices } \\
\text { Magnetic chuck-permanent type } \\
\text { AC Servo motor for vertical rapid feed } \\
\text { V-V slide way design complete with coolant tank }\end{array}$ \\
\hline
\end{tabular}

6 Bench Grinder: $\$ 1,400.00$ $1.5 \mathrm{~kW}$, Voltage 220, Wheel Size: $200 \times 25 \times 32 \mathrm{~mm}$

7 3-D Printer: $\$ 9,000.00$

Printer and

Printing

Properties
Technology: Fused filament fabrication

Print head: Dual nozzle, with lifting mechanism on 2nd nozzle

Easily swappable print cores

Build volume: Left nozzle: $215 \times 215 \times 200 \mathrm{~mm}$

Right nozzle: $215 \times 215 \times 200 \mathrm{~mm}$

Dual material: $197 \times 215 \times 200 \mathrm{~mm}$

Filament diameter: $2.85 \mathrm{~mm}$

Layer resolution: $0.4 \mathrm{~mm}$

Nozzle: 20-200 micron

Step accuracy X, Y, Z: 12.5, 12.5, 2.5 micron

Print head travel speed: $30-300 \mathrm{~mm} / \mathrm{s}$

Material flow speed: 0.40: up to $16 \mathrm{~mm}^{3} / \mathrm{s}$

Build plate: Heated glass bed

Material types: PLA, PVA, ABS, CPE, nylon

Nozzle diameter: $0.4 \mathrm{~mm}$

Nozzle temperature: $180-280^{\circ} \mathrm{C}$

Build plate temperature: $20-100^{\circ} \mathrm{C}$

Nozzle heat up time: $<2$ min

Build plate heat-up time: $<4 \min \left(20->60^{\circ} \mathrm{C}\right)$

Average operation noise: $50 \mathrm{dBA}$

Nozzle replacement: Easily swappable print cores

Filament storage: Open, reel holder including guide for 2 spools of $750 \mathrm{~g}$

NFC system to automatically detect material type

Connectivity: $\mathrm{Wi}-\mathrm{Fi}$, ethernet, stand-alone via USB-drive

Bed levelling: Active leveling

Camera: Yes

Input: 100-240V, 4 A, 50-60 Hz, $221 \mathrm{~W}$ maximum

Output: 24 V DC, $9.2 \mathrm{~A}$

Software:

File types: Print direct from Cura via network, stand-alone

File transfer: USB drive printing

$\begin{array}{cl}\text { Latest Version } & \text { i-7 Processor or higher } \\ \text { of Personal } & \text { 16 GB RAM } \\ \text { Computer } & \text { 1TB HDD } \\ & \text { Video Card latest specification } \\ & \text { Latest version OS } \\ & \text { MS Office Suite }\end{array}$

Network Printer
4 units

2 units

\section{Quantity Remarks}

- 
Table 21 continued

S/N Name of Item

B Tools and Accessories

1 Machine Assembly Project

\section{$2 \quad$ Milling}

Stub Milling

Arbor

Collet Chuck

Conical Type

Collet for

Chuck Holders

\section{Assemblya}

lamar and copper. The kit is mainly consisted of the toolbox, inner six

angle wrench, spanner, adjustable wrench, file, compasses, hammer,

die, die frame, screwdriver, and pliers

Measuring instrument: consists of vernier caliper, universal angle ruler, square, dial gauge, and micro-meter

Diameter $\times$ length: $16 \times 25 \mathrm{~mm}$

Diameter $\times$ length: $22 \times 25 \mathrm{~mm}$

Diameter $\times$ length: $27 \times 25 \mathrm{~mm}$

Diameter $\times$ length: $32 \times 25 \mathrm{~mm}$

Diameter: $5 \mathrm{~mm}$

Diameter: $6 \mathrm{~mm}$

Diameter: $8 \mathrm{~mm}$
10 sets

10 sets

\section{Quantity Remarks}

2 units

2 units

2 units

2 units

2 units

2 units

2 units

2 units

Diameter: $12 \mathrm{~mm}$

2 units

Diameter: $16 \mathrm{~mm}$

2 units

Diameter: $20 \mathrm{~mm}$

2 units

Drill Chuck

2 units

Wrench for

Chuck Holder

Fixture for

2 units

2 units

der Clamp

or Unclamp

Parallel Bar

Parallel bar size: $5 \times 10 \times 100 \mathrm{~mm}$

4 units

Parallel bar size: $10 \times 20 \times 150 \mathrm{~mm}$

4 units

Parallel bar size: $15 \times 30 \times 150 \mathrm{~mm}$

4 units

Parallel bar size: $20 \times 40 \times 200 \mathrm{~mm}$

4 units

Rotary Table

Hydraulic Vice

Diameter: $300 \mathrm{~mm}$ complete with mounting accessories

2 units

Swivel Base

Jaw width: $100 \mathrm{~mm}$ complete with mounting accessories

2 units

Hydraulic Vice

Swivel, Tilt,

Jaw width: $100 \mathrm{~mm}$ complete with mounting accessories

2 units and Swivel

Cutting Tools

Angular cutter: $90^{\circ}$ double equal angle

2 units

Twist drill: $1-13 \mathrm{~mm}$ diameter

2 units

Twist drill: 13.5-23 mm diameter

2 units

End mills diameter: $50 \mathrm{~mm}$

2 units

Face mill diameter: $50 \mathrm{~mm}$

Gear cutter, pressure angle: $20^{\circ}$, module 3 reamer (taper shank)

2 units

Taper shank: 3-14 mm diameter in steps of $1 \mathrm{~mm}$

2 units

Shell end mill diameter: $50 \mathrm{~mm}$

2 units

Sitting saw diameter: $1.25-3 \mathrm{~mm}$

2 units

Slot drills diameter: $3-20 \mathrm{~mm}$

2 units

Diameter $25 \mathrm{~mm}$

T-slot cutter diameter $22 \times 8 \mathrm{~mm}$

4 units

Splash Guard

Front and rear

2 units 
Table 21 continued

\section{S/N Name of Item}

\section{3} Grinding Machine

Wheel Balancing Complete with accessories Unit

Creep Feed For steel roughing and finishing

2 units

Grinding Wheel

Machine Vices Opening: $80 \mathrm{~mm} \quad 2$ units

Permanent 2 units

Magnet Table

Compound Opening: $60 \mathrm{~mm} \quad 2$ units

Angle Vice

Cleaning Tower

with Stand

Tower Rolls

2 units

Grinding Wheels

Sine Plate

2 units

2 units

Magnetic type $-10\left(L=170, B=100\right.$, angle adjust up to $\left.60^{\circ}\right)$

2 units

Non-magnetic type - 5

2 units

Surface Grinder

2 units

Dresser

Bench Work Bench vice with jaw width: $150 \mathrm{~mm}$, approximately 2 units

Tools

\section{$4 \quad$ Lathe}

Boring Bar

\begin{tabular}{|c|c|c|}
\hline Boring Bar & $\begin{array}{l}\text { Boring bar for } 3 \mathrm{~mm} \text { square: } \mathrm{HSS} \text { tool bit } \\
\text { Boring bar for } 6 \mathrm{~mm} \text { square: HSS tool bit } \\
\text { Boring bar for carbide inserts }\end{array}$ & $\begin{array}{l}2 \text { units } \\
2 \text { units } \\
2 \text { units }\end{array}$ \\
\hline Dog Carriers & Range $10-50 \mathrm{~mm}$ & 2 un \\
\hline \multicolumn{2}{|l|}{ Driving Plate } & 2 un \\
\hline Center & $\begin{array}{l}\text { Dead center } \\
\text { Live center } \\
\text { Revolving center } \\
\text { Half center }\end{array}$ & $\begin{array}{l}2 \text { units } \\
2 \text { units } \\
2 \text { units } \\
2 \text { units }\end{array}$ \\
\hline Chuck & $\begin{array}{l}\text { Drill chuck, keyless - clamping range up to } 13 \mathrm{~mm} \text { diameter } \\
\text { Four-jaw chuck } \\
\text { Three-jaw self-centering chuck }\end{array}$ & $\begin{array}{l}2 \text { units } \\
2 \text { units } \\
2 \text { units }\end{array}$ \\
\hline \multicolumn{2}{|l|}{ Chuck Guard } & 2 uni \\
\hline Splash Guard & Front and rear & 2 un \\
\hline Set of Collets & $\begin{array}{l}15 \text { pieces ( } 5 \mathrm{~mm} \text { to } 20 \mathrm{~mm} \text { in step of } 1 \mathrm{~mm} \text { ) } \\
\text { Collet holders }\end{array}$ & $\begin{array}{l}2 \text { units } \\
2 \text { units }\end{array}$ \\
\hline Knurling Tool & $\begin{array}{l}\text { Self-centering with } 3 \text { grades of diamond knurl } \\
\text { Straight knurl }\end{array}$ & $\begin{array}{l}2 \text { uni } \\
2 \text { un }\end{array}$ \\
\hline \multicolumn{2}{|l|}{ Test Bar } & 2 un \\
\hline Tool Holder & $\begin{array}{l}\text { Straight turning tool holder } \\
\text { Right-hand turning tool holder } \\
\text { Left-hand turning tool holder } \\
\text { Inserts turning tool holder } \\
\text { Parting off tool holder }\end{array}$ & 2 un \\
\hline $\begin{array}{l}\text { Quick Change } \\
\text { Tool Post }\end{array}$ & 4-way & $2 u$ \\
\hline
\end{tabular}


Table 21 continued

\begin{tabular}{|c|c|c|c|c|}
\hline $\mathbf{S} / \mathbf{N}$ & Name of Item & Description of Item & Quantity & Remarks \\
\hline 5 & \multicolumn{2}{|c|}{ Pedestal Grinder with Grinding Wheel: Diameter 200 mm, Approximately } & 2 units & \\
\hline \multirow[t]{7}{*}{6} & \multicolumn{3}{|c|}{ Bench Drilling Machine } & \\
\hline & Specification & $\begin{array}{l}\text { Minimum capacity: } 13 \mathrm{~mm} \text { diameter } \\
\text { Table size: } 240 \times 240 \mathrm{~mm} \text {, approximately }\end{array}$ & 4 units & \\
\hline & Drill & $\begin{array}{l}\text { Twist drill: } 1-13 \mathrm{~mm} \text { diameter in steps of } 0.5 \mathrm{~mm} \\
\text { Twist drill: } 13-23 \mathrm{~mm} \text { diameter in steps of } 0.5 \mathrm{~mm}\end{array}$ & $\begin{array}{l}2 \text { units } \\
2 \text { units }\end{array}$ & \\
\hline & Drill Sleeve & $\begin{array}{l}\text { MT 1-2 } \\
\text { MT 1-3 } \\
\text { MT 2-3 }\end{array}$ & $\begin{array}{l}2 \text { units } \\
2 \text { units } \\
2 \text { units }\end{array}$ & \\
\hline & $\begin{array}{l}\text { Reamer Taper } \\
\text { Shank }\end{array}$ & & 2 units & \\
\hline & Mandrel & $16-30 \mathrm{~mm}$ diameter & 2 units & \\
\hline & Workbench Tools & Bench vise with jaw: width $150 \mathrm{~mm}$, approximately & 2 units & \\
\hline \multirow[t]{5}{*}{ C } & \multicolumn{2}{|c|}{ Furniture: Table and Chair Sets } & 12 units & \\
\hline & & Teacher's table and chair set & 1 set & \\
\hline & & Storage shelf & 1 unit & \\
\hline & & Storage cabinet & 6 units & \\
\hline & & Flip chart & 2 units & \\
\hline
\end{tabular}

$\mathrm{A}=$ ampere $\mathrm{ABS}=$ acrylonitrile butadiene styrene, $\mathrm{AC}=$ alternating current, $\mathrm{B}=$ breadth $,{ }^{\circ} \mathrm{C}=\mathrm{Celsius}, \mathrm{CPE}=$ chlorinated polyethylene, $\mathrm{dBA}=\mathrm{a}$-weighted decibels, $\mathrm{g}=$ gram, $\mathrm{GB}=$ gigabyte, $\mathrm{HDD}=$ hard disk drive, $\mathrm{HP}=$ horsepower, $\mathrm{HSS}=$ high speed steel, $\mathrm{Hz}=\mathrm{Hertz}, \mathrm{kg}=\mathrm{kilogram}$, $\mathrm{kW}=$ kilowatt, $\mathrm{L}=$ length, $\mathrm{m}=$ meter, $\mathrm{M}=$ metric, $\mathrm{mm}=$ millimeter, $\mathrm{mm} / \mathrm{s}=$ millimeter per second, $\mathrm{mm}^{3} / \mathrm{s}=$ cubic millimeter per second, MS = Microsoft,$M T=$ Morse taper, NT = National Machine Tool Builder Association, OS = operating system, PLA = polylactic acid, $\mathrm{PVA}=$ polyvinyl acetate, $\mathrm{rpm}=$ revolution per minute, $\mathrm{TB}=$ terabyte, $\mathrm{V}=$ volt, $\mathrm{VDC}=$ voltage direct current, $\mathrm{W}=$ watts.

Source: Asian Development Bank. 


\subsubsection{Sample Photos for Industrial Project Laboratory}

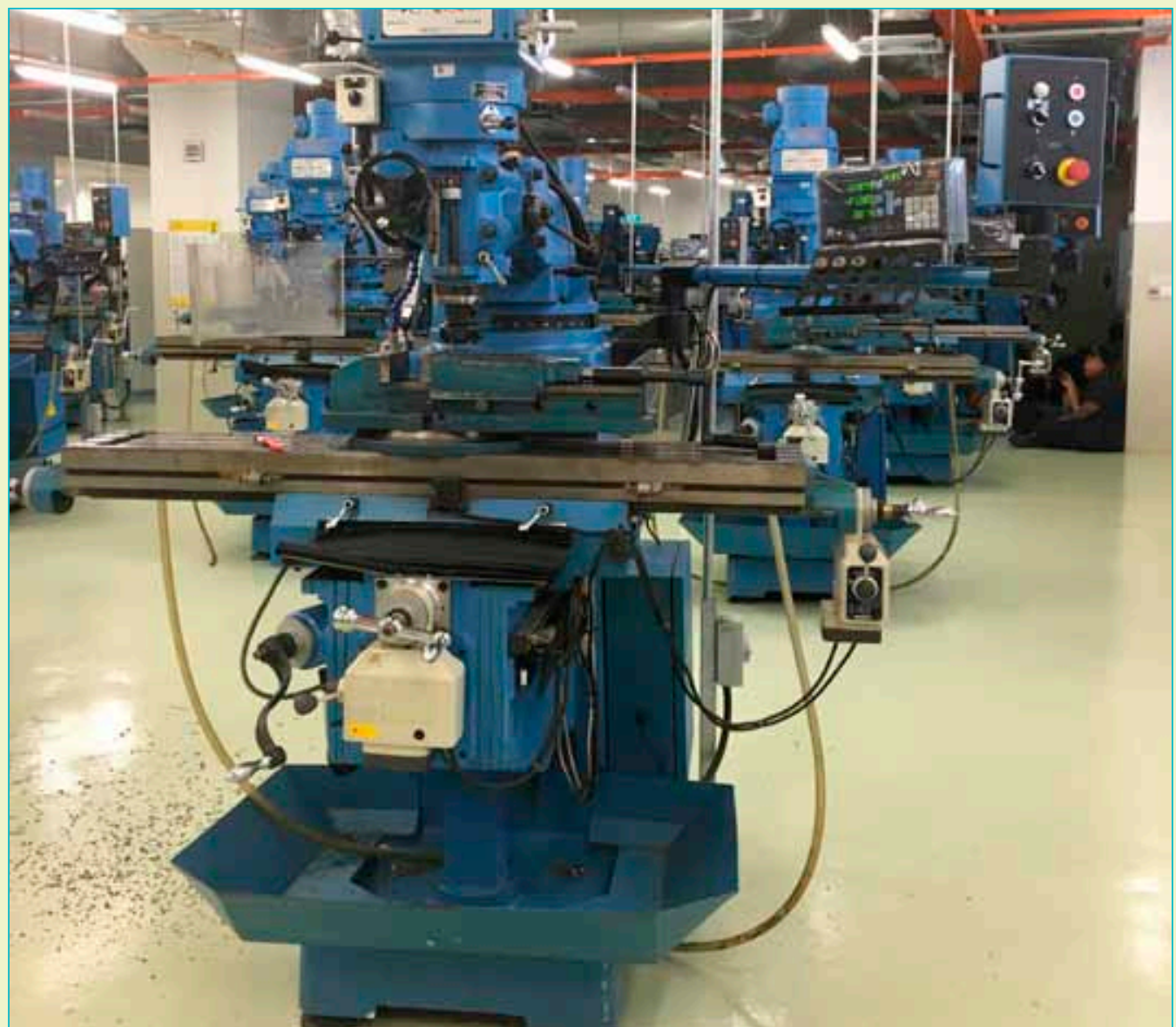

Conventional milling machine. Set-up in a conventional milling workshop.

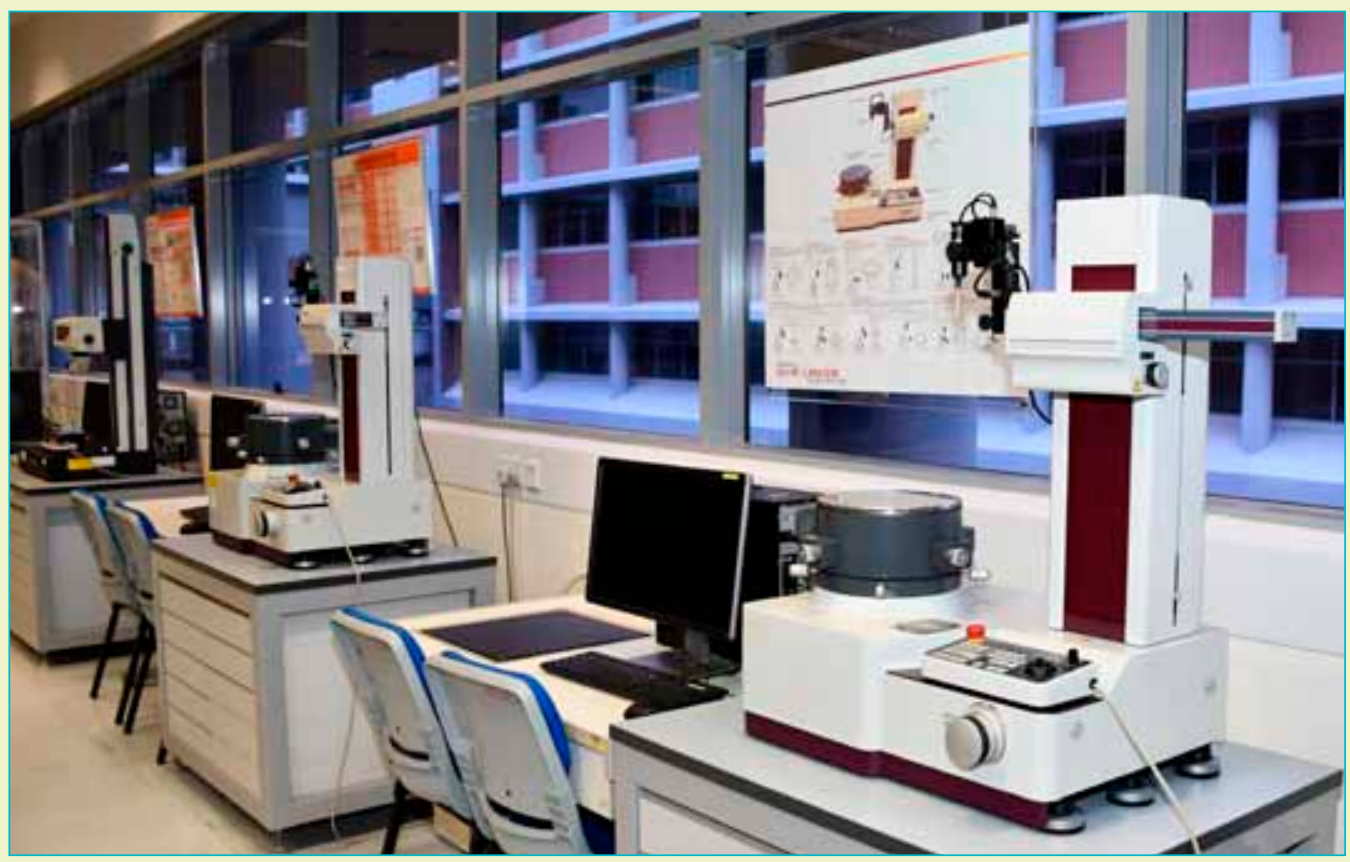

Metrology station. Metrology machine for student use. 


\section{REFERENCES}

Drummey Rosane Anderson, Inc., J. Macaluso, D. J. Lewek, and B. C. Murphy. 2004. Building and Renovating Schools: Design, Construction Management, Cost Control. Rockland: RSMeans.

International Labour Organization. 1978. Environment Planning Guide for Vocational and Technical Training and Education Programmes. Refrigeration and Air Conditioning. Geneva.

1986. Environment Planning Guide for Vocational and Technical Training and Education Programmes. Learning Stations and Layouts for Workshops. Part 1: Machining/Fitting, Tool and Die Making, Sheet Metal, Automotive, Plumbing/Pipe Fitting, Carpentry/Joinery, Masonry, Refrigeration/Airconditioning. Geneva.

National Institute of Building Sciences. 2017. Training Facility. https://www.wbdg.org/building-types/ education-facilities/training-facility (accessed 4 October 2019).

Pitanilabut, A. 1979. Guideline for Planning of Facilities for Technical and Vocational Education. Bangkok: UNESCO Regional Office for Education in Asia and Oceania.

Schwab, K. 2016. The Fourth Industrial Revolution. Geneva: World Economic Forum.

Tanner, C.K. and J. A. Lackney. 2006. Educational Facilities Planning: Leadership, Architect, and Management. London: Pearson.

United Nations Educational, Scientific and Cultural Organization (UNESCO). 1979. Prototype Workshops and Laboratories for Technical Education and Vocational Education. Part 1: Proposed Planning Methods. Paris. 1989. UNESCO's Educational Buildings and Furniture Programme. Newsletter. Paris. 


\section{Training Facility Norms and Standard Equipment Lists Volume 2-Mechatronics Technology}

This publication aims to support good practice in establishing facilities for mechatronics technology training programs. It covers equipment specifications aligned with current industry standards.

This volume is the second of four technical specification reference guides on training facility norms and standard equipment lists. Designed for technical and vocational education and training practitioners and policymakers, the series covers the following strategic manufacturing trades: (i) precision engineering or machining, (ii) mechatronics technology, (iii) mechanical technology, and (iv) electrical technology.

\section{About the Asian Development Bank}

ADB is committed to achieving a prosperous, inclusive, resilient, and sustainable Asia and the Pacific, while sustaining its efforts to eradicate extreme poverty. Established in 1966, it is owned by 68 members -49 from the region. Its main instruments for helping its developing member countries are policy dialogue, loans, equity investments, guarantees, grants, and technical assistance. 